\title{
PSYCHOLOGY OF ARTS: CONTEMPORARY MUSICOLOGICAL PROJECTIONS
}

\author{
Monograph
}

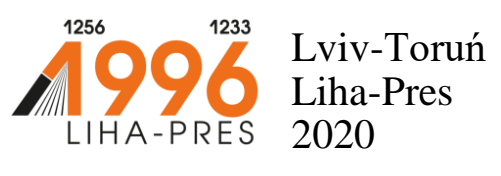




\section{Reviewers:}

Prof. nadzw., dr hab. Stanistaw Kunikowski, Rektor of Cuiavian University in Wloclawek (Republic of Poland);

Prof. $d r$ hab. Kazimierz Pierzchata, Katolicki Uniwersytet Lubelski/Catholic University of Lublin (Republic of Poland);

Prof. dr hab. Stanistaw Juszczyk, Uniwersytet Ślaski / University of Silesia (Republic of Poland).

\section{Author:}

Samoilenko A. I., Doctor of Arts, Professor, Vice-rector for Scientific Work, Odessa National A. V. Nezhdanova Academy of Music.

\section{Samoilenko A.}

Psychology of arts: contemporary musicological projections : monograph / Alexandra Samoilenko. - Lviv-Toruń : Liha-Pres, 2020. $144 \mathrm{p}$.

ISBN 978-966-397-202-2

DOI https://doi.org/10.36059/978-966-397-202-2

Liha-Pres is an international publishing house which belongs to the category "C" according to the classification of Research School for Socio-Economic and Natural Sciences of the Environment (SENSE) [isn: 3943, 1705, 1704, 1703, 1702, 1701; prefixMetCode: 978966397]. Official website www.sense.nl. 


\section{CONTENTS}

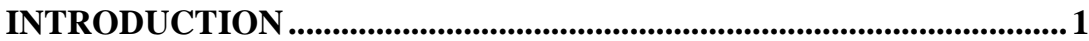

\section{SECTION 1}

METHODICAL INTERACTIONS OF MUSICOLOGY

AND PSYCHOLOGY OF ARTS .........................................................8

1.1. Psychological prerequisites for art analysis:

considerations about the method .........................................................8

1.2. Cognitive attitudes of modern musicology

as methodical factors of psychology of arts............................................20

1.3. Musicological perspectives of «psychology of arts»

by L. S. Vygotsky..........................................................................................33

1.4. Psychological foundations of musical thinking and semantic principles of musical language ........................................47

\section{SECTION 2}

\section{LEADING CATEGORIES OF PSYCHOLOGY}

OF MUSICAL ARTS.

2.1. The category of spirituality and the concept of artefact in the psychology of arts: the musicological aspect

2.2. Interdisciplinary tendencies of modern musicology and the noological conceptual sphere

2.3. Tragic cognition and catharsis: from aestheti and psychological analysis to musical theory

2.4. Time category and psychological aspects of musical temporality

CONCLUSIONS

SUMMARY.

REFERENCES 


\section{INTRODUCTION}

Contemporary musicology exists in the complex human world and in the equally complex, oversaturated world of musical art. Playing and organizing at the new cognitive level the matter of music, it acquires the ability to discover and study the most essential aspects of human being, the most important laws of human nature - its constancy and dynamic existential qualities. Due to this, musicology is one of the first in the humanities today, dedicated to revealing the phenomenon of the semantic precedent of human consciousness and human life. But it also forces musicologists to deepen their psychological foundations, perspectives in the field of art, engage in active interaction not only with the artistic phenomena and the semantic world of culture, but also with related humanities. Moreover, it turns out that for some of them musicologists are able to perform prognostic and evidential systemological functions, that means, to open new horizons of cognition, ordering and testing their own material cognitive and assessment experience. Thus, modern musicology is capable of such methodical and categorical interaction with the psychology of arts, which forms new, systematically organized, that is, substantially holistic, cognitive projections.

We understand the word «projection» in its two possible meanings: how to construct a volume dimensional figure capable of bringing out, explicating the accumulated experience of cognition; as a specific internal refraction - the transformation of certain parameters, tasks of the surrounding reality, the objectivation of significant thinking positions, assessment approaches for this cognition sphere. And let's try to explain why psychology of arts is becoming a necessary conceptual base of musicological discourse today.

The importance of psychological knowledge and the recognized social positions of psychological disciplines do not eliminate the significant methodological obstacles, unresolved problems that exist in the development of modern psychological science, especially in those sections that are related to the study of human behavior and consciousness. From ancient times, certain unpredictable personality in the vicissitudes of life, the paradoxality of human existence attracted the attention of thinkers and artists, and the latter managed 
to reflect the complexity of the inner world - the psychological essence of man in the most complete, convincing and understandable form. It is the art with its systematic artistic and symbolic resources that becomes a mirror of human consciousness, and hence a guide to the secrets of human existence.

Throughout the XX century, the experience of art and its accumulated material have been widely used by philosophical theories and psychological practices: the coordination of a generalized philosophical approach with psychological empiricism takes place in the direction of transpersonal humanistic psychology, which becomes one of the fundamental human sciences. However, the fundamental questions that are not completely resolved by any of the known branches of the humanities remain questions about the nature, ways of existence, structural and semantic qualities of human consciousness, which also requires consideration of two its historical forms - community-collective and individual-personal. The phenomenon of consciousness forms one of the central subjects of philosophy, psychology and art history in connection with the meaningful activity of man, which reinforces the importance of sensory culture, brings the problem of experience to the first level of interdisciplinary theories.

The psychology of arts is born at the intersection of general humanitarian and natural sciences, expresses their mutual methodological interest, while pointing to new methodological possibilities of the arts cognition, as well as its new theoretical tasks. The implicit period of the existence of this scientific and subject area is related to the evolution of both the disciplines of arts, and the development of aesthetic science and its interaction with psychological systems. For the recent explicit, firstly, incorporating philosophical aesthetics into the content is significant; secondly, the multiplicity of author's interpretations and attempts to construct a theoretical system; thirdly, the gradual revival and placement of the scientific poetics of L. Vygotsky in the central place, orientation to the positions and concepts of Vygotsky, expressed not only in the «Psychology of Arts», but also in the whole set of scientific works. The leading direction of the psychology of arts, initiated by L. Vygotsky, today remains the theory of artistic (aesthetic) emotions in unity with the doctrine of the cathartic foundations of the artistic 
form, consistent with the main for the scientist theory of human consciousness (in the synthesis of psychology of consciousness and psychology of activity).

The most relevant and scientifically and methodologically balanced on the modern humanitarian context and cognitive system of musicology is the separation of three components of psychology of arts: psychology of consciousness, psychology of creative process, which includes psychology of artistic creativity, and psychology of artistic thinking (with priority position of musical thinking). Psychological theory of consciousness requires, first of all, the definition of criteria and methods of assessing human consciousness, explaining the descriptive language of psychological phenomena, the formation of basic understandable terms, the creation of a relevant subject of discursive field. It develops the direction of symbolization - allegorical exteriorization - the psychological content of man in his integrity. The study of the creative process, including its artistic forms, is most of all due to the theory of signification, which is part of L. Vygotsky's doctrine of higher psychic functions. Accordingly, the psychology of the creative process is directed to the sign activity of man, revealing his dependence on the semantic tasks and needs, and most of all on those that are "crowning" and completing all common semantic human efforts, represent humanity as the only evolutionary organism (from the top noetic senses).

The third component of the psychology of arts contributes to the discovery of the laws of consciousness, the process of thinking and experiencing, in particular, the identification of the special role of musical reflections-images and temporal process of musical communication in the artistic form. This trend allows us to offer typology of musical forms in the context of emotionology, to reveal the distinctness of interpretive approaches in music and to music, to explain the peculiarities of musical language with its "growing logos», which indicates the close connection between the musical and the unconscious, that is, the rootedness of music in the deep memory.

The main approach, which combines all areas of the psychology of the arts, is noetic in its specific psychological comprehension (understanding), but with appeal to the phenomenological philosophical concept (in particular E. Husserl, G. Spet, A. Losev). 
Higher noetic categories, defined as memory, play and love, correspond to higher universal semantic instances of culture; organize transitive conceptual and methodical interactions between sections of psychology of arts. The noetic modus of psychology of consciousness is explained by the fact that the key is the phenomenon and concept of memory, both in the collective and individually-personal forms; a psychology of creativity consistent with a cognitive approach makes key the phenomenon play; for artistic concepts, in their psychological equivalent, the expression of the communicative calling of man as a «calling to communication» (S. Averintsev) is the feeling and state of love, of a higher positive resonance with the holistic world. All noetic syntagms have symbolic properties, are unique to all, without exception, spheres of human activity; so, they pass through all spheres, all historical stages of development of these spheres, become the most general valuable universals, assume even their seniority in relation to human culture (remember: «God is love», or, according to J. Huizinga, "a play older than culture").

In the context of the noetic approach there can be developed the theory of self-actualization by A. Maslow, the theory of «personal senses» by A. Leontiev, the action psychology by V. Roments; this way leads to the formation of a large branch called «psychology of personality», which interests researchers with its creativity, that is, to a kind of «creative psychology». In addition, the key issue in this area is the «language of consciousness» (it means, ways and forms of awareness - rationalization), including the meaning of the process of verbalization, words as a sign form, in general about semiotic functions and the semantic structure of consciousness, empathy and catharsis. The main thing for this approach is the recognition of the active formative role of the individual personal consciousness, which can «see» and assess itself only by creating separate, «external» subjects-signs, which become «artificial instruments» of consciousness, «psychological tools» (in terms of L. Vygotsky).

The modern concept of a noological approach to the study of the process of musical thinking inevitably links A. Losev's theory about the «thing» and the material construction of the world, his views on the logos and ethos - the origins of the mind in man and the human in the mind, with the doctrine of experience, the subject-sensual content 
of consciousness, the noesis addressing of human personal meanings and the noematic conditionality of the artistic object.

Phenomenological experience is precisely in the attachment of transcendental definitions to the reality of human consciousness as it is through experience, the content of which is not translated into certain verbal and conceptual forms. The components of the noological system on which musical thinking is based, presuppose continual connections between the logos - the mind - the comprehension - the ethos - the worldview - the essence (the entelechy) - the meaning - the thing - the reality - the sensual comprehension - the «feeling intelligence» - the imaginative models - the form - the finishing semiosis.

Modeling concepts in different cognitive systems are:

- in A. Losev's doctrine about musical logic: space - chaos; vitality - death, decay; movement and expediency, number as quantity and quality; time and rhythm;

- in the meaning coordinates of E. Husserl: it is experience, intention, consciousness, reality, the noematic and noesis;

- the key antinomy of J. Huizinga's theory is: the normative order is the beauty that is achieved in free play and acquires the status of aesthetic.

A musicological thought that measures reality by means of musical creativity produces own paired opposition, forming, as a coordinate system, a historical and theoretical paradigm. Thus, in historical musicology, order is a temporal correspondence to the meaning of life - the meaning of creativity with the help of the idea (image) of a person as beautiful (perfect). In theoretical musicology, order is the temporal correspondence of an image (plan) to the form of its embodiment (harmony of correspondence).

Psychological foundations of musicological knowledge (knowledge of music) are also motivated by a complex dialogue between historical and personal-psychological times. The human in history corresponds in one way or another to the historical in man, and in human creativity there is an intentional integrity of the «pure» mind, not clouded by the manifestations of a flowing habitual consciousness, aimed at the ideal as the most useful, pragmatically 
advantageous. R. Eucken ${ }^{1}$ called this «beneficial» orientation as «activism,» that is, a manifestation of selective reasonable activity. The ideal, the perfect reflects the social choice that is appropriate for the subject insofar as it represents the universal meaning experience of culture. This experience can be transformed into personal semantic positions, so it is likely that the reverse application of V. Frankl's noetic formula that the unique meaning of today becomes the universal meaning tomorrow... 2

The subjective and psychological phenomenon of meaning-setting, which is a purely human property, leads to the definition of symbolic forms, which will bring us to the mechanism of activity of consciousness as close as possible, and through it - to higher creative instances, even to the divine ones. Thus, there arises the interdependence between these instances and the artistic and communicative forms, and a new conceptualization of cultural reality, based on the categorization of sensual-thinking reality (as conscious reality) takes place.

The noetic conception of consciousness, as well as the identification of the noetic projections of the artistic image, allows us to work out ways to solve the problem of the unconscious, which is recognized as crucial to the psychology of consciousness, and therefore fundamental to the psychology of arts. It is the theoretical basis and the main methodological prerequisite for all forms of psychological knowledge because, in L. Vygotsky's words, "the unconscious is potentially conscious"; as a result, the highly debatable and limited by the psychotherapeutic approach theory of S. Freud does not lose its value. To quote L. Vygotsky: "The unconscious is not separated from consciousness by any impassable wall. The processes that begin in it often have their continuation in the consciousness, and, conversely, much of the conscious is displaced by us into the subconscious sphere. There is a constant, never-ending, live dynamic connection between the two spheres of our consciousness. The unconscious influences our actions, manifests

1 Эйкен Р. Смысл и ценность жизни. Пер. с нем. М. М. Тареева. М.: ЭЛИАAPTO, 2008.

2 Франкл В. Человек в поисках смысла: Пер. с англ. и нем. Bступ. cm. А. Леонтьева. М.: Прогресс, 1990 
itself in our behavior, and through these traces and manifestations we learn to recognize the unconscious and the laws that rule it» ${ }^{3}$.

The process of awareness as a constant transition from the sensual reserves of the unconscious (deep memory) to conscious thinking forms (rational thinking and operational memory) is the primary and the main material of musical art; and it is music that is a special «language of consciousness», agreed with all the contradictions and difficulties of the latter, and in this capacity - a special kind of sign activity of the person. Thus, there arises a particular musicological (musical and artistic) contextual circle of the concept consideration of catharsis by L. Vygotsky that also requires a new look at the psychology of arts - as a discipline, which involves the inclusion of musical and semiological analysis at all its subject levels and in all kinds of artistic forms, including the comparative discussion of cognitive processes occurring in art.

The following sections of the monograph suggest consistent explanations of musicological issues related to innovative methodical tendencies and the main categorical «nodes» of contemporary psychology of arts.

\footnotetext{
${ }^{3}$ Выготский Л. Психология искусства. М.: Искусство, 1968. С. 94
} 


\section{SECTION 1 \\ METHODICAL INTERACTIONS OF MUSICOLOGY \\ AND PSYCHOLOGY OF ARTS}

\subsection{Psychological prerequisites for art analysis: considerations about the method}

Turning to the question of the role of psychological knowledge in the modern world and the psychological aspects of musicology as a certain cognitive field of art, we can see that in recent years, the projections of L. Vygotsky's works to the theoretical platform of humanitarian thought have clearly increased and even were determined for the first time. However, this happens not so much in the works of domestic authors, but as foreign - American, English, first of all, psychologists, linguists, semiotics, specialists in philosophy of language, some others. Today, Vygotsky's theory is perceived as a necessary psychological component of general humanitarian concepts of man, the solution of issues of human existence in the world, that is, its existential problems. This word existential - is quite often found on the pages of psychological and musicological studies of the second half of the XX century, and beyond the «eschatological» meaning, which it acquired in the philosophical and aesthetic literature of the first half of the last century - in the works of A. Camus, S. de Beauvoir, J.-P. Sartre and some others. If for these authors the concept of the existential destination of man was the concept of hopelessness, irreparable living condition of man, of despair per se, then for psychologists of the second half of the century - for E. Fromm, V. Frankl, A. Maslow, B. Rogers, for the domestic researchers who were attached to the field of humanistic psychology, the word «existential» indicates the conditioned consciousness and human behavior by the practice of his existence in this world, the experience of his relations with the world - not accidental relationships, but those that define the state "human in man". 
Western authors, for example, J. Shotter ${ }^{4}$, use L. Vygotsky's name as a kind of instrument - a «key» to various transitional concepts that link psychology and literary criticism, linguistics and communication theory, and so on. In recent years, a multidisciplinary approach has become characteristic of Western humanities; domestic researchers more often use the concept of interdisciplinary method. The plurality («multi»), hence the transience, of the approach indicates that humanitarian science is increasingly concerned with borderline phenomena, which involuntarily forces to recall M. Bakhtin's words that culture - all - operates on the boundaries... To this we can add that man is formed by boundaries; it is about the internal boundaries of human relations to the world, what he can do with them, how he can know and manage them (take care of them, shift them, and so on). Particularly significant in the works of Western authors is that they not only identify and develop psychological aspects of Bakhtin's theory, but directly link Bakhtin's and Vygotsky's concepts, making the names of these researchers related in the context of the problems of psychosemiotics and the semantics of culture.

We have to admit that, in the theory of M. Bakhtin, many domestic authors look like a person who bites a small slice of a large tasty pie, carefully chews each slice with the hope of understanding what the pie is made of - instead of trying to find out the recipe right at that moment. That's how Bakhtin was «bitten» (otherwise you won't say) from different sides. That even caused a peculiar reaction - the appearance of work with the characteristic name «Leave Bakhtin alone!» ${ }^{5}$ There were no such appeals to Vygotsky, possibly

${ }^{4}$ Shotter J. Bakhtin and Vygotsky: internalization as a boundary phenomenon. New Ideas in Psychology, 11, 1993. P. 379-390.

Shotter J. Harre, Vygotsky, Bakhtin, Vico, Wittgenstein: conversational realities and academic discourses. Journal for the Theory of Social Behavior, 23, 1993. P. 459-482.

Shotter J. Vygotsky's psychology: activity in the developmental zone. New Ideas in Psychology, 7, 1989. P.185-204.

Shotter J. Vygotsky: the social negotiation of semiotic mediation. New Ideas in Psychology, 11, 1993. P. 61-75.

5 Босенко А. Власть времени, или Оставьте М. Бахтина в покое. М.М. Бахтин и перспективь гуманитарных наук: Материаль науч. конференции. Витебск, 1994. С. 83-85. 
because this author is already classified as a «classic», an academic tradition that has a respectful, distant attitude, and therefore no immediate renewal is a continuation of creative thoughts. In the meantime, for the necessary resonance of Vygotsky's ideas, it is very important to try to have a direct and close contact with his scientific thought; therefore, in connection with the fate of this researcher's inheritance, the claim «do not leave Vygotsky alone!» would be more relevant today. Anyway, both authors have identified those problems of art psychology that still remain open and form one of the leading areas of humanitarian thought, combining interest in the three phenomena that are the most difficult to understand and explain: human consciousness, sense of being, semantic content. The territory in which these phenomena and the methods of their study can be combined is the territory of «comprehensive art».

For modern psychological thought, the removal of the humanitarian knowledge, including aesthetic and artistic, the popular cultural psychology, ethical and theological concepts, and so on, has become commonplace. But it is carried out spontaneously, without showing sufficient unity of approaches, theoretical endurance. A wide zone of «dissent» also arises in relation to Vygotsky - as a change of position with regard to the subject which he was offered; in the meantime, no one is able to do it deeper than Vygotsky. Due to the complexity of Vygotsky's concept, the «circles of reading» that arise when referring to his works and to the works of contemporary authors are not comparable. Any work of Vygotsky is a text that requires special and deep interpretation, theoretical and logical readiness, a complex conceptual construction, requires «understanding inclusion» in his theory as a whole, and this theory is, ultimately, the theory of human consciousness at its various historical and semantic levels.

The semantic context of a number of works by L. Vygotsky allowed us to come to the conclusion that consciousness speaks to us not in one but in many languages ${ }^{6}$. In order to hear and understand these languages, one verbalization experience is not enough. The verbal form is only one of a number of possible lingual forms (forms of expression and communication). Vygotsky came up with this idea

\footnotetext{
${ }^{6}$ Выготский Л. Психология искусства. М.: Искусство, 1968. С. 200.
} 
when he discovered that, In addition to verbal mediation, verbalization, there may also be other forms of mediation. He did not specifically study them; he only raised the question that extra-verbal forms of communication, sign structures, extra-verbal branch of consciousness is a very promising subject of study, the subject that can open up new possibilities of psychological science.

The three distinctive Vygotsky's aporias that reveal the content of his approach are as follows. The first: Vygotsky states that we remember the meaning of what was said, and not the word; ${ }^{7}$ the «mystery» of this formulation is that it attests to two memory tools at the same time. The first known tool is the logical memory of words. But another tool that addresses the sense of "over the top" - what is it? There may not be an unambiguous answer here, but the direction of Vygotsky's thought suggests that this instrument is a special deep emotional unconscious memory, which, in fact, represents the spiritual content of human consciousness. (According to V. Frankl, the spirit and the spiritual rest on the unconscious).

Vygotsky's second aporia indicates that meaning is not about thinking, but about all consciousness ${ }^{8}$. In the interpretation of Vygotsky thinking and memory appear in the mind almost as antagonists in a certain respect, in any case - as antinomic principles. If a person is focused on the logical side of consciousness, on ways of rational work - on what is traditionally called thinking (and Vygotsky connects thinking with the processes of verbalization), then he is no longer able to deal with the entire volume of his memory. The problem with attention is - according to Vygotsky - that by focusing on one, the person is losing focus on the rest. But when a person dives into the deep meaning of his memory, he begins to coexist with it spontaneously, he loses the ability to act, that is, to plan his actions, to look at himself, to create himself from afar, and he loses the possibility of mediating his own life. A truly serious alternative to human existence is an alternative to expediency and spontaneity. This alternative is discussed by psychologists because expediency is

${ }^{7}$ Выготский Л. Лекции по психологии. Л.С. Выготский. Собр. соч. в 6-ти mомах. Т.2. Под общей ред. В. Давыдова. М.: Педагогика, 1982. С. 388.

${ }^{8}$ Выготский Л. Проблема сознания. Л.С. Выготский Собр. соч. в 6-ти moмаx. Т.1. Под ред. А. Лурия, М. Ярошевского, М.: Педагогика, 1982. С. 167. 
necessary for a person to answer the question «why» - the central question about the meaning and sense of life. But, being extremely expedient, a person lives in two dimensions - in the past and in the past, losing the ability to be «here and now», so there is a problem of returning him to the present, the problem of presence, inclusion and immediacy, spontaneity of experience. According to A. Maslow ${ }^{9}$, one of the features of a self-actualized personality is the ability to react relatively quickly and with sufficient completeness to what is directly happening, that is, to be involved in the process - and this is fair: because relevant is what is happening now, today and for the sake of today's implementations.

Vygotsky's third aporia sounds like this: every language is an allegory ${ }^{10}$. This thesis indicates that the verbal forms - with all the conceptual fixation of the word and the verbal fixation of the concept - are not identical to any semantic instances.

Vygotsky points that semantic meanings are not identical with verbal ones; sense is identical neither with sign nor meaning - it exists between them. Therefore, the word (verbal expression) as a sign structure cannot be regarded as the final and completing form of comprehension; there is always some subtext left, that is, something to which the word sends, becoming a sign of this «something», but not literally being the expression of it.

Vygotsky's approach is defined as psychosemantic, and it is supported by a triad of concepts: consciousness - unconscious memory, consciousness - imagination - attention, consciousness thinking - memory, meaning - sense - sign. The third of them reflects the antinomic nature of thinking - the memory of consciousness; the fourth closely brings to the art (aesthetic) aspects of Vygotsky's works. Vygotsky developed, as he called it, a «semantic» analysis of the word, «... which is the only adequate method of analyzing the systemic and semantic structure of

9 Маслоу А. Дальние пределы человеческой психики. Пер. $c$ англ. А. М. Татльгбаевой. Научи, ред., вступ. статья и коммент. Н. Н. Акулиной. СПб.: Евразия, 1999.

10 Выготский Л. Проблема сознания. Л.С. Выготский Собр. соч. в 6-ти mомах. Т. 1. Под ред. А. Лурия, М. Ярошевского. М.: Педагогика, 1982. С. 162. 
consciousness» ${ }^{11}$. Later, he called this analysis semantic, thereby entering the way of semiotics and semiology, the way of science of sign systems and sign functions that enter into these systems, assuming that a person can be studied as a sign system, adding - as a self-actualized system.

The traditional semiotic approach focuses more on the external form of the sign and its structural characteristics; for it, it is typical to address lingual systems - the organization of the so-called natural languages. But the semiotic approach is also applicable to artificial lingual systems, among them to the process of artistic communication. In a number of positions Vygotsky is ahead of semiotic characteristics in this area. Yes, he notes the double function of the sign as communication and generalization (mediated communication). From this he makes out the main law of «life» of the sign, the sign structure: what form of communication is, such is the generalization. The following should be added to the abovementioned. The formation of signs, which are generalizing structures, are generated by meanings («echoes» of sense), but also generate them. It is possible according to the scheme «man - man», «man thing - man», but not according to the scheme «man - object»; the sense-generating sign process is always a subject-to-subject relation. So, without using the concept of «dialogue», Vygotsky comes to the theory of dialogue with all certainty: subject-to-subject communication is specific and dialogical, and its semantic side allows to distinguish, as an independent subject of study, common for a number of humanitarian sciences, conditionally-semantic dialogue.

The creative functions of man are manifested not only in any particular forms of his activity - in the arts, in science, in technical production, and so on. The most general and integrative creative function of a person is his or her orientation in the world, ability to have dialogue with the world and self-dialogue. In addition to all other creative tasks, man has one constant - creativity of life, therefore, creativity of oneself. Nowadays, psychologists regard this position as the single and common human position of life, as the most important one, thus, not dividing the man into some of his individual

11 Выготский Л. Проблема сознания. Л.С. Выготский Собр. соч. в 6-ти moмах. Т.1. Под ред. А. Лурия, М. Ярошевского, М.: Педагогика, 1982. С. 166. 
aspects, areas of manifestation, but trying to see the factors of centering, gathering, attraction to one whole. As a matter of fact, it is precisely through the methods of centering and the internal psychological focuses of relationships with the world that people differ. Of course, one must also take into account the fact that there are social canons of centering, that is, personal self-realization, including those defined by society. One of the main problems (antinomies) of personal being is the correlation of social and individual, programmability and freedom.

Personal position - what can be called a life position - is determined by the correlation of external and internal conditions of formation of valuation approaches to the world. The tasks of such a formation are what can be called personal effort or psychological strain. Psychological tension is a direction of activity of the person, a vector of activity of consciousness, a psychological modality; one way or another, it is said that the cause and nature of the psychological tension indicate the sphere of making efforts. Effort is a force coming to somewhere, finding with some force, moving in one direction with it; it is not indifferent to its subject and always arises in relation to something. The vital position is the coordination of external and internal sides of an effort, the external subject side of the effort and its psychological conditioning, but it is always a dynamic manifestation of personal consciousness, that is, tension. In M. Bakhtin's works the concept of «emotional-value tension» is found; another concept is synonymous to it - "emotional-volitional effort" $"$. With these words Bakhtin defines the meaning of the vital position within, which can also be called the intentional form of human existence in culture.

External object and factual plan of personal expression and «deep semantics» of human consciousness, with all their interdependence, find different ways of sign design as ways of «portraiture» of man. When we talk about portraiture, we mean that it reproduces,

12 Бахтин М. Автор и герой в эстетической деятельности. М.М. Бахтин. Эстетика словесного творчества. 2-ое изд. Сост. С. Бочаров. Прим. С. Бочарова и С. Аверинцева. М.: Искусство, 1986. С. 9-191.

Бахтин М. К философии поступка. М.М. Бахтин. Работы 1920-х годов. К.: Наукова думка, 1994. С. 9-68. 
remembers one or another human world, real or perfect; it is the reproduction of those bonds that exist in the individual with the surrounding continuum. For example, the so-called ceremonial baroque portrait was oriented to reproduce the image of the subject (as a certain «character»), not in a casual or everyday situation, but with the presentation of the full weight of his social status. The baroque portrait is therefore called ceremonial because the person depicted on it and transformed into a character of a social play, appears in the best, the most perfect of its appearances. The «hero» of the portrait must look good, be in a wig, an indispensable attribute of the social appearance of a baroque character, in a ceremonial uniform (uniform): all his social awards, insignia and so on must be depicted. This tendency is kept by the portrait for a pretty long time - until the XIX century, in the Baroque era every other image of a person was not considered as a portrait. Baroque portrait is a good example of the boundary expressiveness of the external type of portraiture. In this case, the specific personality traits of a person - a characteristic facial expression, the most peculiar look - were no longer relevant, although the similarity with the prototype remained; the character had to develop himself, but he had to look at the world literally with the view that was adopted at a given time in this society, to have the facial expression corresponding to the social expectations. If he did not have it, then the painter simply «added» it - and that is how his skill was assessed. With all the need for a portrait resemblance, the portraitist was the least copyist («photographer»); he reflected not so much the appearance of the subject as a given, psychologically programmed, social model.

When we talk about internal portraiture, it means that the iconic model of a person can completely free himself from the external appearance, from the realities of contours, in fact - from any contours; it reproduces what the Greeks called entelechy - the inner essence or the eidos - the perfect prototype of the real object, which most reveals its essence. The internal psychological model is in its purest form abstracted from the external conditions of being of the subject. Hence the boundary conditionality of internal portraiture, its right to freedom and, speaking of fine arts, the increasing musicality («musicalization») of visual technique, the increasing «intonation» and a departure from external cruelty. A good example is a canvas 
that has become a manifestation of expressionism - E. Munch's «The Scream», which depicts a conditioned human face with floating contours that have nothing to do with real outlines. The subject of the image is a state of despair, a borderline state of consciousness, a psychological crisis, protest and other similar psychological phenomena. The name itself suggests that this canvas should be not seen as much as heard. The veiling of the lines, the blurry image, the approximation of the image, the amorphousness of the subject part forces the viewer to complete the picture in the imagination, to perceive its sign structure as allegorical, which refers to what is not shown in the picture because it cannot be shown, but can only be heard - the scream. Undoubtedly, the tendency of internal psychological portraiture with its interest in the borderline manifestations of a person's psychological arrangement is most evident in the art that we consider to be the latest - from the late romantic period to the XXI century; but its prerequisites are in late medieval paintings and in the paintings of F. Goya; there have always been breakthroughs in the arts to a field that would later be called expressionist and surreal.

It is the interest in internal psychological portraiture that expresses the right of art to change, deform, transform reality, to transform the human image, appearance, to the new conventionality of the artistic sign system, and so on. In this regard, we denote the two poles of psychological modeling of man, known to the arts, they can be called genre and semantic. One pole is utopia, the construction of an ideal world and a man who is nearing perfection in this ideal world. The so-called idyllic literature, the idyllic genres of painting, are connected with this utopian direction, and one can speak of an idyllic tendency in musical art. Utopia generates an idyll closely linked to it, because idyll is only possible in Utopia - in a place that is not present, so where a man cannot stay. The place where it is impossible for a man to stay, but to which he is striving so hard, becomes a place of idyllic communication of people. In the psychological literature, idyll is regarded as one of a kind of psychological situation; it is related to the wish for the ideal and the belief in the achievement of the ideal - at least beyond real existence.

Another pole is the tragedy worldview - the antipode of utopia. In a utopian-idyllic world, everything is safe and free from real time 
dependence; in the world that is tragedy for man, everything is irreparably dramatic, lasting conflict and irreversible in the sense of physical short-term life and the futility of efforts to prevent his passing away from this world. In the world of tragedy, everything obeys the law of the year, which reigns over a man who cannot be saved, and therefore the state to which a person comes while in tragedy is a state of loss of hope and hopelessness. By its artistic task, tragedy (when it is really a tragedy aesthetic phenomenon, so it implements all the rules of tragedy) must confront man with this with the hopelessness of human presence in the world and human attempts to change it for the benefit of man. Why does tragedy set itself such a challenge? Because awareness of this fact annoys people the most. Nothing with such force leads a man to a state of activity, or vice versa - to a total rejection of all activity.

The tragedy claims to find two ways of considering it in a psychological aspect. The first, positive one - is heroism; the other, existentialist, - is suicide. So the tragedy situation exacerbates all the contradictions of human being in the real world. Therefore, tragedy, whatever material it is based on, whatever it appeals to, must always rely on a specific life experience, maintain the rule of vitality. What happens in a tragedy must be easily designed by the subject for personal experience: it must be something that can happen to each of us at any time. Tragedy in some respects always reproduces the idea of E. Hemingway's famous novel, «For whom the bell tolls» (considering that the author «hears» the bell as the sound of funeral, the sign of disaster, as an alarm - a danger signal): wherever and whenever the bell rings, you should remember that it is tolling for you... There is no danger signal in the world that would be irrelevant to each of us, and you need to live with that in mind. This is a tragedy and a lesson that should be learned from the tragedy.

So, two polar models of man - the utopian man and the tragedy man: a man who is in a world without contradictions and conflicts and a man completely enslaved, torn by irresistible antinomies of being. There are several transitional models between these polar models, but in our opinion the most semantically responsible of them is melodrama - as a genre and semantic branch of art, as a kind of aesthetic phenomenon, finally, as a type of interpersonal (subject-tosubject) relations and a form of self-expression, self-esteem. The 
importance of melodrama is due to the fact that, on the one hand, staying in a state of utopian bliss for a long time is dangerous: there is a separation from reality, which in turn can lead to the development of one form of autism. But being in a state of tragedy for a long time can be terrible. The tragedy experience has a high intensity, but it is brief: tragedy emotion cannot last long; it immediately seeks for some rest - unlike lyrical emotion. The melodrama combines dramatic and lyrical experience, points to those situations, psychological relationships, when there is some opposition between the external circumstances and the internal settings of the subject, but this opposition can be resolved in each of the parties. Subject is given the right and opportunity to change his setting, to understand himself, to empathize to himself and to discover special internal forces; and external circumstances also allow their change. The difference between drama and tragedy is that drama offers a happy ending. A happy ending in a tragedy - even assuming its possibility destroys the tragedy. The drama does not require the death of the best character - unlike tragedy. Rather, it builds the instincts and practices of self-preservation and survival of the individual, including by enhancing the experience of emotional reaction, and this is why it becomes a melodrama.

A compulsory attribute of the melodrama is a fairly convincing long-term disclosure of character's emotional state, his experience. This is how the lyric component is put into the melodrama. Longlasting individual emotion, motivation of the plot by personal experience, the opportunity to dive into this experience and discover its beauty is the necessary moments of melodrama. That is why the equivalent of melodrama in music is operality; as a melodrama, opera justifies all expectations of human consciousness. It can be said that opera, as a synthetic genre, though predominantly a musical one, is a genre branch, most satisfying the current constant psychological inquiries of a person, which explains its success in the history of culture. Strictly speaking, we do not know any era associated with the development of musical art (that is, music as an autonomous area of professional activity), when opera was not among the leading genres. But also the «pre-opera epochs» or, in the words of R. Roland, «opera to opera», which include mysterious, liturgical forms, referred to music as a way of achieving emotional involvement (empathy as a 
necessary side of communication), finding emotional self-sufficiency the moment when it is a prerequisite for relations with external reality.

Melodrama, as one of the general and basic forms of artistic poetics, establishes psychological capabilities of a man, first of all, his experience of experiencing, with actions, with the ability to come, to be included in the event life series. In this way, melodrama combines the ideal and real human worlds, not staying in either of them forever, but pointing to the possibility of transition from one to another, which is its dialogical nature. Melodrama as a certain position - both artistic and psychological - has a high level of transience, in particular, it is a connecting branch between elitist and mass art. For the latter, for the mass genres, utopian and tragedy directions are not typical. But mass, applied, everyday, semiprofessional, amateur genres have always been and will be necessary precisely in that they form the basis for melodrama and melodramatic entry into reality, melodramatic perception of the world; they create the habit of emotional reaction, include individual emotional experience to the conventional, produce typified forms of experience, and so on. We can say more sharply: mass genres in all kinds of art are turned to the banal experience, without which there would be no original. The reverse interaction is also possible, by which we assume that the banal is the original, which has become ubiquitous.

Considering the different positions regarding the psychological models of man, distinguishing from them those that significantly influence the genre directions in art, we note two more factors. The relation of man to his own capabilities, his activity of comprehension - the definition of reality and himself in it, has always been projected into two spheres - the sacred and the profane. The sacred - the profane is the through antinomy of human culture, revealing an important positive opposition within cultural semantics. At the same time, the profane absolutizes the external materialbodily, carnal, earthy, «bottom» manifestations and interests of man; the sacral, on the contrary, is based on the desire to release the spirit, on the inner secret «anagogical» meaning of human consciousness, absolutizing the invisible higher, «upper» being. In the process of cultural evolution, both of these common forms of human experience are equally necessary... 


\subsection{Cognitive attitudes of modern musicology as methodical factors of psychology of arts}

The immanent integrity of contemporary musicological research is determined by the combination of three methodological approaches: formal and logical discursive modeling; empirical definition nominations; phenomenological reflection (discussing music in the «language» of the consciousness intentions). But the epistemological musicological style breaks out when the subject of cognition becomes personality, when «the entire person who remembers, loves, understands ...» is needed, and a dialogue between the consciousnesses in the projection of the problem of human lifecreation is carried out. So, when the dominant factor of scientific logic becomes the «inner form» of the musicological word.

It should be recalled that O. Potebnya called the inner form of the word the relation of the content of thought to consciousness, through which a person becomes subject to his own thought; he believed that in our soul there is a special carrier of senses, which has various features and provides a holistic image of the object by which unconscious thoughts express themselves. The features of this image form an internal modal form of the word - modal because it indicates the way the word is included in the discourse, its relation to another word, its ability to become a «word about word», and, thanks to new conceptual connotations, a word about sense, that is, to gain symbolic completeness ${ }^{13}$.

D. Leontiev's research positions make it possible to state that in the analysis and the means of representing the sense, according to E. Husserl and according to the tradition of the phenomenological approach, the noetic (noesis) or description of the experiencing act, and the noematic, or a description of «what is experienced» are distinguished $^{14}$. E. Husserl understood noesis as comprehending intentional orientation of consciousness to an object, and noema - as

13 Див.про иче: Камчатнов А. М. А. А. Потебня и А. Ф. Лосев о внутренней форме слова. Русский филологический вестник. 1998. № 1-2. С. 16. URL: https://sites.google.com/site/kamchatnoff/ Дата доступа: 15.10.2015.

14 Леонтьев Д. Психология смысла: природа, строение и динамика смысловой реальности. 3-е изд., доп. М.: Смысл, 2007. 511 с. 
an experienced object itself as a sense bearer. The first is connected with comprehension as awareness of reasons and expediency, forms of sense presentation; the second - with logisation as a choice of explication principles of sense, its definition. The internal form of the word is a mediator between the process of comprehension and the possibility of embodiment the noetic experience in a symbolic form; «external», conceptual form captures the received intentional message in the chosen communicative and cognitive context.

Obviously, these two characteristics - intentionality and contextuality - should be considered as two indispensable attributes of musicological knowledge, invariant to specific definitions and concepts. But there is a substantial need to add to these two dimensions of musicological thinking one more, which points to the fundamental ethical importance of musicological knowledge and assessment, organically entering the nature of style in its general aesthetic and cultural sense. It is responsibility that is a key word in M. Bakhtin's philosophy of life as a «philosophy of action»; it is derived from «correspondence» («responsibility») and already in this capacity, it shows dialogicity as the starting position of the personality in the world. M. Bakhtin's words: "The correct, not selfproclaimed content of all the old questions about the relationship between art and life... the true pathos of them is only that both art and life seek to facilitate their task, to remove their responsibility, because it is easier to create without answering for life, and easier to live in spite of art. Art and life is not one thing, but they must become one in me, in the unity of my responsibility (italics is ours $-A$. S) ${ }^{\prime \prime \prime}$.

Let us continue quoting M. Bakhtin's statements, because of them it is possible to get the main essential purpose of speech and thinking style: «The very definition of style in general and individual style in particular requires a deeper study of both the nature of expression and the variety of speech genres...» ${ }^{16}$; style is combined with a person by

15 Бахтин М. Искусство и ответственность. М.М. Бахтин. Эстетика словесного творчества. 2-е изд. Сост. С. Бочаров; прим. С. Бочарова и С. Аверинцева. М.: Искусство, 1986. С. 8.

16 Бахтин М. Проблема речевых жанров. М.М. Бахтин. Эстетика словесного творчества. 2-е изд. Сост. С. Бочаров; прим. С. Бочарова и С. Аверинцева. М.: Искусство, 1986. С. 254. 
«persuasiveness» because «it is determined by the essential and creative relation of the word to its subject, to the speaker himself and to the far word; it seeks to organically attach the material to the language and the language to the material..."17

For Bakhtin, it is undoubted that the artistic lingual style expresses the creative activity of the author's consciousness and, as a branch of techniques, that is, from the textual stylistic side, is subordinated to the following expression: "What makes the language concrete and not completely translatable worldview is the style of the language as a whole (in communication with an alienlanguage the «worldview side is illuminated and objectified ${ }^{18}$; “... Style either straightly and directly penetrates the subject, as in poetry, or refracts its intentions as in fiction (after all, the novelist does not teach an alien language but builds its artistic image)"19; «In fiction ... individual style is directly part of the very task of expression, is one of its leading goals ...» ${ }^{20}$

Thus, defining musicological cognitive style as a semantic or noetic phenomenon, one can find in it the expression of ethical unity of thinking and language - a figurative, rational and logical, intuitive and formalized plans of consciousness in the process of answering compatible questions of art and life, in the process of their responsible implementation one to one. Therefore, the category of style of thinking can have a special scientific function, become a key in the study of the history, ethical and aesthetic essence of musicology, it also helps to prove that for the musicologist, the semantic world is the main addressee and intentional object, but the nature of this subject makes it come closer to it from afar, by

${ }^{17}$ Бахтин М. Слово в романе. М.М. Бахтин. Вопросы литературы и эстетики. Исследования разных лет. М.: Художественная литература, 1775. С. 189.

18 Бахтин М. Из предыстории романного слова. М.M. Бахтин. Boпросы литературы и эстетики. Исследования разных лет. М.: Художественная литература, 1975. С. 427.

19 Бахтин М. Слово в романе. М.М. Бахтин. Bonросы литературы $и$ эстетики. Исследования разных лет. М. : Художественная литература, 1975. C. $189-190$.

20 Бахтин М. Проблема речевых жанров. М.М. Бахтин. Эстетика словесного творчества. 2-ое изд. Сост. С. Бочаров; прим. С. Бочарова и С. Аверинцева. М.: Искусство, 1986. С. 254. 
complexly mediated contextual way, sometimes moving through almost the entire history of music, maintaining a personal point of view, as it was suggested by N. Savitskaya in her research ${ }^{21}$.

The personal point of view, or what can be called a life position, is determined by the correlation of the external and internal conditions of the formation of valuation approaches to the world. The tasks of such a formation cause what can be called personal effort or psychological strain. Psychological tension is the concentration and orientation of the energy of consciousness that form a certain psychological modality. The effort leads to its object; actually, it is intended in the dynamic action of the personal consciousness, becomes noticed by it due to emotional-value coloring. No wonder, M. Bakhtin generously uses the concepts of «emotional-value tension» and «emotional-volitional effort». In these words Bakhtin defines the content within such a vital position that becomes an ethical act - the declaration of «not-alibi-in-being».

It is from such personal value-volitional tension that three conceptual and methodical directions of N. Savitskaya's scientific theory emerge, conditioned both by the multidimensional nature of discursive orientations and by the extraordinary ability of the author not to deviate from the chosen way of comprehension and conceptualization. They act at the same time, although they exhibit some hierarchy in the structural logic of musicological discourse. They can be defined and nominally presented as follows: personalitypsychological; chronotopically age-old as a gateway to life-giving sense or personal temporal and semantic; acmeic and style. The symbolological orientation of the first is consistent with the factual background of the second and ends in the axiological plane of the third, allowing the formation and verbal and discursive presentation of a completely new, discovered by the researcher, author's musicological subject: the chronicle of composer's life creation.

The first direction is most and closely related to the problem of comprehension, which is the main prerequisite for «second-class symbolology» in modern humanitarian knowledge. We should recall A. Maslow's view that the symbolic language of theology emerged as

21 Савицька Н. Вікові аспекти композиторської життєтворчості. Дис. ...докт. мистецтвознавства; спец.: 17.00.03 - музичне мистецтво. Київ, 2010. 385 с. 
a system of metaphors for describing and broadcasting boundary experiences, therefore, the language of the great mystics is nothing more than an attempt to describe the knowledge of experience, that is, holistic states of consciousness that have a completely "earthly» real nature. According to N. Savitskaya, who explains the author's own way of defining the subject of the study, "it is impossible to understand the motivation of profound changes of consciousness and the way of artistic thinking, the psychological and mood spectrum that prevails within the various stages of the creative cycle, while remaining in the subject field of musicology. Leading scientists have returned their faces to a man as a supreme integrating substance, and in the realm of intellectual and creative activity - to the personality of the artist in an unprecedented range of emotional, reflexive and creative manifestations, in particular, in being involved to God, the Cosmos, Mankind, in the awareness of the finitude of being» ${ }^{22}$. Still, the researcher notes, «The concept of "creative personality", which becomes identical at the intersection of existential and professional evolutions, goes only partially under formalization because it coordinates a wide range of marginal aspects. These include the dynamics of personal and age changes, socio-cultural and national mental situation of artistic self-realization and others" 23 .

When the sensory work of consciousness joins the subject area of research, the meaning of experience as the main source of sense («experience is the trace of sense in life», as M. Bakhtin writes), the question of the nature emotions (psychology of emotions), the musicological word acquires aesthetic generality, which not only does not interfere with the conceptual accuracy and prudence, but on the contrary, promotes the definition of new subject-cognitive boundaries of the term. These features of verbal musicological creativity are confirmed by the following method of reasoning and verification of thought, suggested by N. Savitskaya: «The monologue of the author organically combines philosophical abstraction and intimacy, and still, the world of the soul triumphs over the objective reality. High culture of reflection increases the importance of individual existential

\footnotetext{
22 Там же. С. 56

${ }^{23}$ Там же. С. 55.
} 
space; the initial emotional and mood setting, creative activity - its optimal implementation becomes a priority.

The powerful force of psychological experiences gradually begins to be realized as a priceless heritage of the era, a treasure trove of inspiration that gives continuous impulses to creativity. Individual, sincere, sensual comprehension of the world is enriched by such emotional states as expectations, premonitions, longing for the ideal, flare of imagination, insight, creative exaltation, catharsis. Music reflects these ephemeral states, becoming a «cry of the soul».

N. Savitskaya manages to explain why «the phenomenon of personality is at the center of psychic, age-old, philosophical, anthropological, gerontological, cultural and art studies» ${ }^{24}$ in two vectors - both on the part of the composer and on the part of particular musicological interests. Firstly, "sometimes the identity of the artist is more interesting than his heritage that lives an independent life - at other times. The subjective and personal impulse is always at the epicenter of creativity, developing synchronously with professional activity"; secondly, «modern musicological thought, aimed at comprehending the psychological structure of the composer's personality, continuously deepens and at times radically rethinks the most important categories of its own scientific arsenal, which is intensely enriched with concepts borrowed from other fields of knowledge ${ }^{25}$.

Choosing as a key concept «the structure of the composer's personality in dynamics», the musicologist focuses on the «image of the author», "which reigns at the epicenter of all the fields of artistic activity».

The second conceptual and methodical direction, opened by N. Savitskaya, is combined with the phenomenon of creative forces of consciousness, with the creativity of personal consciousness, including the phenomenon of psychological time; it leads to the recognition of consciousness as the most important form of being (L. Vygotsky), the development of psychosemantic aspects of the theory of chronos, and, finally, to the creation of a chronotopic theory of musical creativity - as creativity, conditioned by time, including

\footnotetext{
${ }^{24}$ Там же. С. 74.

25 Там же. С. 4.
} 
age, aimed at the equation of time and ideas about time with constant semantic meanings of culture. In this direction, the importance of the theory of self-actualization of A. Maslow, the theory of «personal senses» of A. Leontiev, and the «acting psychology» of V. Roments, and the age typology of musical styles in their personality and author's embodiment and meaning grows.

It is thought that in this direction the leading question is the «language of consciousness» (the ways and forms of awareness rationalization), including the meaning of verbalization process words as a sign form, in general about semiotic functions and the semantic structure of consciousness, about empathy and catharsis. Therefore, the affinity of this area of research with the first is also revealed. The main thing here is the recognition of the active role of individual personal consciousness in time and in relation to different forms and dimensions, means of conceptualizing time. N. Savitskaya writes: "Time as an attribute and concept of the real world is a measure and formative factor of human being, in particular, a measure of the past; objective chronological time is one-vector, linear, translational, subjective psychological time is many-vector, reverse. This set of characteristics is very indirectly correlated with the external event series and can only be understood in the projection on the inner world of the artist. Time passes through consciousness in the form of memory of the past (memoria), experiences of the present (intellegencia), foresight of the future (providencia); it, as an elusive sign, marks the most significant events of creative biography, waves of emotional exaltation, dramatic situations of spiritual crises, the stage of transition from being to no-being",26.

From the definition of the temporal conditionality of human consciousness («psychological age») the category of creative age «scientific universal that is derived from the chronos, which serves to specify the temporal coordinates of individual development $\gg{ }^{27}$, is separated; rather paradoxical, significantly twofold, because it indicates at the same time defeat and victory of a man in a duel with time. The duration of the creative age, which makes it possible to periodize it, in particular, the identification of a fruitful «blessed» late

\footnotetext{
${ }^{26}$ Там же. - С. 109-110.

27 Там же-C. 111.
} 
period and style, according to N. Savitskaya, is not always enough. But there are special cases where a short creative journey has such an amazing intensity that the author manages to complete all his artistic (or any other) fateful tasks, to see not only his own achievements from the top of style self-realization, but also the next stages of personal development of style consciousness, so to say, to reach with consciousness to the late-styled coordinates of creative age, without having time and forces for natural physical aging in a life reserve...

The concept of creative age implies the definition of acmeic chronotope of personal style, so the musicologist leads to the development of acmeological criteria for the assessment of artistic personality. This is related to the third area of research, which is especially relevant to the search for modern age psychology, not only the psychology of consciousness, but also the psychology of the unconscious (in the words of L. Vygotsky, «the unconscious is potentially conscious»). It is the degree and duration of the productive interchange between the conscious and the unconscious that determines the completeness and personal heuristic style of thinking, leading to a special «age of acme» (N. Savitskaya), which emerges as a timely metaphysical dimension of human creativity, allowing to give a new noetic sound to the "«mental silhouettes» of real acting people" and to form "a new scientific perspective - the creation of a kind of microhistory of a macro-human ${ }^{28}$, to condition its confident modulation to the acmeological» tonality of interpretation «(term of V. Demiankov). After all, "acmeology studies the age at which people in the creative professions reach the peak of their abilities; it explores the preconditions and motivations for the interval length of the prosperity period. The vast majority of acmeologists stand in solidarity that a mature, formed personality is the one that has a clear idea of its own sense in life. Thus, the age of acme gives impetus to the formation of a special psychological field of integral knowledge about the creative personality in the peak phase of professional activity» ${ }^{29}$.

The third direction of the author's musicological discourse of N. Savitskaya forms the general acmeic intoneme of the study,

\footnotetext{
${ }^{28}$ Там же. С. 377.

${ }^{29}$ Там же. С. 71-72.
} 
revealing its orientation to the «top-semantic» characteristics of composer's life-creation. Like some other categories, the concept of acme and acmeological approach is of symbolic importance because it meets the need for symbolization - metaphorical exteriorization the psychological content of human consciousness in its totality. By integrating all its subject intensions and contextual interferences in the top phase of the study, the acmeological interpretation opens up special methodological projections of the psychology of arts in its new current disciplinary significance.

The acmeological approach points to three possible and predictable by research structure of N. Savitskaya's components sections of psychology of arts: psychology of consciousness, psychology of creative process, which includes psychology of artistic creativity, psychology of musical thinking. Psychological theory of consciousness most requires the definition of criteria, methods of assessment, lingual description of personal and semantic phenomena, the formation of basic concepts, terms, and the choice of concepts the creation of appropriate to the subject discursive field.

The study of the creative process, including its artistic forms, resonates with those ideas of L. Vygotsky, which are concentrated in the «Psychology of Arts», as well as with his theory of signification, which is included in the doctrine of higher psychic functions of a man. In other words - it is directed to the sign activity of man; in turn, it depends on the creative and semantic tasks and needs of a man, and most of all, on those who «crown» and complete cognitive human efforts, represent the highest historical experience of humanity as a single evolutionary organism.

The third component of the psychology of arts is already specific, but of broad theoretical action: it is the specificity of musical thinking that allows you to penetrate most deeply into the processes of awareness and to clarify the meaning of the «internal form» of the sign construct, to identify the dependence of thinking on types of communication. On the other hand, the psychological approach allows us to look differently at the process of musical communication and to reveal the peculiarities of interpretative approaches in music and to music, to explain the peculiarities of musical language, which is created through self-dialogue, and finally, to reveal a particularly close connection between the musical and the unconscious, which 
allows the human consciousness to attain its own aesthetic acme, transposing the content of the unconscious into the top thinking forms.

Therefore, we are convinced that sense and language are obligatory aspects of human activity, which, depending on its forms, are based on different levels of culture (in different spheres of it), but come to life only with personal touches. The place of their descent mutual recognition, harmony, harmonious resonance - is the ethos of culture (in the primary quality and symbolic purpose of the word). From such a cognitive and methodical standpoint, the nature of musicology is initiated by: the need to find differences between the immanent-musical, implicit sense of music and the non-musical way of comprehending musical content, the explicit theoretical tasks of music science. Musicology exists in a rather difficult situation of selfdialogue; because it must overcome the non-agreement between the sense and its linguistic realities (discursive meanings) embedded in the music itself, identify the duration and volume of the «semantic history» of the symbol, thus meaningful over-accentuation, motives of value choice, which is the leading side of human cultural consciousness.

In other words, musicology is inevitably confronted with the need to explain why music is either "greater than its fate» (the possibility of individual expression, the meaning of a separate compositional embodiment) or «less than its musicality» (the idea of music as a fundamental openness of the process of semantic formation of a person in being). The latter forces to draw attention to the selfdialogue of music as to its true knowledge of itself, which has the character of answering not to temporal, but to constant, time and space perspective, existential questions. Musicological discourse arises from the effort of expression, responding to musical «questions»; one can even say that the semantic overflow of a musical text leads to its musicological interpretation and translation and reveals a fundamental difference between musical and musicological languages.

The main focus of the first, including historical evolutionary from the whole (semantic) to its detailing cognitive components, which, in fact, carry the function of specific musical discursiveness, based on the structural and functional multiplicity of musical text. 
The architectonical feature of musical language is the reproduction of sense as the leading aesthetic idea of human being. To make the play distinct, that is, ready for perception, «understandable» - an instrumental function of the musical form as a way of designing the «sound matter of being» in the conditions of composition is checked every time once again.

Following M. Bakhtin's position, we may suppose that the nonmusical way of the aesthetic extends from the completeness - the separation of its significant fragments - to the non-completeness and the impossibility (anagogicity) of the semantic whole. Its musical way is from the instant embodiment, hence the completeness of the implementation of the whole in each of the fragments, but as open, incomplete in their artistic values. Extra-musical completes the aesthetic, dissolving, losing it in «verbosity» and pragmatism of everyday life. The musical transforms the aggregate moments of life experience into an aesthetic idea, presenting the experience of empathizing with the integrity of spiritual search, crystallizing the aesthetic in its «methodical purity»... Everything that exists outside is alien to music, so, this way or another appropriated for the purpose of revealing oneself (musicality) through the rest. Undoubtedly, its only the fact of acting through sound that does not allow the direct interpretation. However, music has its own interpreting mechanism, which can be alienated in theoretical categories, also in more or less specific concepts-images.

The idea of music is formulated as a system of logical space and time - chronotopic - rules that combine procedural and structured principles in all plans of compositional formation. This is the logic of music's own responsibility, its ethical assessment, if we recall Bakhtin's thoughts. The nature of musical assessment - in comparison with other cultural norms - changes markedly under the influence of the always positive attitude of aesthetic comprehension (comprehension as an aesthetic phenomenon). Even all the rejections (elimination - alienation) in the music are deeply positive; only the lack of implementation of its main cathartic idea can be negative. The latter in music (unlike other spheres of culture) clearly indicates its own holistic character with an emphasis on the ethical side. Music transforms the catharsis of a vague psychological phenomenon into the responsibility of ethical choice, and makes it through its ability to 
appropriate the experience of moral cognition and give it unconditional character, absolute - not externally authoritative, but internally convincing, aesthetically experienced.

But this is why there appears a fundamental theoretical opposition of musicology to itself, which is also explained by the contradictory nature of music, in which integrity of sounding that cannot be separated without losing the unity of its sense, and the compositional and textual fragmentariness of the experience of musical creativity conditioned by its internal differences (which contradicts the unity of musical consciousness) is always near. The difficulty that always remains is the definition of a justifiable interpretative connection between music as a specific form of knowledge and knowledge about music, a specific form of musicological experience.

Relying on the concepts of integrity, fragmentariness and conditionality contributes to the objectification of the semantic, compositional and dramatic functions of music, each of which expresses the interaction of alien - its own as a non-musical musical and reveals, through this antinomy, the natural musicality of the main noetic texts. There is nothing else for musicology than to stay between the named partners in the dialogue as a «third voice», «Over-addressee» (M. Bakhtin's concept), striving for an ideal world... This position for musicology is revealed as intended «disposition» by the musical nature (if we approach the terminology of M. Bakhtin), which obliges to find metatheoretical disciplinary companions, in particular in the philosophical, cultural and psychological fields of knowledge.

The question of why musicology with its broad claims to theoretical modeling of musical sense (let us recall G. Hesse's statement: if there is sense in music, then it does not need us...), which arose in connection with the musicological "crisis of identity", provokes a reformulation: music does not need a musicologist, but it is necessary for him as a material and a factor of discussion «saying» of the musicality of the main intentions of Being-In-Man and Man-In-Being, symbolic and symbolizing, and in the process of interpretation symbolically submitted senses the music itself is interested, defending not only its immanence of sense, but also its ability to be perceived. 
In the great symbolics of culture, there is always musicality, because it must be heard and experienced, not only conceptually but also figuratively, not only as artistic allegory, but also as a voice unity of reality (both conditional - and unconditional, both unindentifying - and complicity-total, as a whole-to-whole action perception).

Musicality as a co-being of music can be ruled by the language of «other-scientific symbolology» (S. Averintsev), which does not belong (as well as the senses of music) definitively to any one humanitarian discourse, but is important for everyone and indirectly rules everyone; it is mostly objectified in aesthetic terms, pointing out, at the same time, the privileges of aesthetic criteria when discussing music and the ambiguity, multidimensionality (breadth, depth) of the phenomenon of aesthetic in culture and its symbolic origin.

The aesthetic for musicological cognition is wholly its (and most perfect), but it is alienated by the experience of life and culture, from where it comes in a weird form. In removing this weirdness and returning to its aesthetic «methodical purity» (M. Bakhtin), one can find a common cathartic function of musicological dialogue with music, the performance of which, however, requires long explanations, both in connection with the concept of methodical purity and regarding the specifics of the musical method. The «long way to catharsis» in music forces musicologists to build up patience and endurance as companions of scientific and theoretical mediation...

The return («the festival of sense revival», according to M. Bakhtin) of the essence of the aesthetic in music is determined by the instantness of its understanding and acceptance, as confirmation of its semantic over-givenness. Musical and aesthetic and nonmusical and aesthetic are distinguished as ways and levels of comprehension, that is, as the correlation of meanings and sense, interrupted and continuous in meaning realization, as the basic noetic boundaries of the comprehension of dialogue, which, however, are locked on the common activator, on the human personality.

The fact of creating a musical sense, that is, a sense said by musical sounding, becomes the task of bringing exclusively the immanent quality of the musical image to the extra-musical 
assessments tested by the reality of life and culture. Extra-musical factors in music become mediators of semantic meanings, reinforcing the conventionality of the musical - not only as alien to it, but also as its fragments, its explicative parts. According to Bakhtin, this is a special sign of the form penetration into the content, the form realization in the sense formation: “... in the process of creativity there are alien objects: musical instruments, a cutter, etc. $<\ldots>$ Having passed through these alien intermediary objects, the activity of the author and creator specializes, and becomes one-sided and inseparable from the sense it has formed" ${ }^{\prime 30}$.

Not finished, this Bakhtin's observation seems to be very productive in many aspects of musical intonation as an experience of «alien appropriation,» such as timbre, articulation, rhythmization, and so on, to consider the various possibilities of musical sense indication. It is the factors of the conditionality of music that can become the subject of musicological attention, after the musicality the idea of music as an object of musicology. Symbols reproduced by music and in music, combining its object content, can be determined on two sides: from the noesis of culture and from the external realities of musical language. The way from musicology to the range of humanitarian sciences, including psychological, seems more productive in this respect than the other way around.

\subsection{Musicological perspectives of «psychology of arts» by L. S. Vygotsky}

The main question that arises today at the meeting of musicological thought with the «Psychology of Arts» by L. Vygotsky, as well as attempts to explain the concept of this work, is the following: what is the reason why the contemporary musicologist is interested in the named work and what the musicological approach to the psychology of arts can serve to?

Leaving aside the fact that this relatively early work of Vygotsky undoubtedly reveals the methodological basis of the psychology of

${ }^{30}$ Бахтин М. Автор и герой в эстетической деятельности. М.М. Бахтин. Эстетика словесного творчества. М.: Искусство, 1986. С. 71. 
arts as an independent, albeit transitional, disciplinary humanitarian direction, and still remains unrealized in this aspect. Our present task is to show the importance of Vygotsky's thoughts for solving the key problem of musicology, which is only growing with time, namely, the problem of music as an artistic form, which becomes not only a guide, but also a generating context of the main (starting) cultural senses.

Usually, the interest of art critics and aesthetics in the «Psychology of Arts» of Vygotsky (and its popularity) is determined by the definition of catharsis in the pages of this book in connection with the nature of artistic emotion. And the gaze of the musicologist also mainly turns to the ninth section of «Psychology of Arts», which directly explains the concept of catharsis. The fact that this view omits more than two hundred pages of previous text is justified by the fact that this text is dedicated to critiques of various aesthetic theories and that is why it may seem preliminary. Indeed, the sections of the work that develop the question of catharsis are completely independent and give a comprehensive coverage of the emotional basis of catharsis in art (in literature, above all). In addition, the content of these sections is quite revolutionary, since Vygotsky more clearly than other authors, arguing the course of his analysis with specific literary works, proves that catharsis is not only a tragedy, but is obligatory for all artistic genres, it characterizes the aesthetic nature of art in general.

L. Vygotsky pays attention to three qualitative features of artistic emotion. The first is related to the fact that artistic emotions represent «emotional thinking», that is, «reasonable», «central», manifested in the heightened work of consciousness, but not in external action. Let us recall that, according to $\mathrm{Z}$. Freud, if in life, when a person feels fear, it is useful that he escapes, then in art it is useful that he does not escape, but feels fear. The effect of art in comparison with the everyday situation is the exact opposite because in art a person finds himself in a special position: he is the subject of artistic communication.

Another feature of artistic experience is its specific intensity; Vygotsky examines it in connection with the question of economy and expenditure of feelings. He asks: do artistic emotions help us conserve our strengths or, conversely, waste them? Vygotsky also 
reproduces the famous question from Shakespeare's Hamlet, given by Hamlet himself in the Mousetrap scene: "What's Hecuba to him, or he to Hecuba, that he should weep for her?...» Being rhetorical in Hamlet's mouth, this question does not remain rhetorical for Vygotsky. He gives the following answer: artistic emotion is the «lose of forces» that turns out to be their considerable savings. To understand the meaning of these words, we should turn to the third feature of artistic emotion, namely: this emotion becomes the highest productive economy of mental strength and preparation of our consciousness for the future, in some respect - the prediction of this future, with the focus of all emotional work of consciousness, because it leads to increased imagination, fantasy. And at this very moment, in connection with the work of fantasy, there is a need for «something huge», although indefinable. This third sign of artistic emotion draws attention to the fact that imagination always activates the reserves of the unconscious or the unconscious as a reserve of special forces, abilities of consciousness; but it does not explain how these forces work and what they represent.

This should be facilitated by the fourth decisive feature of artistic emotion, which is associated with the most direct definition of catharsis: it is an «affective contradiction», a «transformation of feelings», which is possible insofar as the material of an art work and its form evoke opposite rows of emotions. However, this is where the greatest ambiguity arises: any experience (any sensory process) for us, in the internal flow, is holistic and unidirectional. The opposite, of which Vygotsky writes, is caused by the difference in the origins of emotions, from the «turbidity of life» or from the «light breathing» of art, is conditional and in the art work is overcome, removed. In addition, the researcher considers the material of a literary composition"... everything that the poet has taken for granted - life relations, stories, cases, domestic situation, characters, everything that exists before, regardless of the story - if it is clear and difficult to tell in words"; the form is "the location of this material under the laws of artistic construction...» ${ }^{31}$ However, as far as music is concerned, there is nothing «ready» to exist «before» it, especially in the «intelligent»

\footnotetext{
${ }^{31}$ Выготский Л. Психология искусства. М.: Искусство, 1968. С. 187.
} 
and «coherent» form; such material of music can only serve itself as already known system of principles of artistic sign creation. And in the literature, if we take into account the ideas of the conditional polyphonic word of M. Bakhtin, the material is, from a certain historical moment of the evolution of verbal and genre forms, not only the actual reality, but also the existing experience of its literary reproduction, which causes an enhanced style self-dialogue (reflection) of literature. In other words, the material in art also includes artistic «building» material (genre, style, compositional, stylistic conditions), which is especially essential for the music being.

Thus, a first look at the psychology of arts - according to Vygotsky - reveals, as its really first reference point, the phenomenon of catharsis in its connection with the particular quality of artistic (including musical) experience arising from the «confrontation» of material and form the art work; however, first of all, it does not yet allow us to speak with confidence about the content and psychological role of artistic experience. Secondly, the question of the material of art in its relationship with form - especially in connection with music - remains controversial.

The development of the way to discover of the necessary completeness of catharsis and its artistic mechanism, that is, its form in art, is facilitated by another, broader, view of the «Psychology of Arts» (in its entirety), which, at the same time, leads to going beyond this work, to the other, already quite psychological works of Vygotsky, first of all to his «Educational psychology».

Vygotsky finds a particular figurative comparison for the artistic form, pointing out that the true art work resembles a «car heavier than air», which «falls every minute»; «it always selects matter as heavier than air as its material, that is, something that from the very beginning, because of its properties, seems to contradict the flight and prevent it from developing. This property, this weight of the material, constantly counteracts the flight, pulls down all the time, and only with the overcoming of this counteraction does the true flight

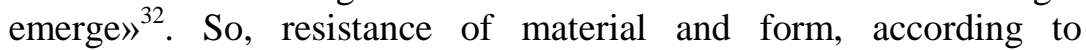
Vygotsky, can not be reduced only to affective contradiction, the

\footnotetext{
${ }^{32}$ Выготский Л. Психология искусства. М.: Искусство, 1968. С. 288.
} 
collision of opposing emotions or even to «contrafeeling», another term of Vygotsky); you need to explain how this emotional counteraction is overcome.

The preconditions for such an explanation arise when the scientist addresses the phenomenon of the unconscious; the concept of the unconscious becomes the second reference point, perhaps the main one, in the psychology of arts. After all, what is unconscious, according to Vygotsky? Here are the words directly addressed to this phenomenon: «Some great and indefinite need», «unclear but enormous forces», «something beyond that». "Any, somewhere, something» is vagueness, indistinctness, ambiguity of a place: as «the unconscious», speaking in Vygotsky's words, is «complete uncertainty»; «complete uncertainty» is the «address» of the unconscious. Vygotsky contrasts this «complete uncertainty» with the «complete certainty» of an art work. So he creates a central antinomy, one might even say, the central aporia of his psychology of arts: «the possible is the true». The complete uncertainty of the unconscious is the possible content of art, its possible material; the whole certainty, reality and effectiveness of an art work is the result of overcoming this material by constructing a particular form - and according to the specific laws of artistic composition.

Vygotsky's aporia is that we understand that the transition from the «complete uncertainty» of the unconscious to the «complete certainty» of art is possible, but we do not know how it happens. If we can observe processes that take place in art, and study them on the basis of the material and object subject "surface" that art really represents, then we cannot clearly answer the questions, what shifts, what processes occur in the unconscious, which of them encourage the formation of compositions that complete the creative process and are associated with the perception of artistic form. In the interval between these extreme positions - the uncertainty of the unconscious and the certainty of art - Vygotsky placed the phenomenon of catharsis, that is, the purification with the help of art, emotional lifting, the transition into higher spheres of consciousness, and so on.

There is much to say about the phenomenon of catharsis, giving it a great number of definitions, but the difficulties of the problem of catharsis lie in the fact that all these definitions form only the environment of the cell - the essential nature of the phenomenon, but 
none of them gets into this cell (center). It is a kind of «black hole», a semantic funnel, which tightens in itself, without allowing «to come to the surface» of conceptual judgments.

Vygotsky's following statement seems to us to be a concise confirmation of the above-mentioned and an indication of the further direction of thought: "The central idea of the psychology of arts is the recognition of overcoming material as an artistic form, or, moreover, the recognition of art as a social technique of feeling. We consider the method of this problem investigation as objectively analytical method, which precedes from the analysis of art, in order to come to the psychological synthesis - the method of analysis of the artistic systems of irritants",33. What does Vygotsky mean by «social technique of feeling», what art should be?

Referring to music, he notes that it «acts categorically», «revealing and bringing to life huge and previously suppressed and compressed forces (italics is ours $-A$. $S$.)», «an indefinite and enormous need for some action», itself «acts like an earthquake, exposing new layers to life ${ }^{34}$. Thus, music, as well as art in general, invokes the possibilities of man, by himself the most unknown, not realized, but predicted on a sensual level. At the same time, showing these possibilities in one form or another, it indicates the ways of their realization - transition into an effective plan. About the latter, there are the following words of Vygotsky: «Everything that art makes, it makes in our body and through our body ...»; art, therefore, is realized in the person and with his help; this is its main reality, which also gives rise to special possibilities of artistic influence: we recall that Vygotsky chooses Spinoza's words as the epigraph for all his work - «what the body is capable of, no one has yet determined...». Therefore, he states that «... art is the most important focus (cathartic focus - A. S.) of all biological and social processes in society, that it is a way of balancing a person with the world in the most responsible and critical moments of life»; it carries out «remelting of a man» and such «social technique (italics is ours $-A$. S.) of feelings... by which it draws into the circle of social life the most intimate and personal aspects of our

\footnotetext{
${ }^{33}$ Выготский Л. Психология искусства. М.: Искусство, 1968. С. 17.

${ }^{34}$ Там же. С. $320 ; 321$.
} 
being...» ${ }^{35}$. At the same time, art is “... the organization of our behavior for the future, its setting in advance, a demand that may never be fulfilled, but which forces us to strive above our lives for what lies behind it" ${ }^{36}$; therefore, it is able to become a precondition for meaningful discoveries - as discoveries of new possibilities of human consciousness - it is able to become a new «power over communication».

L. Vygotsky writes: «My thought was being created after the words of Spinoza... and after him I tried not to give into surprise, not to laugh, not to cry - but to understand ${ }^{37}$. In these words, he - as the co-author - quotes Spinoza's famous aphorism, with its help pointing to the starting point of the problem of comprehending the theory of the psychology of arts.

The same co-author's with regard to the direction of Vygotsky's thought, in our view, are the statements of some other philosophers. So, Aristotle's words stand out in this connection: "What the man is in possibility, that his creation is in reality", which continue Plato's view that «all that causes the transition from no-being into being is creativity" 38 .

Here is another thought that seems to distract from the mainstream of research, but actually clarifies it. Vygotsky writes: «All comprehension is incomprehension. That means, the processes that awaken in an alien language almost never coincide with those processes that occur in the speaker's head» ${ }^{39}$. This quotation testifies not only to Vygotsky's interest in the problem of comprehension, but also to his assessment of comprehension as a dialogical process, as well as his concern with the degree of unity in comprehension, as his possible common objects and goals.

Thus, the «social technique of the senses», which is art, is nothing more than the «technique of comprehension,» and this technique is dialogical because it is prepared by the general dialogical nature of comprehension. The «Psychology of Arts» contains quite perspective

\footnotetext{
${ }^{35}$ Там же. С. $331 ; 317$.

${ }^{36}$ Там же. С. 332.

${ }^{37}$ Там же. С. 18.

38 Там же. С. $279 ; 247$.

${ }^{39}$ Там же. С. 62.
} 
from this point of view three aphoristic remarks of Vygotsky: all comprehension is incomprehension; we do not remember words but thoughts; in the sculpture, the negro may be white. There is a deep interconnection between these three statements, which does not open immediately but the analysis of which makes it possible to understand Vygotsky's author's logic. This connection can be explained as follows.

On the one hand, Vygotsky believes that the closest causes of artistic effect are hidden in the unconscious; on the other hand, he notes that the art works themselves should be regarded as those objective facts in which the unconscious manifests itself most clearly, and therefore they become the starting point for the analysis of the unconscious. Thus, it simultaneously indicates the secrecy and objectivity of artistic experience. The nature and originality of the unconscious may, to Vygotsky's mind, be clarified on the basis that the processes that begin in the unconscious have a continuation in the mind and vice versa; the subconscious (in Vygotsky's terms subconscious is synonymous with the unconscious) is not separated from consciousness by an impassable wall; a live dynamic connection is made between the two spheres of consciousness, which «does not stop even for a minute»: «The unconscious influences our actions, manifests in our actions, and through these traces and manifestations we learn to recognize the unconscious and the laws that govern it» ${ }^{40}$.

Thus, the unconscious is accessible to «recognition», being the same sphere of consciousness as the conscious. However, at the same time, Vygotsky points to the impossibility of adequate unconscious (to the full extent of its content) knowledge about him, linking this provision with the thought of interpreting the sense of art: «Every conscious (hereinafter italics is ours $-A$. S.) and reasonable interpretation given by the artist or reader to a particular composition should be seen as a later rationalization, that is, some self-deception, some justification before one's mind, an explanation made after the

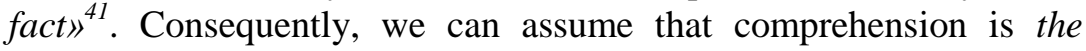
degree of representation of the unconscious in consciousness, that is, the depth of awareness that penetrates through the «layers» of

\footnotetext{
${ }^{40}$ Там же. С. 96.

${ }^{41}$ Там же.
} 
rationalization into the «thicker» pre-logical, verbatim; therefore, such representation occurs through a particular experience that opens the way of the self-dialogue of consciousness. It, however, remains not only an «internal affair» of consciousness, but seeks to be represented in some form, seeks to be expressed - and always achieves this only partly because of the difficulty of penetration, to the «stocks» of the subconscious - as to meaningful reserves of memory.

Vygotsky points out (in «Educational Psychology» ${ }^{42}$ ), that human memory has a special imaginative capacity, that is, the ability to create new sensual images and new ideas based on these images. Imaginative imagination, according to Vygotsky, is the memory of «non-former», something that in the human mind was not represented before. Feeling experience is not just the material of the unconscious; it is also the material that initiates the creative beginning of memory associated with the «play of imagination». Thus, in the scientific poetics of Vygotsky, a knot of concepts about cathartic exaltation that purifies the feelings, about banishing nature of higher emotions - as about the action of the unconscious, invisible, or felt, and about memory. As M. Bakhtin wrote, in art we learn about everything and remember everything, and according to B. Pasternak, history and art are children of one mother, memory.

Vygotsky emphasizes that in everyday life, the experiences we love through, the feelings that penetrate our consciousness, are not clear, certain enough, they remain the background for our actions and relationships; the same moments when they come to the fore are remembered as exceptional, not typical of everyday consciousness: when we are experiencing something so strongly that we notice the experience itself, it means either a very great joy or a significant distress, that is, something extraordinary: «Emotions are the points of imbalance in our behavior when we feel overwhelmed or triumphant over it» ${ }^{43}$. He regards artistic perception as a «secondary creative synthesis» of the emotional content of consciousness, due to the deepest need for the transformation of «lower types of energy, not

42 Выготский Л. Педагогическая психология. Под ред. В.В. Давыдова. М.: Педагогика, 1991.

${ }^{43}$ Там же. С. 249. 
wasted and those that did not found exit in the normal (everyday A. S.) activity of the organism to higher species...". One can call this the need to realize the deep sense of consciousness at its «top» levels, if we recall Vygotsky's words about «the collision of the unrealized subconscious desire with the conscious part of our behavior» as an urge for creative self-realization ${ }^{44}$.

Thus, in the artistic confrontation of emotions, the different directions of consciousness activity are expressed as a kind of «dialogue» of the awareness and subconscious, in which each participant «pulls» to its territory, to its own levels. This causes «affective contradiction». This contradiction becomes cathartic in nature if the movement initiated by both spheres of consciousness ends with a «sublime deepening» of consciousness, translates the meaning of the subconscious into the language of the conscious, and the logic of awareness enriches the semantic possibilities of the subconscious. The interaction of material and form, as the basis of artistic emotion, is carried out in such a way as a dialogue of thinking and memory - thoughts and sensory experience, namely, artistic experience is «changed state of consciousness»-but one that always has a positive sign.

«Top psychology», in the words of L. Vygotsky, seeks to discover what can and should happen to a person, seeks to show the way to the «liberated person» and to life as a «aesthetic rite», thanks to the penetration of the material shell of life and the exit for the subject restrictions of rationalization, penetration into the deep content of the artistic form - that which opens in this form, but never coincides with it. Thus, the idea of the "white negro" is addressed to discuss the specifics of the artistic form, its right to independence, to choose its own way, to not just reflection and reproduction, but the transformation of the world around. «White negro» - this is the sense that does not depend on the form in which it is enclosed, and which is enclosed in it insofar as we remember it and realize it...

Vygotsky clearly demonstrates that psychology as an independent science can exist only with the introduction of the concept of the unconscious. Finding in the unconscious the central concept of

\footnotetext{
44 Там же. С. $281 ; 282$.
} 
psychology, which allows to fill the gaps of the mental life, to establish its causal connections, he puts forward the basic thesis, in our opinion, for his teaching that the unconscious is potentially conscious, therefore, the unconscious can be considered as the initiatory beginning of consciousness, its «building material» ${ }^{45}$. Hence Vygotsky's approach to the psychics as an independent sphere of being, which eliminates the juxtaposition of being (material, object and social) and consciousness and the basic primary meaning of the first.

Thus, the process of awareness as a constant transition from the feeling reserves of the unconscious (deep memory) to conscious thinking forms (rational thinking and operational memory) is the primary and main material of art, namely, it acts as a special «language of consciousness», in agreement with contradictions and difficulties of the latter, therefore - a special kind of sign activity of man.

Thus arises a third contextual circle of consideration of the concept of Vygotsky's catharsis, which requires a new - a third look at his psychology of arts - already fully focused on his psychological writings. However, such a view provokes Vygotsky himself when he notes on the pages of «Psychology of Arts» that, as a whole, he leaves the solution of the problem of catharsis outside the scope of this book. It should be said that the final solution to this problem did not take place in other works of Vygotsky, despite the fact that he had found all the necessary for this issue and prerequisites; did not take place, as Vygotsky (like all psychological science of the first half of the XX century) associated the symbolic expression of the content of consciousness mainly with the processes of verbalization.

According to Vygotsky, the complete uncertainty of the unconscious is counteracted by the complete definition of consciousness expressed in sign forms, first of all, in verbal and conceptual rationalization and in the forms of literary creativity. The special role of verbalization as an awareness for Vygotsky is also explained by the fact that he explores (from the point of view of the art critic) the experience of literature, without resorting to specific

45 Выготский Л. Психика, сознание, бессознательное. Психология сознания. СПб.: Питер, 2001. С. 31; 44. 
forms of other forms of art, other, non-verbal, sign systems, although, as we have noted, he often calls for «musical», including in the literary work, but just as to the «comprehension», therefore, not dependent on the rational consciousness.

Meanwhile, criticizing traditional empirical psychology (psychophysiology) with its claims to objectivity and explanatory character, also describing phenomenological «eidetic» psychology with its efforts to become «understandable» by classifying the phenomena of mental life without addressing behavioral issues, Vygotsky sees the main disadvantage of these disciplinary areas in the identification of the mental with the conscious, in limiting the psychological content of the sphere of the directly conscious. Although in these areas the concept of the unconscious is used either in connection with the clinical pathology of consciousness (in the first) or in connection with the field of mystics (in the second). Compared to this, which he calls «old» psychology, Vygotsky finds the benefits of the teachings of S. Freud in that the Austrian researcher embarks on the «third path» of synthetic psychology, trying to describe the connections between the conscious and the unconscious, recognizing the right to exist and the importance of the last.

However, Freud proceeds from the facts of consciousness, moreover, facts that indicate the violation of its normal activity, that means, it goes from conscious plan of mental functioning of the subject to the unconscious, seeing in the latter pathogenic factor and reducing this factor to sexual attraction. As the latter is motivated by the human natural biological need, Vygotsky considers Freud's position as «tacit materialism», and therefore does not agree with it. At the same time, he emphasizes that Freud's theory remains one of the most complex concepts in the field of the unconscious, does not lose relevance, because this author reveals the paradox of the nature of the unconscious as real-unreal, unconditionally-conditional, reallypossible. On the one hand, the unconscious of Freud is quite real, because it causes obsessive actions, certain (painful) states of the human body; on the other hand, he cannot determine the actual nature of the unconscious (comparing it with the invisible «ether», with the mathematical concept «-1»), proposing a system of conditional 
concepts for describing it because of the inability to describe it as known facts ${ }^{46}$.

In our view, this is a very important aspect of the unconscious, not discussed by Vygotsky, namely: the unconscious is not amenable to «direct» description, reproduction; it finds its way into the life of culture in symbolic forms formed by consciousness for the sake of what words are not found; or in other words - symbols, that means, it is indirectly revealed. Therefore, Vygotsky was "dissatisfied" with the practice of rationalization as a "self-deception of consciousness". Generalizing the productive approaches of «old» psychology, he seeks the opportunity to present the unconscious in connection with the typological properties of mental phenomena, thus considering it as the general basis of these phenomena, and therefore as the conscious sub-basis (as to potentially conscious).

Agreeing that, as Freud said, the unconscious are precisely those ideas that are detached from the words (or not related to them $-A$. S.) and that in the verbalization there can be seen the distinctive sign of the conscious, Vygotsky leaves without an unambiguous assessment the sign of non-accountability of the unconscious due to its extraverbal rational consciousness and thinking. He only notes that «the faithful grain, which is laid in this connection between the unconscious and the non-verbal..., can receive true realization on the basis of dialectical psychology» ${ }^{47}$; the latter remains the "psychology of the future» not only in Vygotsky's time, but also today.

Thus, the question of accountability of consciousness, that is, the sign expression of the unconscious, which does not cancel its wordlessness, remains open. At the same time, it can be seen as a question of the specific sign of music; it is no coincidence that Vygotsky mentions the «music of tragedy» as its main invisible sense, its «atmosphere».

It is no coincidence that Vygotsky writes that, as a semantic phenomenon, «consciousness has a systemic structure (italics is

${ }^{46}$ Выготский Л. Психика, сознание, бессознательное. Психология сознания. СПб.: Питер, 2001. С. 36; 42-43.

${ }^{47}$ Выготский Л. Психика, сознание, бессознательное. Психология сознания. СПб.: Питер, 2001. С. 47. 
ours $-A . S$. $) \gg{ }^{48}$, that is, it is not one-dimensional; it contains different levels, spheres, states, and different modes of awareness - different forms of lingual expression. So, consciousness speaks to us not in one (verbal), but in many languages, one of which is the language of music.

In this regard, it should be noted that music really selects the most difficult material, seeking to express what is not amenable to verbal rationalization, although it is included in the artistic word as its secret knowledge, non-verbalized content. Therefore, becoming material (genre, style, compositional), «technique of the feelings», so, making the secret explicit - audible, music simultaneously becomes a cathartic transformation of sound matter - this is the specificity of its aesthetic form. "Overcoming material», according to Vygotsky's words, in music, as its "possible - real», is not deobjectificationextraction of content by means of form (compositional construction, as in a literary composition), but its objectification-attraction with the help of a new one (concerning the life series) content, namely, with the help of temporal ordering of the musical sounding, its new temporal duration, and its new spatial and sound expressiveness; this is how the sense is calculated by sound-image.

Based on the above-mentioned, we note that the interaction of material and form in music is in the different order, in comparison with literature: it is not an artistic composition that overcomes the sense of life events, but the event of sense that transforms sound matter into an artistically significant phenomenon. In other words: the aesthetic form of music, as self-sufficient, determines the logic of object and material expression, the compositional arrangement of musical meaning. Thus, music becomes an expression of the cathartic work of human consciousness - as an independent sphere of human being.

Strictly speaking, it is because of the originality and mystery of this sphere of being, the given reality of man, which, however, is always only offered - as a certain possibility, a musical expression, a musical catharsis has no need to be in the struggle and in overcoming

48 Выготский Л. Проблема сознания. Л.С. Выготский Собр. соч. в 6-ти томах. Т.1. Под ред. А. Лурия, М. Ярошевского, М.: Педагогика, 1982. C. $165-166$. 
that includes affective contradictions, which are characteristic of other forms of art.

The «difficulties» of meeting music with its material - in its two hypostases, internal-sense and external-sound - are mostly related to the finding of their formal semantic and content and subject relations, so, their union, merger. Moreover, the first and main vocation of musical expression, as an expression of semantic content, is determinative in the form-creating aspect. In this way, the struggle for material in music turns into a struggle for one's own material as for the right of consciousness to express itself in the language which its semantic construction expects from it.

In this way, musicological thought can complete that direction of study of the cathartic nature of art, which was started by L. Vygotsky in «Psychology of Arts», supported by the content of his other psychological works; it is formulated as a theory of the cathartic activity of the human consciousness as a whole.

\subsection{Psychological foundations of musical thinking and semantic principles of musical language}

The category of musical thinking is one of the leading in ordering the formal, logical and semantic qualities of musical art. Its main feature is the transitivity and the medial-transfer function in the sphere of realization and the boundaries of the process of thinking, as able to organize the interaction (qualitative unity) of consciousness and lingual significant environment of musical creativity. Therefore, this category always remains the subject of interdisciplinary dialogue, even forming its own specific conceptual interdisciplinary branch, the main components of which, apart from musicology, are phenomenology in its noological direction and psychology of arts.

In recent years, it has been affirmed that the musicological concepts of this phenomenon (process) emerge from the study of the nature of creative thinking - or the creative nature of thinking - as one that subordinates biological factors of human existence to social 
cultural and semantic needs, thus testifying to the advantages of man as a socio-historical creature over biological environment $\mathrm{t}^{49}$.

Of course, not only musical thinking, but any thinking manifestation of human consciousness attests to its sign organization and semic origin, that is, the correlation of the sign and semantic beginnings of consciousness. More than that, there is no separate form of musical thinking; the very concept of it is neologism, because it indicates specific dynamic and qualitative indicators of the process of perception and action associated with musical creativity. Musical thinking, or as it was defined by M. Bonfeld, thinking with music, is subject to those patterns of consciousness functioning that determine its creative (autopoiesis) resources ${ }^{50}$.

Therefore, it is fair to say that human thinking, like human consciousness, is not divided into musical and non-musical, although, indeed, certain processes occurring in consciousness provide appropriate modes and structures of explication, sign expression, and broadcast. Conditions of musical perception and influence also become conditions for thinking about music - musical means; they are the closest to the biodynamic and sensual fabric of consciousness, in its constant movement and search for internal balance. The figurative imagination becomes the argument for the latter, generating figurative and cognitive models. Conceptual models of musical sounding - logical instruments of music itself - are formed from the latter.

Musical thinking is preceded by the contamination in the consciousness, in its reflexive sphere (V. Zinchenko ${ }^{51}$ ) of those meanings which accumulate and crystallize immanent sensual qualities, actualize intentional properties. Thus, preconditions for combining methodological levers of psychological and musicological approaches and attracting noological concepts to them are avoided. After all, it should be recalled that noology, leading to modern

49 Кирнарская Д. Психология музыкальной деятельности. Теория и практика. М, 2003.

50 Бонфельд М. Музыка. Язык. Речь. Мышление. Опыт системного исследования музыкального искусства. СПб., 2006.

51 Зинченко В. Миры сознания и структура сознания. URL: http://development2005.narod.ru/books/zin.htm 
science from the time of Aristotle, is the doctrine of the impregnation of all existing (existential) impulses of the Mind, in which the human speculative and worldview experience appears at the same time constant and mobile, free and limited by self-indulgence, generalizing and individualized, fleeting and eternal. The antinomies of the noological plan of human existence only reproduce the contradictions on which human subjectivity is based as a necessary component of cultural and semantic reality. Therefore, it is understandable that the phenomena of thinking - sense - awareness are interconnected, among which the basic is the sphere of consciousness, which provoked to lingual expression (self-expression).

According to S. Rubinstein, out of language there is no consciousness; language is a key condition for awareness. Rubinstein, like most other authors, saying this, implies verbal language, verbalization, which can be objectifies in a word form. To what extent is the problem of «language of consciousness» fundamental for musicology? Is it legitimate and in what aspects does the problem of "musical consciousness", which in the context of the marked psychological approach, become the problem of "music as a language of consciousness"?

First of all, we should try to answer the question: Is there enough consciousness of one language, even if it is generally recognized and multifunctional as verbal? Already a variety of subject orientations of words, including focus on «untold» and «secret», which contributes to the growth of suggestiveness, rhetoric, indirectness and so on, indicates the limited form of verbal and lingual expression that the word is trying to overcome.

According to G. Gadamer, «language is not identical with what it is says in it...; ... The lingual form is not simply not accurate and does not simply need improvement - it, no matter how successful it is, never has time for what it awakens to life. Because deeply within the language (here and more italics is ours $-A$. S.), there is a hidden meaning that can only emerge as a deep foundation of meaning that immediately escapes as soon as it is given any form of expression ",52. Gadamer finds the criterion of the functional feasibility of language

52 Гадамер Х.-Г. Семантика и герменевтика. Актуальность прекрасного: Пер. с нем. М.: Искусство, 1991. С. 65. 
in its orientation to sense, which makes it necessary to point out the incomplete detection of sense in a word, the «non-accountability» of a word to the whole scope of understanding; although the latter for Gadamer is inseparable from the verbal and lingual form. He comes up to the process of comprehension as a "lingual event" $"$, but notes that this event is not the whole event of comprehension. At this moment of his thoughts, Gadamer concludes that he reveals the closeness of his research position to L. Vygotsky's theory.

So, Gadamer writes: «If, by grasping the phenomenon of language, to go not from isolated expression (meaning or compositionally delimited set of meanings $-A$. $S$.), but from the unity of our worldview, the unity that represents life in dialogue, it will be easier to understand why this phenomenon is so mysterious, so attractive and at the same time inaccessible. Language is a deep unconscious phenomenon, but it is performed by conscious beings" ${ }^{\text {" }}$. "Mysteriousness»,, "attractiveness" and "inaccessibility", thus, is conditioned by its attempts to present the unconscious, to define it, thus defining the place of comprehension in the consciousness. Therefore, the verbal manifestation of comprehension, «... always has difficulties, obstacles to establishing consent. The intense effort of the will to comprehend begins with the feeling of being confronted with something distant, which is provoking, disorienting. The Greeks had a great word to indicate a situation where we understand to meet an obstacle, they called it atopon. This means, in fact, «deprived of space», that is, what does not fit into our expectations and is therefore confusing» 55 . The connection between comprehension with the unconscious and the initiating role of the latter in the process of comprehension cannot be made clearer...

Gadamer's proposed «hermeneutical circle» of comprehension from a psychological point of view extends to the boundaries of the processes of awareness - from the boundaries of the process of cognition as concrete and effective in its verbal and logical conceptual forms. Probably the particular limitation of the latter made

${ }^{53}$ Гадамер Х.-Г. Язык и понимание. Актуальность прекрасного: Пер. с нем.

М.: Искусство, 1991. С. 44.

54 Там же. С. 59.

55 Там же. С. 45. 
Rubinstein notice that «not only does man's awareness of objective reality not exhaust everything that exists, but it does not encompass all that directly surrounds and influences man» ${ }^{56}$. Once again, we are convinced that the problem of comprehension borders on the problem of sense, and the latter, as related to the issues of awareness of sense, is part of the problem of consciousness, and therefore the problem of the unconscious.

In this form, this problem requires recognition of two circumstances: in the words of L. Vygotsky, «consciousness as a whole has a semantic construction ... The sense-forming activity of meanings leads to a certain semantic definition of consciousness itself»; "Consciousness has a systematic structure" (hereinafter italics is ours - A. S.)" ${ }^{p 7}$, that is, it is not one-dimensional, it contains different levels, spheres, states, and different modes of awareness different forms of lingual expression.

So, we would say, consciousness speaks to us not in one language but in many languages. The difficulty of comprehending in this case is explained by the fact that it requires a «language of unspeakable», special «musicality» of thinking, the concept of which becomes synonymous with the concept of comprehending completeness in Vygotsky's poetics. The inequality of the processes of awareness and comprehension is also evident; the first represents the level of knowledge with fixed, stable meanings that can alienate from the subject, move from the sphere of the unconscious to the accountable sphere of consciousness - «float» to the surface of sense. The other is caused by the boundary of the unconscious and the comprehension associated with the search in the deep realms of consciousness, with immersion in their hidden possibilities, which reveal the variability of sense due to its inaccuracy with meaning, with the activation of the unconscious as the most general boundaries of consciousness by means of consciousness, with the extension of comprehension sphere with the help of "ray of consciousness" or "light spot" from a

${ }^{56}$ Рубинштейн С. О сознании. Психология сознания. СПб.: Питер, 2001. С. 52.

57 Выготский Л. Проблема сознания. Л.С. Выготский Собр. соч. в 6-ти томах. Т.1. Под ред. А. Лурия, М. Ярошевского. М.: Педагогика, 1982. C. 165-166. 
"lantern" (I. Pavlov), which can be defined as "memory of knowledge".

If the first process has a predominantly one-sided orientation, then the second requires dialogicity as a self-dialogue of the subject made in the space of sense. This dialogue is implemented as a contradictory interaction of sense and meaning (meanings). In verbal form, this leads to expression duality. The response to Gadamer is Vygotsky's opinion: «Every language is an allegory» (has a back opinion) ${ }^{58}$.

Thus, the psychological aspect of the phenomenon of meaning is defined - it is one of the leading in modern conceptions of consciousness. This phenomenon is associated with semic (later called semantic by him) analysis of Vygotsky word, which he considers as the only adequate method of studying the systemic and semantic construction of consciousness ${ }^{59}$. He defines meaning as a way from thought to word, emphasizing the inequality of meaning with both word and thought, since «meaning refers not to thinking but to all consciousness.» The meaning does not coincide with the logical construction (it is wider than it), but it does not reach the volume of the whole meaning, it is not equal to it, because "the meaning is assigned to the sign. Sense is something that enters into a meaning (the result of a meaning) but is not fixed by the sign"; «Meaning remains frozen, sense changes» ${ }^{60}$.

Thus, Vygotsky views the meaning as a kind of «psychological instrument» (in its terminology) - artificial adaptations aimed at mastering one's own mental processes, the internal, though socially conditioned, formed, technique of consciousness ${ }^{61}$. The way of meaning from thought to word is the way of understanding - the creation of sense. Vygotsky views it as such a «work of thought» which is a transition from the feeling of the task of comprehension through the construction of meaning - to the unfolding of the thought itself (which is, therefore, felt or premonition); and this is the way

58 Выготский Л. Проблема сознания. Л.С. Выготский Собр. соч. в 6-ти mомах. Т.1. Под ред. А. Лурия, М. Ярошевского. М.: Педагогика, 1982. С. 162.

${ }^{59}$ Там же. С. 167.

60 Там же. С. $165 ; 160$.

${ }^{61}$ Выготский Л. Инструментальный метод в психологии. Л.С. Выготский. Собр. соч. в 6-ти томах. Т. 1. М.: Педагогика, 1982. С. 103-108. 
from «obscure desire to indirect expression through meaning that leads to the improvement of thought in the word ${ }^{62}$.

What Vygotsky calls in «Psychology of Arts» as «emotional thinking» is connected to any work of thought, to the work of consciousness as a whole. The importance of such work for the subject is revealed in the following words: "What I think of things that are beyond me changes nothing in them, and that I think of affects, that I put them in other relationships to my intelligence and other instances, changes a lot in my mental life. In other words, our affects operate in a complex system with our concepts..."63

Due to the connection with «emotional thinking», meanings are «communicating meanings» according to the «scheme»: man - man, man - thing - man, but not «man - thing», that is, have a communicative and dialogical nature. Hence their function of generalization as mediated communication, which gives rise to a dual functional orientation of the sign (communication - generalization, generalization - mediated communication). Vygotsky derives the main law of meanings: what form of communication is, such is the generalization. Thus, he allows to find the way of musical semantics - generated by the «emotional thinking» of musical meanings - as a transition from the real conditions of musical creativity (performing genre forms) to the conditionality of compositional decisions, and in musical text - correlation of generalization levels of musical meanings, and these levels represent the style and the stylistic consequence of the separation of communicative genre forms of music (forms of communication with music). The above-mentioned also allows to find certain "sets of meanings" in the textological levels of music, both levels of musical comprehension, style, and at the same time mobile-changeable conglomerates of musical and lingual creations that enter both within themselves and in relation to each other in complex dialogical forms of equivalence and transitivity, thus organize the transmission of the semantic content and the symbolic nature of such transmission.

${ }^{62}$ Выготский Л. Проблема сознания. Л.С. Выготский. Собр. соч. в 6-ти mомах. Т.1. М.: Педагогика, 1982. С. 162.

${ }^{63}$ Выготский Л. О психологических системах. Л.С. Выготский. Собр. соч. в 6-ти томах. Т.1. М.: Педагогика, 1982. С. 126. 
Thus, the connection of the unconscious is revealed with the sensual subtext (or context) of all work of consciousness. Vygotsky insists on such possibilities of this work, which define «peaks of personality», calling his psychology «top», not «deep». The latter appeals to such levels, «changed states» of consciousness, which demonstrate pathogenic factors that suppress the psychics, «descent», rather than the rise of the conscious work of subject; it makes treat the unconscious with distrust and fear. Vygotsky also interprets the sublimation phenomenon differently, not as bringing out the negative processes of the subconscious, but as a creative transformation of the «energy» of the unconscious, the transformation of lower energies into higher kinds. According to him, "our capabilities outweigh our activities...", causing «the collision of unrealized subconscious desire with the conscious part of our behavior... For the unfulfilled in life there are only two exits - either sublimation or neurosis» ${ }^{64}$.

Thus, the meanings have an "understanding" side that addresses the subconscious as the realm of meaning generation. This sphere is defined as sensual - but as a special sensual transformation of consciousness, the achievement of «the top possibilities of changed states» - the achievement of catharsis.

From this point of view, a new content of concepts introduced into the scientific life by A. Leontiev, such as «sensual fabric of consciousness», «personal sense» in their projection to «meaning», opens. Leontiev uses these concepts as a trinity, but significantly narrows the functions of «meaning» in comparison with Vygotsky. In his view, meaning is «the ideal form of the subject world existence, its properties, relationships and connections, transformed and collapsed into the matter of language»; since meanings depend on social practice, they are «not psychological» ${ }^{65}$.

Limitations of A. Leontiev's theory are overcome in modern psychological works, which carry out on their pages the «return» of L. Vygotsky's thoughts and thus «re-examine» the trinity of the sensual fabric of consciousness - meaning - personal sense. Thus,

${ }^{64}$ Выготский Л. Педагогическая психология. Под ред. В.В. Давыдова. М.: Педагогика, 1991. С. 282.

65 Леонтьев А. Деятельность. Сознание. Личность. Психология сознания. СПб.: Питер, 2001. С. 78. 
V. Petrenko considers it possible to speak about the sensual fabric of meanings and personal senses, considering that it is this «fabric» that defines the imagery of not only «vital» but also scientific abstract concepts, that is, the latter - as meanings - are projected to sensuality, and have a certain «subjective image» ${ }^{66}$.

Based on Vygotsky's opinion that the degree of meaning development is determined by the nature of its system organization, the presence of relation chain of this meaning with others, first of all, the conceptual chain, the author concludes that there is a need for the theory of types of relations, the theory of «generalized predicate», also as a theory different types of generalization. The latter forces us to refer to meanings as forms of generalization "not only in the form of concepts, but also in a system-organized figurative plane - to analyze the form of the existence of non-verbal meanings in human consciousness $^{67}$. The question is to ask about a fundamentally different, in comparison with verbal and conceptual, «psychological structure» of meaning, about other functions of non-verbal meanings, about non-verbal semantics. In connection with this semantics, the researcher considers it necessary to introduce the concept of «psychosemantics of consciousness», interrelated with non-verbal «iconic, symbolic» systems of meanings.

V. Petrenko interprets the term "iconicity" in the semiotic plane rather loosely, identifying "iconicity" and symbolism, which is a justified finding of a possible common feature of iconic and symbolic signs: preserving relations with the displayed object. However, the difference between the objects for the iconic and symbolic reflection, as well as the degree of dynamism of the named characters is not taken into account, but in this case it is not so important. More importantly, the author notes that "the iconic semiotic systems to which we refer to non-verbal communication, painting, architecture, ballet, music, etc., are characterized by the fact that the expression plan and the content plan are interdependent and purely structural methods cannot fully reveal the content of the iconic sign"; «For the iconic semiotics the oppositions, "meaning - personal sense" and

${ }^{66}$ Петренко В. Проблемы значения. Психосемантика сознания. Психология сознания. СПб.: Питер, 2001. С. 172-173.

${ }^{67}$ Там же. С. 178-179. 
"knowledge - art", they appear to be withdrawn"68. Thus, in this system, meaning is capable of initiating a «personal meaning» (experience of understanding), to create one's own object and to redefine external data of perception. However, the author does not indicate why this is happening, and in our opinion, in the cited work this deficiency is explained by the absence of questions about the mnemonic nature of symbolic signs, about memory as a tool, an «instrument» of meaning formation. Each mnemonic function has its own lingual form. But in non-verbal, including in musical, communication, they take a leading and especially deep, «directorial» organizational role, because this system of communication generalization in meanings requires immediate empathy, immersion in meaningful linguistic material, changing the everyday state of perception, the transition to another, in comparison with everyday life, reality, or rather, another dimension of this reality - closer to its semantic intentions. Without this, nothing will happen - neither with the perceiving subject, nor the meaning offered to it by the sign, so the act of communication will not take place, meaning will not find its way from sense to sign. V. Petrenko notes, however, that the study of symbolic meanings requires the active modeling (researcher) of emotions and images of the communicator (even if not present in person), which, in our view, is a necessary side of semantic analysis. The final conclusion of this author is connected with the call to synthesize objective and subjective methods of analysis, since in the case of symbolic semiotics the main subject of analysis becomes not the text but «real verbal and non-verbal behavior of the person», that is the person himself ${ }^{69}$.

Let us note another important achievement of the psychosemantic approach on the way to possible gradations of the semantics of nonverbalized meanings - predicted by Vygotsky's «justification» of «changed states of consciousness» (CSC in psychological nominations). These states are no longer characterized as destructive (though they may be), but as "other constructive" - as changes in the "form of categorization of the subject, accompanied by the transition from socially normalized forms of categorization to other non-

\footnotetext{
${ }^{68}$ Там же. С. $181 ; 180$.

${ }^{69}$ Там же. С. 182.
} 
standard ways of ordering internal experience and experiences; this process involves the transition from the dominant support to verbal and logical, conceptual structures to reflection in the form of visualsensory (pre-verbal) images (italics is ours $-A$. S.)",70. For these states, the only and special language becomes the «language of experience» - the "language of understanding», because it is an extremely intense, holistic experiences that integrate consciousness, bringing it to a state of new spontaneity; they open up «new layers of mental reality».

Summarizing the above-mentioned, we note that in the context of the works of Vygotsky the trinity of «meaning», «sensual fabric of consciousness» and «personal sense» is revealed as a dialogical triad of functional (from the psychological side) basics of memory (owning the meanings depending on past experience of perception and experience) - a positive sensual lifting of consciousness, utterly expressed in a state of love (the higher positive state of accepting the world as a subject, that is, empathy with it as «its», removing the boundaries in experience) change of consciousness due to shift of its internal borders - play with borders of conscious - unconscious.

Art is always an experience of «changed states of consciousness», due to its special significance in the phenomenon of memory, first of all, as a cognition, then - as a transformation in memories, as Bakhtin pointed out, saying that «in art we learn everything and remember everything"... This Bakhtin's "everything" deserves special attention; it holds the key to the mystery of creative memory, which brings together the past and the future in the «endless present» of an art work. Thus, in music it becomes possible to have a prognostic dialogue as a kind of "memories of the future", and a dive into the past - a "future memory of the past"; between these extreme poles of music over time there take place all other forms of musical dialogue as cultural memory.

Artistic musical memory is not limited to logical possibilities just like «memory of understanding» (as opposed to logical «memory of knowledge»). This is connected with the division of memory into

${ }^{70}$ Кучеренко В., Петренко В., Россохин А. Измененные состояния сознания: психологический анализ. Психология сознания. СПб.: Питер, 2001. С. 410. 
memorial and mnemonic (familial) directions ${ }^{71}$. At the heart of these directions, as their psychological implication, there are the reproductive and imaginative forms of memory - primary memory, inseparable from perceived material, assigned to it, which identifies with it the act of perception-assessment - and - conscious special, internally motivated reproduction associated with the processing and separation of impressions, estimates from the primary source material. In other words, it is the memory of the «former», it is imitative, and the memory of the «non-former», which turns on the imagination $^{72}$.

In its second capacity, memory develops «the ability to forget unnecessary», that is, to make a choice of material for the formative work of memory - unlike primary memory, which by virtue of its main property - plasticity - keeps all traces of influences, all impressions, becomes a kind of «plant living ornament». The transformation of this ornament into a background for one's own «figures» of consciousness takes place in the process of the development of the human consciousness from its infant state to the adult. According to Vygotsky, a symptom of growing up memory is that «if for a young child to think is to remember, them for a teenager to remember is to think» ${ }^{73}$. In other case, from which the mechanism of creative memory grows, thinking is the basic principle in the functioning of memory, consciously directing it in the desired way. The involuntary distortions of reality (when reproducing in "primary" memory) become a conscious, meaningful and purposeful play of fantasy in the creative mnemonic form of memory. Vygotsky even notes that $« \ldots$ between the play and the imaginative behavior one can draw a sign of equality» ${ }^{74}$. Such a play is a way of «knowing from the non-former,» that is, «lying deep and often remaining undetected for consciousness,» though rooted in reality. The point here is not in the

71 Самойленко А. Музыковедение и методология гуманитарного знания. Проблема диалога. Одесса: Астропринт, 2002.

72 Выготский Л. Педагогическая психология. Под ред. В.В. Давылова. М.: Педагогика, 1991. С. 181-183.

73 Выготский Л. Проблемы общей психологии. Л.С. Выготский. Собр. соч. 8 6-ти томах. Т.2. Под общей ред. В. Давылова. М.: Педагогика, 1982. С. 394.

${ }^{74}$ Выготский Л. Педагогическая психология. Под ред. В.В. Давыдова. М.: Педагогика, 1991. С. 186. 
weakness of impressions or forgetfulness, but in the fact that the main thesaurus of humanity is formed in the unconscious mental sphere; first of all, these are the «lowest» instinctual trains and the "highest» semantic desires; the first find themselves there because of their biological nature automatism, the others - because of the distorted, conditionally-substantive transcendental, that is, metaphysical essence (low and high energies in Vygotsky's interpretation). A way of revealing the deep content and transforming it into the top, that is, the integration of all the "memory» material of consciousness in the higher levels, as a kind of «convergence» in the consciousness connected with the work of emotional imagination, experiences. They give the «non-former» (and unforgettable) real character, make a real "connection with reality» ${ }^{75}$, and create the effect of reaching the desired spheres and «peaks».

Experience is the mediator between memory and playimagination. Thus, there arises the unity of memory, which is conditioned by the nature of memory - the exalted experience - of figurative play, as the dominant unity of human consciousness. As the reason for this dominant unification Vygotsky finds the need for the growth of conscious human forces, the realization of life as a "aesthetic rite», in the evolution of consciousness towards the «liberated man»- a higher socio-biological type of man: «Man seeks to capture his own feelings, raise his instincts to the top of the consciousness, make them transparent, ... thereby raising himself to a new stage ${ }^{76}$. In musical creativity, which relies on a specific nonverbal symbolic system of meanings, "understanding" and "knowing" consciousness reveal a strange closeness, almost an identity, which causes the perception of music as the only artistic form, as "relevant and beautiful" (G. Gadamer).

\footnotetext{
75 Там же. С. 183.

${ }^{76}$ Там же. С. 372.
} 


\section{SECTION 2 \\ LEADING CATEGORIES OF PSYCHOLOGY OF MUSICAL ARTS}

\subsection{The category of spirituality and the concept of artefact in the psychology of arts: the musicological aspect}

Without fear of exaggeration, we can say that throughout the history of human thought, the concept of «spirit» and its derivatives (spiritual, spirituality) were accompanied by attempts to comprehend, to give to the names the level of being, which, being the highest for man, at the same time does not belong to him - it is beyond the limits of vital human capabilities, makes them aware of their inevitable limitations. But it is this circumstance, oddly enough, that has defined a completely positive attitude to the beginning, called as spiritual - as to a life-giving, literally charitable source. Truly, about the spiritual is either good or nothing, and this becomes his first enigma and creates the first difficulties for it to become aware of; another mystery is this realization: being an inaccessible divine attribute, the spirit, however, manifests itself as a wholly human relation to it, as a property of human consciousness.

If the «spirit» can be addressed to the divine principle, to recognize its inaccessibility and incomprehensibility, then «spirituality» as penetration of the spirit into human life, the attribute of the already human world requires explanation - as an expression of responsibility for the attempt of man to go beyond his life restrictions, for the desire of «being in the spirit». This can be explained by the words of M. Bakhtin: "Special responsibility is needed...; it cannot be created directly in the divine world, but this specialization of responsibility can only be based on a deep trust in a higher instance that blesses culture (hereinafter italics is ours $-A$. $S$.), the trust that another - higher - is responsible for my special responsibility, that I am not acting in a value void. Outside this trust, only an empty 
claim is possible» ${ }^{77}$. M. Bakhtin points to the central problem of the human being - the problem of value and semantic justification of human efforts to assert himself in this world, to unravel the fate he was given. Among the many known exonyms («external names») of the person, one is powerfully at the forefront: «a semantic person», that is, a person who conceives and embodies meanings, and therefore, in Bakhtin's words, «is remembering, loving and understanding ${ }^{78}$, capable of «playing» the «whole event» of sense, creating the «whole play of poetic symbol» ${ }^{79}$. Thus, the concept of «spirituality» gives rise to its own range of meanings, capable of forming an independent conceptual series: value, sense, symbol, understanding, memory, love, play. However, these related concepts do not save the ontogenesis of spirituality from mystery. Today's definitions of spirituality do not save from it, though they claim the final categorical result.

Summing up the most accepted approaches, it must be said that contemporary authors (philosophers, cultural scientists, sociologists, psychologists) most often find in the spirituality an integral category expressing moral and axiological, theoretical and cognitive, artistic and creative activity of man; the way of human self-building and finding his life vocation; a person's choice of his own image, his destiny and social role. Philosophers tend to define spirituality as the person's attitude to world ideals, general human and national ideas, and the degree of human involvement in general human, cultural, world (universal) values. Psychologists emphasize the importance of spirituality as a special essential characteristic of subjectivity (subject relation), produced by the subject of activity after the mechanism of reflexive generation. These and some other, similar, attempts at defining spirituality, if used in the words of a Chinese philosopher of the XII century (addressed to another Chinese philosopher, Xun Kuang), give the impression of a person trying to scratch his foot through his boot - they are so turned away from the general

77 Бахтин М. Автор и герой в эстетической деятельности. М.М. Бахтин. Эстетика словесного творчества. 2-ое изд. Сост. С. Бочаров; прим. С. Бочарова и С. Авериниева. М.: Искусство, 1986. С. 189-190.

${ }^{78}$ Там же. С. 70. 
principles of human life. Undoubtedly, spirituality is an interdisciplinary category, not completely belonging to any field of humanitarian knowledge; most likely, it should be attributed to the field of epistemology of culture - in that sense, the doctrine of the a priori foundations of different historical types of culture, which we find in the works of M. Foucault. However, what determines such its position?

Two points in contemporary evaluations of the phenomenon of spirituality deserve special attention: firstly, the possibility of its manifestation in a sign symbolic form - and only in this way; secondly, as the article in the modern Ukrainian philosophical dictionary points out ${ }^{80}$, its connection with existentials (in this case it is «faith, hope, love»). One thing is undoubtedly connected with another - and for these reasons.

Iranian philosopher of XI-XII centuries Abu Hamid Al-Ghazali calls the spirit «a Divine commandment, the essence of which cannot be understood by most minds and judgments; but he, considering the meaning of the human heart, calls the «spirit» a divine gift, which is the essence of man: it is that which "comprehends, knows, realizes in man»", «" «speaks, controls, rebukes and needs»" spiritual in man is the work of consciousness as the only instrument that resonates in response to the movements of the world, first of all, in response to the movement of time - in time, with time. Most clearly, this understanding of the spirit is evidenced by the words of St. Augustine: "Time exists only in our soul. The past is in memory, the future is in waiting...; the essence of the present is contemplation...; in you, my soul, I measure time. The impression of passing by remains in you, and its - is what is now, I measure, not what has passed and left it. I measure impressions by measuring time...; it seems to me that time is nothing but a certain length. But I

${ }^{80}$ Філософський енциклопедичний словник. Гол. ред.: В. І. Шинкарук; ред. кол.: Є. К. Бистрииький, М. А. Булатов, А. Т. Муратов та інші. К.: Абрис, 2002. C. 179.

81 Таранов П. Анатомия мудрости. 120 философов: В 2-х тт. Симферополь: Таврия, 1996. - Т. 1. С. 575; 574. 
do not know for sure the extent of what, although it is unlikely that it would be anything other than the length of the spirit itself" ${ }^{\prime 2}$.

It is time that acts as the principal existential of man and the human community; relationships over time form deep «impressions»- experiences that are saved in memory. M. Bakhtin wrote about this kind of experience: "Experience is a trace of sense in life...; from within itself it lives not by itself but by this sense of being removed and caught...; it becomes a value that is considered in addition to the meaning of sense, becomes a valuable form, and sense becomes a content. The sense is subordinated to the value of the individual existence of the mortal flesh of experience ${ }^{83}$. Becoming a «contemplative value», brought out by the effort of awareness of sense, experiences of this kind and constitution of spirituality, condemning it to an indelible duality - the contradictions of selfconsciousness, which are caused by the relation of man with time. E. Fromm defined this duality as existential dichotomies, the main of which is the dichotomy of life and death, and derivative from it and the most painful for the human being is the contradiction of the short life expectancy of man and the historical generic time of mankind: «... A person could participate in the process of historical human development only if the life time of the individual equals the life time of all mankind. Human life, which begins and ends at random moments in the historical development of mankind as a whole, is in constant conflict with the potential assigned to each individual, which is to realize all its possibilities" ${ }^{\prime 4}$. A person cannot eliminate existential contradictions, Fromm writes, but he may react differently to them; «he can fill his life with sense», «become happy through the full realization of the gift, which is a human feature - the gift of reason, love, and work for the benefit of man and for the sake of man" ${ }^{\prime 85}$. Thus, spirituality as a self-contradictory dichotomous phenomenon reflects the antinomies of human comprehension of time, and rises time to the level of the main value, to hold and save

82 Там же. С. 471.

83 Бахтин М. Автор и герой в эстетической деятельности. М.М. Бахтин. Эстетика словесного творчества. М. : Искусство, 1986. С. 108.

${ }^{84}$ Фромм Э. Человек для себя. М.: АСТ; Мн.: Харвест, 2006. С. 62-63.

85 Там же. С. 67-68. 
which, even beyond the limits of individual physical existence, to ensure infinite duration of which as «the duration of the spirit» becomes general human goal. After all, in Lotman's words, if a person wants to live, then humanity seeks to survive, and this existential need of the human community directly, though paradoxical ways, depends on the semantic orientation of the individual" 86 .

No wonder considering the content of the original antinomies of the human microcosm, P. Florensky tells the two initial positions of the personality (human consciousness): «the wish of boundless Reality and the demand for unconditional Truth». The first is related to the "limitless expansion of its titanic basis" with the "overcoming of every norm, every sense"; the second means «the steady liberation of oneself from all reality, every being». The first leads to the basis of Sense as such, to "encroach" on it and see the "Supreme Meaning" (we would say - the Spirit) as "the Might itself". The other leads to the basic Reality in order to demand from it the evidence of its rights for being and to make sure that the «Supreme Reality» (we would say - spirituality) is the Sense itself. The first ends with the absolute victory of the titanic (being, real), but also the absolute defeat: because the peak of truth of the Earth is the truth of Heaven and man, «... having filled up the affect of its titanic anger, it illuminates and reconciles». The other ends with the recognition that the Supreme Reality, as an absolutely solid point of being, is the Absolute Sense, because the truth of Heaven is the same truth of the Earth that man struggled with: "Then the thirst for the spirit will be extinguished and despair will reap the joy of finding the Truth of reality. Both ways are needed» ${ }^{87}$.

Thus, Florensky, in his own terminology, describes the dual movement of human consciousness - to and from the spirit; the point of intersection of these two ways, the moment of meeting a person with himself as with a spiritual - feeling and thinking - being makes sense - the Absolute sense that gives rise to the "great symbolics» of culture. The incarnation of meaning as the main

86 Лотман Ю. Семиосфера. Культура и взрыв. Внутри мыслящих миров: Статьи. Исследования. Заметки (1968-1972). СПБ.: Искусство, 2000.

${ }^{87}$ Флоренский П. Из богословского наследия. Богословские труды. Т. XVII. M., 1977. С. 142. 
witness of human spirituality into the artistic form, that is, its representation by means of art, leads to the isolation of the phenomenon of artifact.

Artifact is not yet a sustainable art concept, as it is more a part of anthropological terminology. Contemporary art criticism more and more often meets with the need to test such concepts, and this approbation is not simply an adaptation of ready-made conceptual forms. Rather, it is carried out as an addition, even a substantive modification of some categories. These include a category such as «artifact», which departed from the lexical range of traditional anthropology and found a new meaning in the works of aesthetics, semiotics, cultural scientists, and finally, art critics. Perhaps it is the updated relevance, the widespread use of the concept of artifact that led to its obtaining of terminological instability. The contradictions in the interpretation of the phenomenon of artifact are explained by the fact that, on the one hand, there is still no unified «theory of artificial object», and on the other - artifacts of culture are characterized by a high degree of «symbolic and semantic variability»" ${ }^{88}$.

In addition, the artifacts are diverse and each of them is a complex functional creation, which is reflected in the definitions of the phenomenon adopted today. Actually, it is possible to find in it «any artificial formation, both physical and ideational»; "Abstract carrier of cultural semantics»; «Interpretive embodiment of any cultural form in a particular material product, behavioral act, social structure, informational message or evaluative judgment»; art works in their unique form (author's opuses), quotations and borrowings, remakes, performance of musical compositions; research, critical, philosophical and other texts, even personal judgments about the cultural phenomenon of individuals ${ }^{89}$. The resulting expansion of the concept leaves the impression of the arbitrary, which follows the independent, autonomous from research judgments, existence of the phenomenon. This impression is due to a truly free - or involuntary change in the scale of the artifact measurement. The mobility of the criteria for the study of the artifact, in turn, is explained by

88 Артефакт. Артефакт культурный. Культурология. XX век. Словарь. Сост. статей А. Красноглазов, А. Флиер. Спб.: Университетская книга, 1997. С. 44; 46.

${ }^{89}$ Там же. С. 44; 45; 46. 
differences in the limits of this phenomenon, which are opened in accordance with the method of its study.

One way or another, the phenomenon of artifact reflects a person's ability to create «artificial instruments» (L. Vygotsky's term), in order to transform both the external living environment and its own consciousness, that is, to control the experience of human interaction with the world and with himself. Therefore, it seems appropriate to find certain sign formations in artifacts - holistic sign conglomerates, which allow the sign structures to be considered as some artifacts the result of material and ideational intent of the relationship of man to the external and internal conditions of his existence. The special sign nature of the artifact corresponds to the need for a person to inhabit, to fill his living space with objects created by him and for his own purposes; this is, in fact, the creativity of cultural attributes.

However, such a sign attributivity of human experience is not so much external as psychologically motivated; it expresses the immanent features of human consciousness, the need for selfknowledge, reflection. Thus, signs - in their various forms and features - can be regarded as psychological artifacts, that is, as functional peculiarities of human consciousness, which are obtained in the course of the historical development of human mental apparatus and mastered by the personality during his individual formation. In other words, the secondary higher mental functions of the person, which are formed in the circle of processes of signification, what was revealed and appropriately named in the writings of L. Vygotsky ${ }^{90}$. are the generators of sign structures. Among these features of particular importance are the so-called «social emotions», including ethical (cognitive) and aesthetic «feelings». It would be more correctly to call the latter as integrating states of consciousness, equally addressed to rationally-logical and irrational subconscious structures, so, about the holistic realization of man in resonance with the world, as to the feeling of feelings and thoughts in their correlation with external objects of perception and assessment.

90 Виготський Л. Історія розвитку вищих психічних функцій. Л.С. Виготський. Собр. соч. в 6-ти томах. Т. 3. М.: Педагогіка, 1983. С. 5-328. 
Psychological artifact or artifact as a psychological phenomenon are those thoughts, feelings, sentiments-perceptions, judgmentsconcepts about them that are significant to the person, so, those that express the symbolic arrangement of the personal consciousness. They fix and make available for reproduction - transmission such features of the mental activity of the subject, as abilities, needs, attitudes, intentions, and "views", some other. From them grows the sense of art and consciousness in their interdependence; each of these «senses» has its own object, which correlates with the external and is free from it. The similarity of these «senses» arises, therefore, due to the fact that their external subject conditions create art and consciousness themselves, based on their own interests. This fact makes one think of a rule that was discovered in ancient times (by Protagoras), which states that man is the measure of all things...

Known semiotic categories, namely - sign, sign system, meaning, image, symbol, text - obtain the necessary conceptual completeness and adequacy to the facts of artistic creativity only when considering the psychological side of the phenomena indicated by them. Unfortunately, in most semiotic works, this aspect remains without special attention. And then the study of the sign nature, more broadly - the «artifactness» of the communication processes, in our opinion, can only stall - «rest» in the structural and material limitations of the sign or in the boundaries of the closest formal context. On the other hand, it would be equally wrong to confine ourselves to the psychological characteristics of artistic artifacts without leading them to determine the material properties of the artistic form as its sign conditions.

Turned away from concrete precedents, in particular, from genre and style compositional definiteness and stylistic designations of an artistic concept, discussion of the meaning of a composition (image, techniques, etc.) loses its evidence, moreover, deprives the object of study of another, after «artificiality», defining quality phenomenon of artifact - skill, that is, the skill of perfect form. Thus, the problem of the artifact, being connected with the problem of the sign and being projected into the field of art as a set of artistic forms, reveals a duality in accordance with the «dual» nature of the phenomena that interest us. It requires an approach both from the side of the structural and functional features of personal consciousness, and from the 
standpoint of autonomous subject matter of art. The interacting, two of these parties reveal the inverse movement of psychological and artistic sign systems, more precisely, allow to identify this movement as sign, that is not accidental, but purposeful and systematic, which implements the rules of ordering the meaningful activity of man.

The significance of consciousness opens to the human with too much power, since it remains an immanent phenomenon that relates only to itself. The importance of art, on the contrary, manifests itself at once, because it relies on the isolation, conditionality of the artistic form, which does not make it, however, easily accessible, because for the perception of an artifact as a sign formation requires a measure of the conditionality of the language of art. Psychological signs for a human are unconditional enough, so it is difficult to treat them as "not their own", brought, artificially made, programmed by the historical human community; artistic signs are too conditional, so special efforts are needed to accept them as «their own» as the basis of «natural» living communion. The sense of art is just as difficult to accept as its vital psychological material, as the semantic intentions of consciousness are difficult to grasp as a socialized form of objectsubjective communicative and subject-to-subjective «friendly» relations. However, it is these difficulties that are the main impetus for artistic reception and self-esteem. The reason for this paradoxical desire for difficulty can be seen in the need for a person to navigate in time and space - and not just navigate, but to possess them, to transform them from demiurgical principles, far exceeding the forces and capabilities of not only the personality, but the whole society, in the factors enhancing the value experience of both personal existence and the historical existence of culture.

The choice of material and its specification in each type of art is appropriate in terms of the possibilities of ordering, design of space and time. Not only the physical laws of the spatial and temporal factors of life and creativity are revealed, but also their conditional, metaphorical, symbolic, imagined - ideal - properties, that is, their special, human-invented, sign functions. The source material specific means - in painting can be considered the line and color that serve the organization of space (it is no coincidence that the two symbolic formations «left» in their poetry representatives of the new painting - formal abstractionist school - early XX century, 
abandoning all other additions of the painting form). A specific formative instrument of music is the «tonality» - sound, timbral and articulatory, rhythmic, aimed at solving the task of organizing a temporal process - to determine the processivity of time and the introduction of «distinctive signs» in this procedurality. It was no coincidence that Stravinsky believed that music exists solely for making order in time ${ }^{91}$. Agreeing with this idea, let us clarify that spatial factors are not alien to music (as alien temporal are not alien to painting), but they are subordinate, occurring after the ordering time conditions of the musical design, although in some cases they may be foregrounded, hide and remove time parameters of sounding.

Particularly noticeable are the spatial conditions of music in the general program - pragmatic performing - grounds of the genre, for which it is very important how and where the musical phenomenon "is placed". In the moments of genre genesis of music, especially in the everyday ritual sphere, these conditions become leading as contextual, in such a way introducing the external environment as a necessary sign environment - an active semantic background - into the meaningful plan of the musical phenomenon.

The material and structure-forming beginning of literature are logoforms, that is, not just verbal expressions with their grammatical and syntactic connections, but special couplings of verbal syntagms based not only on conceptual, but also on emotional-associative, generalized semantic relations - to relations of words to the processes of personal awareness, mediating the spatial and time principles of equipment of the universe. In this capacity, the word - logoform - is addressed to the psychological dependence of man on these principles and regulates above all the internal «space» of human consciousness, which allowed Vygotsky to see the main purpose of art in its ability to bring harmony and order to our souls ${ }^{92}$. Literature thus mediates both ways - spatial and temporal, describing them, making them distant objects of image, expression, figurative reproduction, symbolizing, transcending the possibilities of pictorial and musical

91 Задерацкий В. Музична форма. В 2-х вип. Вып.1: Підручник для спеціалізованих факультетів вищих музичних навчальних закладів. М.: Музика, 1995. C. 19.

92 Виготський Л. Психологія мистецтва. М.: Мистецтво, 1968. 
sign systems, leading them from the depths of personal realization to the sphere of verbalization - to the border of rational-logical knowledge. Hence the authority of the verbal factors for painting and musical creativity: verbal logoforms kind of «return» the semantics of other forms of art, passing it through its own sign system, in a clarified, refined form.

Creating its own special world, parallel to the real, invented from the point of view of object-material logic of life, intensely genuine for psychological realization of personality, art not only has specific chronotopic dimensions; it models such spatial and temporal relationships that are not in reality but are desirable and therefore assumed to be possible. In other words, art is always utopian and aimed at those ideal forms of chronotope, which in human life are attained only through the ideational way, that is, are understood with brain and in brain. The utopianism of art can be seen as the desire of human consciousness beyond its own borders - in the inaccessible and therefore especially attractive world, in the world of hidden secret connections between phenomena as their real causes.

The peculiar sign nature of the artifacts is due to the fact that they simultaneously represent two, equally important for human experience, spheres of being: explicit, object-material; implicit, which is perceived in indirect ways, though it is felt. Two leading sides of the artifact in art are related to this; the first of them reveals the specific material and means of this type of art, hence its external sign form; the other, addressed to the psychological significance of one or another means, will receive, ultimately, striving for the transfer of the unity, integrity of being consciousness as completely independent sphere of being human in the world, according to L. Vygotsky. In this regard, different languages of art should be understood as different languages of human consciousness. Modern psychology has already agreed that verbal language as a language of rational-logical cognition is not the only one for consciousness, nor is it the only logical one: simply other languages have other logic. However, before considering the issues related to the specific logical ways of different types of art, artistic forms, it is necessary to define the general - both external and internal - conditions of creation of «artistic objectivity». 
L. A. White points out that only in man as a species do we find understanding as a process of adaptation, done by symbolic means. Symbol, that is, a special artificial sign form, allows to develop a «metasensory mechanism of adaptation», «neuro-sensory-symbolic ability $^{93}$. In this way, the person goes beyond the immediate sensory impressions - the feelings, turns his organs of perception into tools of symbolization. This process, due to the historical evolution of the human psychics, underlies the artistic perception and assessment. Artistic consciousness, developing, is differentiating and specializing in connection, first of all, with the main channels of perception and forms of assessment, namely, visual, audio and conceptual; secondly, in connection with the relation in time and space - as general superpersonal or as individualized. Syncretism distinguishes not only the primary forms of art, but also the generic thematic content of art. Initial epic forms suggest a further separation of lyrical and dramatic principles, exemplified by the evolution of choral in its foundations of Greek tragedy art. If the epic represents the unity, community and continuity of ideas about time and space, their indivisibility and infinity, then the lyrics, as a lone "voice from the choir», separated, associated with the awareness of individuation, limitedness, finality, brevity of human life, in such a way contributing to the introduction of one of the basic antinomies of social existence - the antinomy «WE»- «I», which is transformed into opposition «I $\rangle-\langle$ They» in the case of confrontation of individual and social consciousness. So, from the stratification of the epic to its own epic and lyrical, there grow the prerequisites for drama - the conflict of man with the outside world, first of all, with his ego social subjects.

Differences of epic - lyrics - drama for all kinds of art are realized as differences in the scale of artistic form. Of course, these differences are motivated by different substantive volumes of epic, lyrical and dramatic forms. However, it is important to emphasize that length (duration) - size - forms, methods of establishing compositional boundaries are active and significant sign factors. The big epic, small lyric and medium dramatic forms, finding their ways in each type of art, provide specific conditions of action and

93 Уайт Л.А. Наука про культуру. Антологія досліджень культури. Т. 1. Iнтерпретації культури. Спб.: Університетська книга, 1997. С. 141-142. 
perception for each group of forms, including special relations with the context, their type of context as a «background» for the formation and functioning of the artistic object. For the epic form, the contextual beginning - the closest and necessary context - is human history in its ontological purpose, that is, the experience of existing states of being, the experience of being in the world, and the awareness of the expediency of that presence; the epic is always religious and canonical; in fact, we have the right to consider religious artistic forms or synthetic forms of «church action» to be «pure» epics, in the words of P. Florensky. About them, Florensky writes that " $\ldots$ being the purest phenomenon of ecclesiastical creativity, these forms prove to be the most cherished primordial forms of all mankind. ... It can be said that the more ontological a vision can be, the more general human is the form, which is to express it, just as the sacred words of the most secret are the simplest: father and son, birth, rotting and sprouting grain, bride and groom, bread and wine, the wind blew, the sun with its light, etc. The canonical form is the form of the greatest naturalness, something that you can not think of, while the deviations from the canonical forms are timid and artificial..."94.

The background material for the epic genre is life itself, interwoven into which, bordering on which the epic accumulates its own artistic value-meaning experience. The epic «figure» is thus directed toward the broadest life-giving foundations of art, while at the same time opposing them to a new understanding of the cultural and historical unity of society, forming that understanding. Psychological objectivity of an epic work is determined in connection with the reproduction of the general binary relations that underlie the aesthetic experience and are continuous, constant and unstoppable, evaluative states, such as creation - destruction, openness - seclusion, peace - focus, well-being (finding, happiness) - adversity (loss, misery); the equilibrium of the components of these paired factors conveys a state of harmony, and the formation of artistic canons is connected with the transfer of this integrating state.

${ }^{94}$ Флоренский П. Иконостас. Павел Флоренский. Христианство и культура. М.: Фолио, 2001. С. 561-562. 
Art, from its first epic genre «steps», is on the way of positively deconstructing the antinomies of being, above all, as the antinomies of human consciousness being. The purpose of the epic, through which the memory of it is stored in all derivative, later, genre forms, is associated with the discovery of aesthetic integrity and orderliness of the human experience, within which there are the prerequisites for more specific ethical and psychological reflexive relationships. The latter form a special subject area of dramatic and lyrical trends in the art. Continuity, generality of aesthetic states is counteracted by the discreteness of cognitive-ethical approaches, the specific and individual nature of personal self-esteem.

From the side of their psychological significance, the concept of good - evil, strength - weakness, confidence - fear, love - hatred (trust - jealousy, anxiety) and some others become leading. In contrast to the aesthetic antinomies that open to the epic consciousness, these antinomial pairs, implementing dramatic and lyrical settings, tend to exacerbate contradictions, to the indelible antinomial tension, to the disharmonious advantage of the conditionally negative side of antinomy. Both dramatic and lyrical are always fraught with tragedy complications and foresee the latter even when demonstrating their overcoming, because such overcoming is somehow revealed as temporary. A true and effective removal of the self-contradiction of antinomy is possible only when achieving a «psychological synthesis» of epic scale, that is, when engaging the perfect unity of life and knowledge of this perfection...

However, the dramatic and lyrical trends in art have their advantages, namely: firstly, they allow to enlarge, bring closer the individual and unique, unique in the creative, including psychological and creative experience of man; secondly, they reinforce the value of the artistic form, turn it into an «artifact», an initiative of culture. Only the lyrical (which inevitably becomes dramatic) author becomes absolutely «the first person» on whose behalf and by the will of whom the artistic form is built, and therefore he becomes the «background» material for such author - his ability to understand self-knowledge and assessment of his and another's psychological "walking into reality». The literal reduction of the lyrical form corresponds to the narrowing of the subject sphere of the author's interest - from the macrocosm of the unified life to the microcosm of 
personal consciousness, but such reduction - narrowing requires a new semantic depth of form, adding and transforming, that is, quantitative and qualitative changes in the content functions of a sign.

The lyrical form always gravitates to the symbolism that goes from the deep sign structures of personal consciousness, clearly demonstrating the psychological nature of artistic artifacts. Seeking to identify this law of lyrical form as starting for all artistic creativity (but with varying intensity), P. Florensky writes that «art is an embodied dream» because dreaming is «completely teleological or symbolicalı ${ }^{95}$.

Noteworthy is the fact that the researcher makes relations of time and space the criterion of dream symbolism, and respectively the artistic form, thereby returning us to these phenomena as the starting artifacts of culture: «... in the dream time runs, and accelerates towards the present, against the movement of time of alert consciousness. It is inverted through itself, and thus all its specific images are turned out with it. And that means we have moved into the realm of imaginary space. Then the same phenomenon that is perceived from here - from the realm of real space - as real, from there - from the realm of imaginary space - it seems imaginary...". Such a special «teleological time», which opens in the dream of the deep human consciousness, can be perceived as «living energy that forms reality», «as a creative form of life» ${ }^{96}$. Thus, it is worth answering the question about the psychological conditionality of artistic artifacts and the creative expediency of the sign, symbolic construction of art.

\subsection{Interdisciplinary tendencies of modern musicology and the noological conceptual sphere}

Becoming aware, that is, referring to the semantic content of music and its symbolic capabilities, musicology is forced to look for specific verbal forms. It should be emphasized that musicology

95 Флоренский П. Иконостас . Павел Флоренский. Христианство и культура. М.: Фолио, 2001. С. 530; 529.

96 Там же. С. 528. 
begins to look for a new language after the composer's creativity has fully mastered the idea of meta-music as a super-historical universal language. Does this reduce the innovative conceptual capabilities of science? It seems that no - and it is because of the appeal to the metalingual symbolological properties of musicological discourse.

The problem of the meta-language of musicology can be considered from two positions: from the standpoint of the logical foundations of musicological scientific activity and from the immanent logos of music.

Being the part of the circle of relevant common problems of culture, «meeting» in this circle other humanitarian disciplines, musicology manifests itself in a dialogical position, for which the interaction of «alien - own», «own - alien» is typical. It goes through different phases of dialogue: from subordination to the authority of related disciplines («alien») - through exploring their logical apparatus and subject choice - to self-legitimacy against them, to the transformation of others' initiatives into their own, exceeding the achievement of the discipline - the original addressee of the dialogue. In essence, this kind of dialogue, from his point of view, is considered by I. Kotlyarevsky when he characterizes the «extrovertedness» and «introvertedness» of musicological thought (we should notice, coming back to the previously nonspecific musicology, especially with regard to musicology, terminology). Yes, extrovertedness, in the opinion of the named author, can be manifested in two types centrifugal and centripetal. Centrifugal is based on borrowing alien experience and projecting it to the own cultural problems of musicology; centripetal means an increase in the excess of the own experience and the desire to give it to others. An introverted orientation is formed between the two types of extrovertedness; it is associated with the conversion of the first into the other. For the current state of musicology, the importance of introvertedness as an initiative of renewing the position of musicology in the context of humanitarian knowledge is growing, leading it to occupy the place of the first - authoritative - subject of interdisciplinary dialogue ${ }^{97}$.

97 Котляревський I. Музично-теоретична україністика. Украӥнське музикознавство. Науково-методичний збірник. Вип. 28. Музична украӥністика в контексті світової культури. К., 1998. С. 12. 
In connection with the subject that interests us, let us say that entering into the phase of «own - alien», the growth of «own» authority, the formation of «own» musicological textology at the present stage are important preconditions for the transformation of interdisciplinary links of musicology into its interdisciplinary innovation.

For the interdisciplinary experience of musicology, that is, at the stage of its «extraverted» development, the following areas of humanitarian knowledge and relevant subject areas of musicological thought were leading:

philosophy, aesthetics - music as a form of reflection of reality, place of music in the family of arts;

literary criticism - theory of genre, style and composition, theoretical and historical poetics, lingual communication;

semiotics - the nature of the sign (with the advantage of rational logic and syntactic approach);

psychology - psychophysiological bases of perception of music and musical abilities;

sociopsychology - stratification of the audience, the recipient as a subject of society.

Even if the selected interdisciplinary subject communities do not exhaust the full range of substantive correspondences of musicology and related sciences, they give the opportunity to notice their leading feature - the reliance on the objective results of creative human activity, which allows to establish a fairly clear boundary between artistic texts and life. But the content of the musical symbol remains a constant object of the methodological concerns of musicology, otherwise it is the spiritual purpose of the musical form, since in music, as Stravinsky noted, the spirit disappears with the form; therefore, it is revived with the form. Stravinsky said about the compositional principles of music: the more restrictions you impose on yourself, the more you free yourself from the fetters that hold your spirit...

For the interdisciplinary tendencies of modern musicology, confidence in the subjective factors of the creative process, the idea of music and culture as phenomena of a holistic psychological nature, interest in changed states of consciousness as self-evident «signs» of artifacts of other reality dimensions becomes evident. In particular, the subject of musical and musicological reflection is the 
phenomenon of silence - silence, as a sign of convergence to the last absolute sense, which is safer to be silent than to speak. It is with the help of this «silence», expressed not only in the power of sounding, but also in the unhurried deployment, that a feeling of the temporal moment fullness, «which must be exhausted by the end - as if gradually flowing into another moment» is determined. The music «simply runs out, disappears, fades, melts - even the silence begins to sound - from which it emerges and into which it returns..."

Silence, pauses, breaks, after-sounding become «heard» and music, and musicologists, become a new spiritual reality of the musical text after the experience of defining the sounding and the techniques that ensure its fullness reach their semantic boundary. It is a paradoxical feature not only of the musical, but also of the individual psychological dialogue with reality: today, in order to be heard, it is not enough to speak out loud - it is necessary to «speak» extremely quietly.

Starting from V. Rudnev's opinion about the antinomy of the text - reality (as one of the basic for the personal, so to say, «hypostatic», in the concepts of P. Florensky, consciousness), let us conclude: when the text is silenced as artificial reality, invented by man, the sounding of Reality can be heard - like a text created by God. So spirituality as the "endurance of spirit" in human time reaches its last higher "blessed" (M. Bakhtin) instance.

«Meeting» with the sense becomes possible thanks to three fundamental (can be said, genitive) noological indicators of culture, which are manifested by its basic universals, meta-historical symbols - Memory, Love and Play. The constant need for their realization is supported by the constant dissatisfaction with this need, since «from the side of sense only infinity of assessment and absolute anxiety are possible» ${ }^{99}$.

98 Герасимова-Персидська Н. Нове в музичному хронотопі кінця тисячоліття. Украӥнське музикознавство. Науково-методичний збірник. Вип. 28. Музична україністика в контексті світової культури. К., 1998. С. 32.

99 Бахтин М. Автор и герой в эстетической деятельности. Эстетика словесного творчества. 2-ое изд. Сост. С. Бочаров; прим. С. Бочарова и С. Аверинцева. М.: Искусство, 1986. С. 37. 
The concepts of memory, play and love become the leading, especially responsible - noetic categories in the works of $\mathrm{M}$. Bakhtin, S. Averintsev, L. Vygotsky, Y. Lotman, E. Fromm, J. Huizinga and some other authors, are «breaking through» in such quality in musicological conception (E. Tarasti ${ }^{100}$ ). However, their theoretical (aesthetic and cultural, psychological, art) approbation becomes possible because they are presented with creative, first of all, artistic realities of culture. They are manifested in the context of the semantic dominants of culture as the intersection of sense and personal value life orientations, as a universal noetic way of self-knowledge, which also implies the social and moral responsibilities of the «semantic person». W. Frankl calls conscience «the basic semantic organ of man»; therefore, the way to sense is being corrected, controlled by ethical attitudes. This explains the activity of moral representations in ideational structures of sense, the interconnection of aesthetic and ethical attitudes (indicated, in particular, by Bakhtin).

Noetic orientation of semantic values determines the "great» symbolics of culture. Ways of crystallization of this symbolics (as ways of mastering the sense), including specific musical ways, can be represented as memorial-mnemonic, creative-play (playing), familial"love»; they are consistent with the levels of poetics (semantic signifiers) in music. Thus, the first tendency is related to the strengthening of the genre origin authority as the main «memory keeper», the most direct expression of the «memory» of music due to the dependence of the genre on social-normative mechanisms. Another (play) tendency is reflected in the autonomy of the structural and compositional laws of music, the cognitive tasks of musical poetics, and the technology of musical form, hence in the formation of specific means of musical dramaturgy. The third - the «familial» («appropriating») dimension of music - reveals the iconic properties of style as a predominantly authorial phenomenon in the full extent of its intonation possibilities. The first way is the way of «great form» (opera, oratorical, symphonic), aimed at a broad genre and style synthesis and symbolics of «catholicity», which embodies the call for spiritual unity around a significant community (religious in the broad

${ }^{100}$ Tarasti E. Music as sign and process. Analytica. Stakholen, 1985. P. 97-115. 
sense of the word) idea. The second peculiarly attracts typified and heuristic compositional techniques («canon» and «re-accentuation» in Bakhtin's terminology, which, produced by the protective eliminatory properties of music as genre and style memory, realize themselves as structural receptions «in the territory» of compositional plays").

Play compositional path contributes to the development of programmatic factors of musical creativity, including a special type of paradoxical symbolic programmability; so, it fundamentally changes the nature of words and music synthesis, synthetic compositional forms.

The third - style - eat opens the special object of the lyric in music: its orientation to experience as the main «hero» of music and instrument of suggestion, persuasiveness. It is, however, a special experience - the ability of the whole psychological resonance of a person with the world, when «the whole world» and «the whole person» meet, when «the world and the personality are combined... in a single focus...; the objective world and the world of the human personality do not oppose... each other, because the other contains all things» ${ }^{101}$. In this experience there is the phenomenon of musical spirituality, which, however, assumes different semantic positions and requires special qualities of musical semiology.

These efforts determine the methodological search for musicology; at the same time, they discover a methodological paradox: musicologists have to take on the functions of broad-based humanitarians, first and foremost, cultural scientists, because otherwise they will not be able to be musicologists - the kind they expect from themselves.

The semantic approach in musicology reveals its paradox in connection with the necessity of extremely mediated, extremely «far» movement to the directly perceived, which is perceived (somehow) by the semantic reality of music. In other words, to avoid simplistic figurative values, too straight musicological definitions, it is necessary to move away from the compositional boundaries of a musical composition - to the noetic poetics of culture as a whole -

101 Бобровский В. О драматургии скрябиновских сочинений. В. Бобровский. Избранные статьи и исследования. М.: Музыка, 1990. С. 148-158. 
with a subsequent return to semantic structures of music, rather of not ascertaining, but predictive character.

Musical sense (like any other) exists only in the form that bears it (in this respect music can be called the «supporting structure» of meanings), but is understood beyond its boundaries, including beyond the direct listening or analytical musicological examination. As a coherent formation, the meaning is not divided into musical and «non-musical». That is why musicologists have to search for what is deeper than sense, though it seems almost impossible... They have to search for universal grounds for unique semantic decisions, essentially eternal in random forms, in order to justify semantic evaluations of music. "In everything that is written by man, there is always something accidental,» asserted J. L. Borges. What is «deeper than meaning», manifests itself as a noetic (noological) universality of culture - a higher semantic essence of human relations, which is defined by the symbolic content of culture and the related nature of the artistic method, and much more broadly, and more precisely, from positions of traditional aesthetics.

The history of semantics in music can be understood and read as a history of relations between the experience of musical creativity and the experience of sense-making in general; it can be read as a kind of palimpsest, in which no semantic record is scraped to the end and through one designated sense something Wales inevitably stands out. Such mutual illumination of meanings is the only legitimate basis of semantic concepts of music.

To determine the conceptual basis of the noological concept of music, the following definitions emerge.

Noetic is a special value-semantic dimension of culture, which is formed by man himself and is the result of creative activity of human consciousness; it cannot be represented as just one, even if very responsible, "semantic paradigm"; it is a system of relations united by their common addressee (Over-addressee), the noosphere. This sphere is accessible only to the indirect - «side» - vision, just as understanding becomes available only in the «reflected» form - by clarifying and being pinned to knowledge. The latter inevitably simplifies, limits, but «calls» what we seek to understand, defines the boundaries of our comprehension - incomprehension and allows us to interpret the phenomena of the world from the standpoint of these 
boundaries. Noetic also creates a special dimension of human «psychological reality», becomes a fundamental condition of phenomenological theory, goes to the concepts of noem, noes, noesis of consciousness, etc.

The initial concept of the noetic is linked to three sources: philosophical and religious doctrines of the universe, natural and scientific theories of the evolution of life on Earth and psychological conceptions of man. It is derived from the concepts of «Noosa» (Aristotle and the noological theory of catharsis in the interpretation of the teachings of Aristotle by A. Losev), «noogenesis» (T. de Chardin), «noosphere» (V. Vernadsky), «noetic dimension of consciousness» (V. Frankl). Each of these concepts in the context of an appropriate approach is conditioned by the decision of questions about the origin, organization (order) and expediency of a reasonable human life (Greek. «Noos» - «mind»), claims to denote higher (divine) consciousness, mind as a tool of awareness of everything, what happens to a person in the world, all creative conscious activity of a person. Thus, the noetic appeals to the human experience in its universal (common and unified) boundaries and, as a concept, can be classified as a «category of boundary fundamentals» (O. Kyrylyuk's term $^{102}$ ) of culture.

The noetic in culture exists as a problem of higher, «boundary» («last») semantic boundaries, therefore, and as a problem of the hierarchy of meanings, their correlation with meanings, choice of «semantic instance», the Third in dialogue (Over-addressee), in such a quality defining the type, form of dialogue. From this point of view, different kinds of artistic creativity have different possibilities, dictated by the nature of this or that kind of art.

The noetic dimensions of musical culture can be represented as memorial-mnemonic (as two poles of memory: protection, preservation, confirmation of authority - memories, updating of values, transformation into a new context); conditionally-playing (formally-creative instrumental relation «on the background» of memorial-mnemonic: it is possible to play also with memory); familial - «love» (approaching and development, immediate

102 Кирилюк А. Универсалии культуры и семиотика дискурса. Миф. Одесса: Изд. Дом «Рось», 1996. 
«meeting», opening the possibility of sympathy); they are agreed with the levels of poetics (semantic signifiers) in music.

The concepts of genre, style and composition, as already special musicological, reveal a new content, being included in the categorical sequence that was formed in the process of discussing the phenomenon of sense in culture and music. There are a kind of «stairs» of categories: culture - understanding - sense - symbol dialogue - word - semantics - musical symbolics - semantic representation - text - aesthetic - poetics (form) - genre composition - style. The last three concepts can be continued in such triads as «theme» - plot - image, «intonational stock of sounds and ideas» (B. Asafiev), «memory» - «learning» - «appropriation». In the last triad, it is easy to recognize the basic noetic tendencies (memorial, play, familial), but they are already connected with the processes of action and perception of music, from the memory of culture to the sphere of memory as an individual psychological, personal phenomenon.

Noetic antinomies are generated by the complex nature of higher semantic phenomena. Thus, the basic antinomies of the phenomenon of memory, in many respects decisive for the associated artistic symbolics, are preservation - oblivion; increase (of volume) elimination; sacralization - profanation (familiarity); «remote» close; long-term - fleeting; old - new; canonization - reaccentuation.

The antinomic structure of the phenomenon of love is manifested as the interdependence of life - death; gifts - losses; victims conquest; praise - weeping, joy - pain; high - low; integrity fragmentary (divine - human).

The antinomies of the play are extremely branched, because it corresponds to the immediate actualization (realization in action form) of the need for a dialogue «I $»-\langle$ Other», «mine» - «alien», is the creation and development of conventions, «artificiality», monopolizes the principles of repetition and the distinctions that are the cornerstones of human activity, including consciousness (and musical form). These antinomies include the order - freedom; conditionality - «inclusion», immersion; removal - acceptance; skill - naivety (adulthood - childhood); pragmatism - selflessness; efficiency - illusory; creativity - non-productivity, completeness - 
openness; serious - laughable; imitation - invention (originality); incarnation - reincarnation and some other.

From the side of the textually attested signs of sense, memory is associated with the identity, repetition, reproduction, borrowing, broadcasting, restoration, «remake», quotation (stylization, allusion), so, the development of temporal parameters of sense; the play is expressed in fulfillment, adherence to conditions, dressing transformation, competition (achievement), correctness (knowledge of rules), ordering (creation of order); love - in attraction, interest, personal motivation, integrity of relations, emotional state of what is happening, co-experience, in «non-alibi in being», to use M. Bakhtin's words, in the human authorship of life - exclusively in human form of involvement, co-existence.

Highlighting from the listed noetic phenomena the phenomenon and the concept of memory, we note that it itself has a complex systematic structure, corresponding to the complex arrangement of human and human life, human culture. Therefore, it obtains a separate epistemological position in the circle of musicological categories.

We should note that epistemology is one of the most capacious, possessing the ability of methodological integration, areas of humanitarian theory of cognition, for which in recent years the priority tendency has been the interaction of philosophical and artbased approaches, therefore, the convergence of conceptual and logical and aesthetic analysis. Since the epistemological apparatus of musicology is still being formed, and because of its breadth, it does not presuppose final definitions of methodical boundaries, it is possible to find at the present stage two major boundaries in the field of phenomenological representations (with their inevitable profundity in psychological problems) and noological and ecological ideas about existential specifics of a human and artifactual environment, created by him.

Conditional opposing of phenomenological and noological approaches, as an internal intentional and averted formal-external symbolic, is removed when studying those phenomena and categories that, firstly, obtain the value of universal, and secondly determine the a priori foundations of human culture and become paradigmatic for art creativity; thirdly, determine the specific value-semantic logic of the human consciousness development. 
The need to clarify the phenomenon of memory from the standpoint of musicology reveals the need to combine cultural, textual and psychological approaches to this phenomenon, that is, actualize the internal methodological and disciplinary branch of modern music science, the systematic nature of musicological research. The main aesthetic, semantic and cathartic functions of memory are determined in the core of system-conceptual consideration, caused by the intersection of the above-mentioned approaches. So, the broad purpose of this phenomenon in the life and creative activity of a person is revealed, while at the same time three main levels of consideration of memory as the main "hero" of the musical world of culture are identified.

M. Bakhtin associates a semantic mechanism of culture with memory, believing that memory is a value-driven past, an industry of primary sources - «sacred texts», authorities that can only be joined, without changing anything in them. Such memory becomes a commemorative beginning of a culture focused on affirmation strengthening, perpetuating... ${ }^{103}$. However, memory is also a mnemonic beginning, a remembrance of the past in the present, the transfer of the past experience into new conditions, its actualization necessary for continuation - transferring the value experience of culture. Such a need gives rise to a «familiarity» - a living, today's touch on values, relating to them without a distance, removing the ban on communicating with them, overcoming estranging selfesteem, appropriation, experiencing closeness - as the own living in sense $^{104}$

At the heart of memory movement from the memorial pole to the familial-mnemonic there is the combined experience of personal consciousnesses development (and the development of personal consciousness - self-awareness - in man), which relies on «reaccentuation» in its broad meaning, on the restructuring of inherited knowledge. It is this approach to memory activity in the concrete application of it to the process of musical perception that E. Tarasti

103 Бахтин М. Эпос и роман. М.М. Бахтин. Bопросы литературы $u$ эстетики. Исследования разных лет. М.: Художественная литература, 1975. С. $458 ; 462 ; 464$.

104 Там же. С. $451 ; 457 ; 481$. 
proposes. Without exaggeration, his work on memory is still the most consistent in the psychosemiotic direction he develops. The phenomenon of restructuring Tarasti reveals in connection with the psychological epiphenomena of «expectation» and «tension», which correspond to the «density» - the semantic filling, the weight of the musical composition ${ }^{105}$. It is easy to see that the «expectations» and its justification are interrelated with the phenomenon of the tradition nature of musical thinking (creativity) and perception.

Historical time is a constant basis for human activity, regardless of its representation degree. The subject of dialogue always turns out to be the subject of history - just at its different stages. Even a personal story - a biography - is not going away from social life, but motivating, heading for the latter. Therefore, the responsibility of artistic memory is related to the search for historical, that is, necessary for the moment of culture formation, authorities.

The reference to authority, the involvement of authoritative judgment on its part, is the citation - an important argument of artistic dialogue as a mechanism for the realization and development of cultural memory - in its real and conditional forms. In artistic creativity such a searched authority is tradition, and not only its own autonomous tradition of this type of art, but also the tradition of culture as a whole. It is tradition as the «embodied memory of culture» that becomes the regulator of the relationship between «sense» and «text», therefore, between «aesthetics» and «poetics» in artistic creation, but as a special «semantic memory».

Musical language and play deserve special attention and are related in their cognitive nature, always relevant artistic and psychological processes, so, dynamic and historically changeable phenomena.

Musical language is a system of signs and their meanings existing (actualized) in a sound form that implies a written fixed equivalent; it has no direct prototypes outside of music - in the extra-artistic sphere. The idea that music copies only itself and has common nature with the myth, because it is a value structure that is self-generated, develops in the works of Ortega-I-Gasset. The musical language is

105 Тарасти Э. Музыка как знак и как процесс. Ното musicus. Aльманах музыкальной психологии. М.: 1999. С. 61-78. 
symbolic in nature - under conditions of formation, that is, connected with indirect ways of semantic concretization and this complexity enhances non-objectivity, non-factuality, freedom from the external reality of musical meanings, their «non-imaginability» and «nondescriptiveness» - that is, extra-obviousness and over-conceptuality. Hence the peculiarities of associative perception of music, which, on the one hand, relies on intimate and psychological conditions - on the experience in connection with the leading emotionally-expressive values of musical sounding, on the other hand - restores temporal conditions - both historical and compositional, listener's memory as an aesthetic, that is, as a memory of aesthetically significant temporal relationships in music that were somehow reflected in the compositional form.

Musical symbols indicate the modality of the experience as a whole, «grasp» the aesthetic orientation of the experience, and allow the musical sounding to become a special «sign» of the state of human consciousness. Thus, music acquires a special objectivity - it indicates the holistic nature of the experience, hence - the special experiences, adequate to the sense integrity; turned to subjectivepsychological reality, it is at once «understandable» and clarifies understood; being directly procedural, because it expresses the time and fullness of the experience flow, it creates a special emotional completeness of temporal moments of the psychological process and through it sends to the world of objective processes, mediating and «appropriating» their content.

Time and experience become the main «heroes» of music, and if time - duration, temporal unfolding, fixedness of the musical composition - allows you to notice the experience (determine its mode and give it a «name»), then the experience allows you to see time as a movement, becoming its through-living and «coloring» the neutral time flow in «emotionally volitional, value-tense» tones (let us remember the favorite Bakhtin's words). Without such help without «dressing» the temporal process into «clothing» of compassion - time is perceived as motionless (as «standing»), therefore, it goes unnoticed and unformed in the mind.

Symbolic intentions of music are manifested by its stylistic autonomy - «self-legitimacy» - and indicate the possibility of entering the «life world of culture» in the context of musical 
composition (music as a form), the subordination of life logic to the artistic sense (auditory perception - feeling) of the world. The possibility of forming «own» musical symbolics depends on the semantic determination of sound, «meaningful» material of music as the possibilities of musical style activity depend on its genre independence. Musical «signs» are the subjective and structural ingredients of music - twofold, "two-faced": on the one hand, they are directed to genre definitions, on the other - to the style interpretation of known, real and possible genre content. Style signs, emancipated by the lingual activity of music, form a special branch of musical symbolics. Representing a set of stylistic techniques, a style sign is the most specific, «pure» form of «musicality», so, «self-talk» of music. Nothing in music achieves autonomy until it reaches style expression, hence stylistic self-talk, recognition in style. But at the same time, no matter how free style is, it always «remembers» the genre: it is its «secret» memory, «secret» name, hidden connection (no wonder M. Bakhtin claimed that where the style is, there is the genre). Thus, genre relations are involved in the orbit of musical symbolics, but in a deeply mediated form - as a special memory of the conditions, the causes of the birth of this form of music and its accompanying type of musical expression, «sound-idea".

Symbol in music as a compositional structure obeys two trends. On the one hand, it strives for sign relief, subjective brightness, for accessible, «easy» to perceive emblematic, for laconicism, concise presentation, emphasizing «materiality», material «weight» and convincing acceptance of presentation. On the other hand, it is characterized by semantic duration, length, branching, and orientation towards the increasing historical coverage of the semantic functions of this composite reception, up to its universal significance as a carrier of spiritual value, «justified spiritual sense». In this way, the definition of the symbol proposed by S. Averintsev is confirmed by the music ${ }^{106}$.

The multidimensionality of scientific explanation of the play, including its expansive interpretation, which seems sometimes unjustified, is manifested in the cultural direction represented by the

106 Аверинцев С. Символ. С.С. Аверінщев. Софія-Логос. Словник. К.: Дух і Літера, 1999. С. 154-159. 
works of J. Huizinga, and partly by G. Gadamer. Thus, Huizinga believes that the play is older than culture and is «occupation extraordinaire», has a cosmic origin ${ }^{107}$, so it finds a source of culture in the playing activity of man, that is, offers the concept of the play genesis of culture. At the same time, Huizinga defines the aesthetic elements of the play (transforming it into a wonderful phenomenon), because the play is superfluous and self-interested, and for that it must do two things - bring to the order and be beautiful. These aesthetic elements, called by Huizinga, namely, tension, balance, alternation, contrast, variance, tie and outcome, resolution, as well as its two key features - rhythm and harmony (beauty) - can be taken as a characteristic of artistic, and also musical form. They can be applied to the latter as a play, because they indicate the first rule of the play: the creation of conventions, conditional artificial order, which replaces the real and even competes with it. This author calls the second rule of the play: its ability to release, «reincarnate» and thus open up new resources of the vital forces.

In this regard, the positive cultural conception of the play is opposed to the traditional psychological (empirical and psychotherapeutic), which proceeds from social programmability, limited personal consciousness and the need for protection in transactional behavior. Here the play is considered as role manifestations of personality, individual planning of human behavior (in everyday context), and its results include even such negative phenomena as alcoholism, suicide, drug addiction. Winning such a play is a temporary socio-psychological domination that allows you to maintain positive self-esteem artificially ${ }^{108}$. Such a play is far from freedom; on the contrary, it demonstrates the dependence of human consciousness on social rules and orders, in many cases narrowing creative life possibilities, it cannot be considered productive for man in the full sense of the word.

However, one of the last definitions of the play indicates that «the play is a kind of unproductive activity the motive of which lies not in

107 Хейзинга Й. Homo ludens В тени завтрашнего дня: Пер с нидерланд. М., Прогресс - Академия, 1992. С. 9; 13.

108 Херсонский Б. Глубинная психология. Справочное издание. Одесса: Астропринт, 1998. С. 58; 41-42. 
the results but in the process» ${ }^{109}$; it is hard to agree with that. Recognizing the purposeful autonomy of the gameplay (play unselfishness, expediency without purpose, which after the Kantian theory of the aesthetic became a common place in art studies), one must also recognize its productivity - performance as a person attaining a higher («top», in L. Vygotsky’s terminology) degree (and the stage) of self-realization (self-actualization, in A. Maslow's terminology), that is, the knowledge and liberation of one's essence, of a real life purpose, of joining the higher semantic order. Only such an approach to the play can be called noetic and justifiably psychological. Play as a noetic phenomenon leads to the rejection of all temporary winnings for the sake of the main one - the winnings of oneself as a creative subject; such a play is «taught» by art.

The artistic form realizes the basic antinomy of the play: conditional - unconditional (conventional - non-conventional, artificial, illusory - «true», real). Artistic influence - perception is equally required by knowledge and adherence to conventions (rules and boundaries of composition), ability to recognize it - as well as the ability to be directly involved in the artistic process, to become its participant, to absorb the idea of experience and to «bring» it into boundless (free) meaning. Hence there are the purpose of the play and the various play functions of composition (form of work) in music.

The importance of playing factors in music is reinforced by its performing side: a musical play is literally like performing on certain instruments (however, for a vocalist, voice is an instrument given by nature). The motor-dynamic sphere, the directly technological sphere of music is the first conductor of the artistic purpose of the artistic form and the prerequisite of indirect imaginative play, psychological dynamics, including the conditioned dramatization of the musical concept, its likening to theatrical action. Play - composition motority form a related set of concepts that helps to determine the ways of becoming «pure» instrumental music.

The play of perception of musical material plays a leading methodical role in neoclassicism as a play with style models. However, musicologists approach the named «play» somewhat

109 Гуревич П. Игра. Культурология. ХХ век. Словарь. СПб.: Университетская книга, 1997. С. 133. 
unilaterally. They are more interested in the question of why and how composers "play" neoclassics, that is, what is the nature of the «style model» and under what new compositional conditions it manifests itself as it changes in comparison with the original source. In our opinion, the question should be posed a little differently, namely: what are the reasons and purpose of the neoclassical play, that is why and what for it occurs? In this regard, it should be noted that the concept of «style model» (as the subject of «play») is not entirely correct; it is impossible to «play» with style directly: aesthetic representations are reproduced - and then we are dealing with the separation of the semantic plan of the composer's poetics, or the stylistic components of the musical language that served as the subject of the «mnemonic play» - and then before us the selfsufficiency of the structural plan of the composition. The latter is perceived most directly as a compositional-opus «surface» of musical design, becoming the beginning of a «big play» with sense, but not yet promising on the part of stylistic conclusions from this play, while the first is the author's semantics with the aesthetic vision of reality contained in it is generalized and performed outside of a particular composition.

The given justification for the neoclassical method is confirmed by the following. First of all, the substantive basis (the choice of material as «co-speaker») in this type of musical dialogue is gradually expanding, which is connected with changes in the musicological terminology addressed to it. This play is more and more often called neoclassical, which should be an indication of the use of structural and semantic realities not only music of the period of European classicism, but of any historical period - from the most distant to the closest; in the latter case, the historical distance between the primary source and the initiating dialogue of the creative personality, the actual author, is artificially conceived (by means of art), re-created, as, for example, in the inter-authorial dialogue of B. Tyshchenko and D. Shostakovich. However, the last form of neoclassical dialogue, which forms (another term indicating the neo-classical musicologists' interpretation) the classifying tendency of musical creativity ${ }^{110}$, is not

\footnotetext{
${ }^{110}$ Варунц В. Музыкальный неоклассицизм. М.: Музыка, 1988. С. 7.
} 
always perceived as such, since for the method of neoclassicism it is most important to understand the irreducibility of historical distinction, that is, the loss of the great musical personalities of the past forever. This paradoxically restores the interrupted «connecting thread» of times, and arises not from a dialogue with another creative personality in its real past time (the literal return in time is impossible), but dialogue with music both general and any time subservient to the text, with its constant present.

Therefore, the motivating cause and main purpose of the neoclassicist (neoclassical, classifying) play is «dialogue of cultures» - the highest form of meaningful - noetic - dialogue, the highest available to human consciousness and cultural creativity. It can give the impression of an interstyle, inter-authorial, but it occurs in an inter-stylistic way, by semantic deepening of the textological structures of music, thus serves to increase the sense in music by increasing these structures, serves to the self-increase of the musical «logos».

The stylistic carriers of style meanings available in the analysis can be defined as style signs. The «dialogue of cultures» proclaimed by neoclassicism is made possible by the separation of the stylistic sphere of music as self-sign, as the general material of music and its generalized text. The peculiarity of the neoclassical attitude to this significance of music is conditioned by the antinomy of «former»«non-former» (recall, this is one of the leading memory antinomies in L. Vygotsky's theory). On the one hand, as a set of autonomouslogical forms of music, the musical text is «former»; what has already happened claims to be immutable, its own systematic ordering, and is quite accessible for direct reproduction - development. But it is this position, called the «new objectivity», that transforms «Ich - Musik» into "Es - Musik"111. On the other hand, as a bearer of lively style intonation, personal senses, its («former» text) achievement in terms of «time difference» of musical creativity becomes a literal utopia, because in this capacity the musical text is the place from where we are gone and where will never be again («absolutely ready» and «closed» past, according to M. Bakhtin). Composers-neoclassicals do

${ }^{111}$ Варунц В. Музыкальный неоклассицизм. М.: Музыка, 1988. С. 7. 
not assume that their present style position can be equated with the «former», because the phenomenon of «style memory» mediated by their creativity is revealed as the memory of the non-former, based on a special imaginative, that is, arising by means of imaginative imagination - imaginative play of imagination, semantics (a term borrowed from the theory of memory by L. Vygotsky). Thus, there are prerequisites for giving known structural formulas (stylistic signs) new meanings, which, as already stated, is preceded by the emancipation of the sign from meaning; but so does the own free sign neoclassical sphere, which, as a «memory of the non-former», does not yet have sufficient semantic recognition and is represented by «constructivism», logical play, «pointless» structuring, even to negative evaluations, as «wrong objectivity».

Indeed, from this point of view neoclassicism appears to be a play of «empty forms», a kind of simulacra, but in this way it justifies the latter, taking them out of the sphere of negative phenomena of culture, into which the phenomena of J. Baudrillard's simulacrum and postmodern aesthetics have been sent.

In the context of neoclassicism, «empty form», «pseudo-thing» is a sign of the composer's creativity advance of traditional musical consciousness, a kind of «memory of the future». (Today we are already convinced of how semantically «filling» formal compositional discoveries, for example, of I. Stravinsky, newViennese, some others ...). Imaginative way of musical semantics allows the composer's opus to take the main, starting position in the dialogue with the textual conditions of music, the consequence is that the composer's structural reception becomes a "graceful symbol»" ${ }^{112}$ of the genre and style content of music, that is, not only symbolic intentions of the content give rise to musical values, but also compositional logic. Music is able to generate new meanings of sense as symbolic.

A convincing example of the neo-classicist attitude to the text is P. Hindemith's work, above all, his dual experience of inter-style, that is, intra-stylistic, intra-textual dialogue - the cycle «Ludus tohalis» and «Symphonic Metamorphoses of K.-Weber's Themes»

112 Холопова В., Рестаньо Э. София Губайдулина: Монографическое исследование. Интервью с Губайдулиной. М.: Композитор, 1996. С. 191. 
(1942 and 1943, created in close proximity, suggesting a certain methodical unity). These works of Hindemith represent the two sides of his neoclassical method. On the one hand, in the Neo-Bahian cycle the composer seeks to reproduce the general idea of «Bahianism», which is for him a rather broad sphere of polyphonic music, that is, to find its semantic denominator. It becomes quite the author's (Hindemith) idea of «world harmony». Confirmation of his aesthetic position Hindemith finds in the work of Bach and the general polyphonic context of this work, expressing its correspondence with the semantics of Bahianism, that is, the «answer» to the semantic issues indicated by this semantics, by means of structural differences in the overall composition, in thematic, in part and so on) of its cycle from the summarized (understood and known) logic of Baha'i works. Thus, the composer seeks to «express» what defined the semantics of Bahchian music, but «in its own words,» the original compositional way.

On the other hand, in the neo-Weber cycle, Hindemith relies on direct quoting of Weber tunes, but by means of this literal reproduction of Weberian thematicism, denotes a different, opposite semantic setting, that is, «in the same words» trying to «say» a fundamentally different meaning. Ultimately, this way also leads to a change in the compositional conditions from the original (to «metamorphoses»), but the starting point is still the differences in the semantic presumption of the data of the two composers and poets in their «external» musical-thematic similarity.

From the side of the musical-creative process, a factor of the play's beginning development is a special relationship between retrospection and heuristics, which allowed to rise to a new level of sense formation of the method of style reflection - both as a dialogue with tradition and as a prognostic composer's self-dialogue. In general, the problem of noo-style dialogue seems to be one of the most promising for the methodical enrichment, restoration of musicology, and from its semantic side, that is, due to the phenomenon of musical semantics.

Musical semantics is, first of all, a psychologically conditioned phenomenon, connected with the norms of perception and with the modes of action, influence of music. The discovery of musical semantics is the result of semantic representation, which is 
manifested in the abstraction of musical meanings from sounding, creating in this way a new psychological reality for the signmeaningful functions of music. Semantic representation is associated with the translation of musical meanings into a new system of measurement, with verbal and conceptual explanation and clarification of sounding. The latter gives an opportunity to enhance musical meanings and their programming, because it is the conceptual level of consciousness that enables the transfer of past experience to situations, which have not met before, that is, the ability to predict (including musicology).

The evolution of musical semantics as an «accumulation» of the symbolic possibilities of music can be represented in the form of a basic dialogue of genre and style, in which the desired third, «ideal Over-addressee», becomes a composition. This kind of dialogue correlates with the basic noetic dialogue of memory - love - play, which express the fundamental dependence of personal consciousness on the «memory of culture», at the same time, its freedom - just as dialogic and only in the dialogue achieved. The peculiarity of such dialogue is its internal structural mobility, caused by differences in quality types of dialogue. The reason for such differences can be seen in the change of the ideal Over-addressee - as in the change of epistemes. In the field of musical semantics, the mobility of dialogic relations is connected with the different orientation of the formation towards confirmation and consolidation of the authority of the genre, towards the play will of the composition, to the sphere of free styling - the author's stylistic idea. Each of the above-mentioned beginnings of musical poetics can occupy the position of «perfect Over-addressee»; their consistent change and the nature of the new dialogic relationships that emerge at the same time testify to the evolution of the historical experience of music. Data initiating the beginnings of music can also be represented as its semantic dominant - in the «great» dialogue of music with the surrounding reality.

Musical semantics is an extremely broad phenomenon in which all forms and levels of a noetic approach converge, which allows one to judge music as a semantic context of cultural consciousness, to explain the nature of musical self-dialogue. Thus, semantic analysis of music should cover all directions of formation of musical 
«Noosa»- aesthetic (proper anthropological), genre and style compositional, stylistic (directly textual); their separation is due to the superiority of any of them in the studied musical phenomenon, formalizing the course of analysis, but at any time of music being, they are present as a single unit, indicating the noological integrity of sense in music.

\subsection{Tragic cognition and catharsis: from aestheti and psychological analysis to musical theory}

Tragic cognition is an extreme case of human self-dialogue and human dialogue with the world. It is no coincidence that L. Vygotsky relies most on determining his nature, revealing the phenomenon of catharsis. In this position (as a tragic attitude and experience), this phenomenon disturbs the researcher insofar as the tragic (tragedy) in art is a marginal and strange case of artistic purification associated with the positive uplift of feelings. The viewer, the listener feels the highest aesthetic pleasure, the joy of the phenomenon that in his everyday world is the most awful for him and makes him flee. A. Malro pointed out - as at «weirdness» of tragedy perception - that after watching the tragedy (referring to the Oedipus tragedy with its healing final scenes), we try not to roll our eyes as Oedipus did, but again to go to the theater... What is an unbearable need for tragedy? The answer to this question is closely related to the definition of the role and originality of artistic (aesthetic) emotions and their inherent affective contradiction. At least, this is how it appears in the concept of L. Vygotsky.

We have to give a kind of translation of Vygotsky's thoughts, approaching the actual tasks of today, the language of psychology of arts, to conclude some of his thoughts in the interpretations, because, given the complexity of the problem of catharsis, the researcher did not claim its full elucidation. We should recall that finishing his research; he noted that the solution to this problem was left by him outside this book. The problem of A. Leontiev's catharsis was not solved - and it is understood why: for him, not only was it not solvable, but also a problem that could not be posed, the problem of the unconscious seemed. 
In developing the problem of tragedy, L. Vygotsky meant that in our daily lives, the experiences we have, the feelings that penetrate our consciousness, are not sufficiently clear, defined; the same moments when they come to the fore are remembered as exceptional, not typical of everyday consciousness. When we experience something so intense that we notice the experience itself, it means either a very great joy or a significant distress, that is, something extraordinary.

If we recall Vygotsky's words about the collision of the unrealized subconscious desire with the conscious part of our behavior as an urge for creative self-realization, it becomes clear that under artistic experience with his contradictory nature he understood the particular opposite of the directions of emotions in the recipient's consciousness. On the basis of this opposition, a kind of «dialogue» of consciousness and the unconscious is formed, in which each participant «draws» on its territory, on its own levels, which causes «affective contradiction». This contradiction assumes a cathartic nature in case if the movement initiated by both spheres of consciousness ends with a «sublime deepening» of consciousness, so, transfers the sense of the unconscious into the language of the conscious, and enriches the logic of awareness with the lingual capabilities of the unconscious. The interaction of material and form, as the basis of artistic emotion, is carried out in such a way as a dialogue of thinking and memory - thoughts and sensory experiences, namely the artistic experience is "changed state of consciousness»", but one that always has a positive sign.

So, what is the movement of «opposite rows of emotions»? It is a movement in the opposite direction compared to how it might happen in everyday life, when the most direct and easy way is the direct discharge of lower emotions. The most complex dialogues we have in our lives are the dialogues with consciousness, or rather, with our unconscious. But these are the dialogues that, according to Vygotsky, help us to improve, that is, to reach a fundamentally different level of presence in life, to achieve co-existence in life.

After analyzing the fable, with its parable instincts and capabilities, the work "Psychology of Arts" offers a special way of 
analyzing the novella (by genre definition of Vygotsky) - an analysis of I. Bunin's story «Light Breathing» ${ }^{113}$. The main method of analysis is that Vygotsky contrasts as material and forms the «disposition» and «composition» of the novella, story and plot, that is, an event series that can be extracted from the content of the novella: at first, in the order in which it would be presented in life, in everyday experience; then Bunin, that is, already subject to the compositional logic of the novella. The very name of the novella - «Light Breathing» in comparison with its event series creates an unsolved contradiction, because what is stated in this novel can not be called in another way by «life turbidity». It is the method of compositional construction that gives Bunin the opportunity to turn this «muddy life» into «light breathing», which Vygotsky considers to be the main cathartic technique in the novella composition.

How does Bunin achieve this? The first technique, the most obvious, among which he uses, can be called «retrospective and mnemonic move». Events are not simply told from the end - from the moment of death that has already taken place, beginning with the funeral that has already taken place, with the absence of the life (and in the life) of the main character, a young high school student whose fate turned out to be extremely short. But they are presented as a memento of her classy lady, whose entire life is the exact opposite of the young heroine's short but striking and challenging-free existence. There are no direct dialogues in the novella; Vygotsky does not pay attention to this, but suggests its possibility in connection with the characteristic of the general descriptive, narrative and mnemonic, even somewhat formalized verbal and intonational type of presentation. We are not present directly in the event chain, we are already out of bounds of these events and we cannot change anything in them; we do not participate in the events ourselves, but in the memories of them - and this fundamentally changes the aesthetic functions of the reproduced facts.

The plot of the novel is constructed in such a way that, starting with the death of a young high school student, we end with the presence when talking to her friend (this is the last episode of the

113 Выготский Л. Психология искусства. М.: Искусство, 1968. С. 187-208. 
novella), that is, the presence in her life. In this conversation, the heroine mentions the qualities that must be in a real beauty (she long lists them), and also she assumes the need for «easy breathing» and asks her friend: «Listen to me: is it true, do I have it?" Thus, indirectly, Bunin points out that the heroine was such a «beauty», and not so much externally, but by the sense of life - a way of life existence, which was interrupted unexpectedly catastrophically. One way or another, but we go (after the writer) from death to life, and Bunin leaves us at the moment the heroine's death, and leads from it, leads persistently - to the image of «light breathing» as a sign of immortality, that forever will remain in the world after leaving the life of a young high school student; and that's how her class lady mentions her. For her, Olga Meshcherskaya remains forever vaguely vivid, brilliant, somehow «light breathing» of life - in comparison with the everyday life of the class lady. It is that attractive and impossible for her existence, which she remembers with sadness and, at the same time, with joy. And so Bunin writes that now that light breathing has dissipated in this world, in this frosty air, reaching eternity...

It would seem that a single technique of composition arrangement from the final life episode to its initial phases cannot organize a holistic aesthetic impression, but for the artistic form this technique proved to be extremely important. An essential feature of overcoming material by form is the arrangement of material in time, that is, the organization of artistic time as existing under its own rules. Our world and we exist in time. Our relationship over time is very complicated. Our usual condition is that we do not notice the time but do not keep up with it; it is ahead of us. We look at the clock, but do not think about the passage of time every minute, the more we do not record the relationship with the past, present and future at each moment of their existence, and in the meantime, this moment is determined by them.

One of the most difficult issues for human consciousness and art is the question of transformation and subjugation, development of time. Therefore, the main object of Bunin's story was time - in its artistic sense: as time that flows backward through the will and desire of the artist. The reverse of time creates the main cathartic effect of the novella; we can say that the leading theme of this novella is the theme 
of immortality. What is immortality if we bring it closer to our value definitions? This is our opportunity to make time «flow back». It is not possible stop the progress of time, but it can be transformed, slowed down, speeded up, and quickly reversed; and only memory can really turn back time.

In this constitutional feature of the novella - in retrospect and mnemonic course - there is another very important genre condition. Novella is lyrical; its «reverse logic» is what the lyricist can afford, because the sphere of the lyrical is, by definition, the experience of internal reasoning, speculation, personal approach, that is already passed through the sphere of memory. Let us assume the courage to say, lyrical in art is always a sphere of memories, that is, a reproduction of what has already been and has been exactly with us.

The aesthetic law of tragedy, which is revealed at the culminating stage of the analytical section of L. Vygotsky's study related to W. Shakespeare's "Hamlet", 114 is quite different. Even a formulaic one, like a retelling of a Bunin novella, retelling of Shakespeare's tragedy is quite difficult to do. But one feature of the tragedy cannot be overlooked.

Tragedy as a genre form requires a consistent, close to life - to real time process - unfolding of events, which should come to the death of the hero or to some final stage of his biography, life path, destiny - at the last moment, in the last scene, on the last pages. If this happens earlier, there will be no tragedy. Tragedy must prove by the irresistible strain of the reader, the viewer, the listener, until the moment of a crisis event, to a crisis «point» in the fate of the hero and at that moment to «throw» it, to interrupt; therefore, remembering the tragedy is the most vivid, and therefore the perception, the experience of the tragedy is considered one of the most difficult. And the construction of the novella, which Bunin offers us, reveals a clarified and claritative - «enlightened»-catharsis. The difficulty of tragedy lies precisely in the fact that its catharsis, its cathartic idea are difficult, hidden, veiled - and not only because the very death of the hero must terrify us, but also because tragedy leads us to catharsis in the most difficult contradictory ways. It is these structural and

114 Выготский Л. Психология искусства. М.: Искусство, 1968. С. 209-246; 341-496. 
semantic contradictions of tragedy that Vygotsky explores in «Psychology of Arts» on the example of «tragedy of tragedies», «Hamlet» by W. Shakespeare.

The researcher asks two main questions. The first is: why, throughout the tragedy, Hamlet is delayed when it appears that the nature and order of his actions - the necessary actions - are quite obvious? Second is: why, despite this slowness, does he make hasty, wrong, erroneous actions, accidental killings, behave inappropriately to what is happening around him?

How does Vygotsky answer these questions that he has been asked?

In the first case, he points out that Hamlet's slowness is what Shakespeare needed: Hamlet is afraid of what Shakespeare wants. It was this slowness, the irregularity of Hamlet's behavior that deeply angered L. Tolstoy in his time, as a sign of the wrong artistic construction of the tragedy. He believed that admiring the Hamlet tragedy as a work of genius was a conspiracy of mankind to refuse to see Shakespeare's play as a frankly bad, weak thing. He perceived the content of the tragedy rationally, abstracted from the sensual fabric, «literalism» of the plan. Meanwhile, Hamlet's slowness gives Shakespeare a great opportunity to saturate his text with lengthy monologues: if Hamlet had not been delayed, he would not have had time to say all that he had time to say. But most importantly, as it turns out at the end of the play, he did not express the most significant. An important line of reasoning for Hamlet, the terms of his behavior can be clarified by the phrase Shakespeare said in the comedy «Twelfth Night»: "We are such stuff as dreams are made on...»

So what are we made on? Dreams, somnambulistic states, visions and so on, as recognized by all psychologists, are the realms of the unconscious. Hamlet's problem is that he is trying to find a connecting thread between the two worlds; and it would be too naive to look for them outside. These are the worlds of consciousness of Hamlet himself - his day and night, his twilight consciousness. The day belongs to the court life, the Mother, the Queen; the night is completely in the ghost's power. The best thing about Hamlet is probably his skepticism, the fact that he does not fully trust any of these worlds. If he had obeyed the Ghosts and immediately did what 
he said, the tragedy would simply not have happened (nothing to write about for Shakespeare). On the other hand, he also cannot ignore the ghost's command. In addition, let us look at another interesting moment of the tragedy: the ghost is seen with Hamlet guards, but only he hears it... That's how indirectly Shakespeare indicates the musicality, the auditory perception of the cherished sense of the tragedy. Coming out of his life, Hamlet says that he could still say so much, but death is a «strict prisoner», which makes him hurry, so «further - in silence...» (turning to Fortinbras - and it seems that because of this latest appeal by Hamlet Fortinbras was placed in the tragedy)

L. Vygotsky writes that the tragedy was born of silence - the silence of the Ghost, impaired by hearing, the ability to hear Hamlet and then goes into silence. This silence is a vast sphere of hidden possibilities, a sphere of the unconscious, from which personal experience is formed and into which it is, ultimately, hidden. Where does this experience lead, which are the hidden forces of the subconscious, especially in its higher - top - capabilities; this question remains open: further - in silence.

Why, after all, does Hamlet do reckless acts? This line of tragedy (the accidental killing of Polonius, fighting, the enmity of Laertes, whom he loves as a brother, the «outrageous» behavior with Ophelia) - is Hamlet's defiant behavior, which does not inspire even the most condescending viewers; everything is used to make us hate him, a line of a hero, who does everything contrary to our positive attitude towards him, is built up. And this, too, is needed by Shakespeare, Vygotsky declares, in order to split the semantic meaning of the tragedy and evoke opposite rows of emotions.

The external plan of Hamlet's behavior, his actions, in isolation from the monologues - is that everyday experience, the involuntary, instinctive manifestation of the hero, which inevitably leads him to death. Hamlet programs his own death, and with each step we approach it together with Hamlet, and with each step our tension and associated negative, though artistically transformed complex of emotions - compassion, fear, regret, etc. - is growing. At the same time, listening to Hamlet's monologues and observing this internal line of tragedy, perceiving its music, we understand the main personal meaning of the tragedy - Hamlet's capabilities, human capabilities 
as hidden, endless, enormous, grasping the inner beauty of man. And our passion for Hamlet is growing. So there is a double conditionality of our experience, two of its directions, which converge as in the solution of the cathartic line in the scene of King's assassination by Hamlet.

Vygotsky pays special attention to this scene because he notes the fact that has been missed by all other art critics. Shakespeare shows King's double murder: he's already poisoned, but Hamlet kills him with a sword. This double murder is necessary in order to take place on both sides, on the sides of two artistic lines of tragedy - internal and external. The tragedy closes, converges at one action point.

Of course, the important thing is that King's murder is carried out by Hamlet, who also dies. Life in him, as he says, remained for half an hour. And in these half an hour, he finally does what he was called to do in the beginning of the tragedy - he has time to do it all in those half an hour, which explains the particular tension of the denouement and its open character, since the main thing he sought to express, Hamlet leaves beyond the tragedy (for this he does not have time!).

Every time we reproduce the artistic model of the Hamlet tragedy, we are convinced of its semantic inexhaustibility, of the complete openness of its content and of the ability to embroider many more concepts in its fields. This breadth of understanding of the imaginary conflicts inherent in the content of the tragedy, determines that for Vygotsky the tragedy way of catharsis is the most interesting. In connection with it, he writes that the monotheme of death is the monotheme of tragedy. In our view, however, the monotheme of the tragedy, which really emerges from the death of the hero, brings the hero to a critical deadly situation, is still a monotheme of Eternity that is, reached past time, unity of the past, present and future, so Eternity not as the future, but as a Sustainable Present. This tragedy realizes its monotheme due to the fact that it breaks into the most responsible and critical, into the highest moment. Everything else the viewer has to think of the author, so the perception of tragedy really comes «lane of silence» - as a lane of aftereffects.

And what happens in this «lane of silence»? Meeting with oneself, meeting with the reserves of one's own consciousness, one can say «memories of oneself», focusing on the complex and responsible mechanisms of one's personal consciousness work. Of course, the 
tragic work illuminates our inner world most deeply; it confronts us with the problem of the finality of our personal existence, with the problem of our temporal limitedness - and there is nothing we can do about it. The only thing we have power over this problem is in the ways of understanding it, that is, in the ways of treating it, its experience, to which our consciousness is capable of imparting a transformative purifying power. That is why in art tragic cognition and experience of catharsis form an integral whole.

Thanks to the tragedy of aesthetic attitude embodied by artistic means, one can understand the psychological nature of catharsis.

Catharsis is a productive silence of understanding, which is achieved by the completeness and isolation of the artistic form; to find it, to identify the main purpose of the artistic form helps to study the principles of artistic completeness. Not by chance L. Vygotsky paid special attention to the final episodes, scenes. However, the artistic image at any time of its formation is the completion with the help of artistic composition of both «uncertain» life phenomena and revealed but ambiguous, open artistic and textual ones. Thus, the principles of completion form their own logical system that operates at different stages of the compositional realization of an artistic idea.

In the context of musical creativity, this system is considered by us to be a cathartic conventionality of a self-dialogue of music, based on the transitive properties of a composition of a musical composition. We outrun its characteristics with a number of generalizations that allow us to identify those issues and methodical «difficulties» that remain after discussing the concept of catharsis by L. Vygotsky.

Catharsis - purification (Greek) - is possible not only in artistic form but also in those relationships for which aesthetic is not dominant, for example, in religious experience. It can even be said that, first of all, catharsis is associated with religious experience, gradually emancipating itself from it - together with its aesthetic attitude - into the field of autonomous art. However, it should be noted that religious systems, for their part, have always used artistic elements, whereas art does not always refer to a religious theme and religious symbolics, and if it does, it provides them with a more free, fideistic interpretation (as, for example, in the works of M. Rimsky- 
Korsakov) or «free-thinking» ethical interpretation (as S. Taneyev does in «On Reading the Psalm»).

The historical development of man in culture and with culture leads to a growing division of both forms of activity and forms of consciousness, to deepening specialization and increasing the distance between different cultural institutions, as well as between the specialized spheres of work of individual consciousness. The catharsis is formed in connection with the need to restore the integrity of consciousness, the unity of the fideistic, cognitive and «understanding» of its levels, directions. At the same time, the definitions of catharsis as "purification» by faith, knowledge and understanding in their isolation remain true, because each of these «purifies» has its historical and psychological way.

Thus, the way of knowledge is initiated by the objective reality of facts and thoughts, theories, logical circuits, and so on - «alien», but appropriated in the process of overcoming «own» non-knowledge. The way of faith, dictated by the need to strengthen it, proceeds from faith: unbelief does not generate faith, just as non-knowledge stimulates the search for knowledge. Faith is always «own», an inherent personal phenomenon of «spiritual inspiration», but it seeks to be realized in an increasing number of life objects. The way to understanding begins with equilibrium in «own», and in "alien" comprehension - incomprehension, forked, acquiring a dual logic initial and reverse. Comprehension is always between own as alien and alien as own, that is, it implies instability, the transience of these boundaries, and therefore we have an urgent need for an aesthetic form of dialogue that transforms it from an act of communication into a semantic noetic phenomenon.

Dialogue engages in religious and cognitive relationships as an understanding. In general, catharsis, by removing contradictions, taking away opposites in a holistic experience, is anti-antinomic, but contributes to the identification of antinomic values of sense and needs them - to restore, expand, and integrate the «working zones» of consciousness.

Art is therefore, above all, an experience of understanding, and catharsis becomes for it the main «technique» (according to Vygotsky). The functions of catharsis that are formed in the process of artistic influence are revealed as experiences (emotional response 
to imaginative and sensory stimuli), learning - memories, actualization of semantic memory with its logical operational capabilities and conceptual orientation, co-creation - perception of the whole, «psychology of the whole».

In the logic of musical and compositional endings, endowed with cathartic functions, as the leading factors there are distinguished: literal voice unity of the vertical - monodic statement, unison and tuttian constructions (for symphonic oratorial sphere), thematic endurance of horizontal, mastering of thematic ordering polyphonic), development of the consonant sphere, stylistic significance of the composition, techniques of monotematism and polystylistics, quiet loud dynamics, pauses, methods of sound and sound matter production - articulatory techniques.

According to this set of logical receptions, determined by the leading genre forms of music, catharsis in music manifests itself in several compositional and semantic positions: as declarative, directly represented, stated by a number of known techniques; clarinative by comparing different sets of techniques, however, also by retaining elements of declarativity, for example, at the moment of final approval (tonic); veiled, detached, based on an awareness of the stylistic unity of the composition and the meanings of stylistic techniques ("play" with style) upon completion of the work; in this case, however, it is also possible to participate in claritative compositional functions; eliminated, which implies the complete avoidance of recognizable expressive techniques and the usual associative ways of perceiving music, originates «in the bowels» of previous ones, achieves independence in connection with a new understanding of musical dynamics.

Named types of catharsis, acting as components of the general compositional logic of music, correspond to the main varieties of semantic dialogue identified in the study of A. Samoilenko ${ }^{115}$, as a means of dialogical communication aimed at the detection of semantic Over-addressee. Thus, «dialogue of identification» and «dialogue of agreement» are characterized by a declarative form of catharsis, «dialogue of unidentification» and «dialogue of

115 Самойленко А. Музыковедение и методология гуманитарного знания. Проблема диалога. Одесса: Астропринт, 2002. 
difference» - by a clarinative, «nostalgic dialogue» and «dialogue of silence» - by veiled, "prognostic dialogue» and «dialogue of the deaf»- by eliminated.

On the whole, it must be confessed that the problem of catharsis brought together the efforts of many humanities - philosophy, aesthetics, ethics, psychology, ethnography of art criticism, but none of them found a convincing final solution. Methods of scientific and theoretical disciplines are unable to overcome the mystery of catharsis, the strange uncertainty of the phenomenon and the concept of catharsis, which is combined with the extreme importance of this psychological phenomenon. In our opinion, the reason is that the riddle of «purification» is connected with the ontological properties of man, with the unethical nature of human relations, culture. Therefore, it is subject, rather, not to rational scientific knowledge, but to spiritual entry understanding. Therefore, the interest in catharsis is deeply supported in «Living Ethics» by N. K. Roerich - and not only in it, but in other books of this scientist and artist left for us.

The «Living Ethics» of N. Roerich suggest the legitimacy of a particular, with no appraisal, area of catharsis conception; it already suggests the strangeness, the transience of its form. «Living Ethics» is not a scientific work, but it is not a poetic work in the literal sense of the word; it cannot be regarded as an artistic opus. At the same time, it is a special text which contains such symbolic definitions that are closest to poetic and aesthetic in their form and influence. Roerich's «Living Ethics» could be called Living Aesthetics, Living Poetics, finally, Cathartic Poetics... Roerich himself considered it a «wayfarer» given «for the way of the far». What connects Roerich's teaching with the problem of catharsis, what place and why does the concept of «purification» occupy?

Roerich uses the Greek word «catharsis» in his Russian-language translation and saturates every page of «Living Ethics» with the concepts of «purity», «purification», lining with them the peculiar semantic paradigm of this work. By discovering the plural meanings of the word "purification", he reaffirms his view that "the word contains a thousand thoughts. Too gross to attribute the word exact 
expression ${ }^{116}$. The ambiguity of purification is revealed by such verbal formulas as: «Pure phenomena create a miracle»; «It is necessary to work with a pure spirit, the rest will come without difficulty»; "... Poverty is a cover - a gift of purification"; «Pure thoughts of music help transmit stream»; «... the habits left are purifying the spirit»; «The purification of religions implies a new direct relation to the spiritual world»; “... Quality of action is a pure departure"; «Pure thoughts are like the ozone of space ...»; “... It is important to purify consciousness from the self"; «Only accelerated purification will enable the planet to save it...»; «Let people not complain but live cleaner» and many others ${ }^{117}$.

Roerich's peculiar manner of speaking is not even aphorisms, but sentences. It is difficult to agree with the researchers (despite the depth of knowledge of their life and work of Nikolai Konstantinovich), who considered Roerich's type of thinking as «parable». The parable tends to be limited to metaphors, comparing and bringing together, on the basis of the figurative meaning, two phenomena, giving the name one of them. Roerich's language is much more complicated: it turns from a parable to a myth. The concepts Roerich uses are no longer metaphors, but very complex symbols; they become symbols, owing to incomprehension, extraordinary brevity, down to a paradox: the smaller the words are, the more the content is, the more boundless this content is and the more difficult it is to decipher it.

Reading "Living Ethics" any reader, even the most prepared, faces the problem of overcoming abstractness, the conditionality of its content, for example, concepts such as Infinity, Joy, Beauty, Service, Sacrifice, Power as Sacrifice, Orientation, Oneness, Benefit, Holiday, High Light and others; moreover, all important nouns are written in capital letters, every word is an event. But the author presents this event as a given, without comment; all comments are hidden in the subtext, or in the context in which Roerich's thoughts were born. Continuous contextual and objectification of the concept of purification provides a broad understanding of this phenomenon. According to S. Averintsev, sense formation in its verbal forms can

${ }^{116}$ Рерих Н. Живая этика. Избранное. М., 1992. С. 128.

${ }^{117}$ Там же. С. $11 ; 15 ; 16 ; 17 ; 22 ; 54 ; 76 ; 99 ; 317 ; 331 ; 343$. 
occur in two ways - by «over-warming» and by «cooling». More often than not in everyday language, the meanings of the words «warm up» become mobile and malleable, just as they become warm when forging a metal billet, becoming soft, melting, able to take on a new shape. In the scientific and logical dictionary the word «cools», because here it must acquire a strictly fixed position of the concept and term. Significant regularity - the «firmness» of scientific categories, leads to the fact that many phenomena in the world can not be explained only with the help of such categories... Therefore, S. Averintsev saw the need to create a special «other-scientific symbolology», as the language of discussion of complex spiritual relationships (though he did not explain what he meant by that).

In Roerich's "Living Ethics", the concept of catharsis (purification) is in a state of «warming», enabling us to change its «form» depending on our need for its semantic interpretation. By «warming» the catharsis, Roerich creates new reasons for his understanding, leaving, however, the choice of the way to this understanding by the free, wholly conditioned spiritual gift of the one who chooses. In Aristotle's vocabulary, from where it came to scientific life, the concept of catharsis experienced a reverse transformation.

The formula of tragedy, proposed by Aristotle in «Poetics» («... tragedy is the imitation of important and complete action...» and so on), became famous, thanks to its ending: «... by the means of fear and pity the purification (catharsis) of such affects" $" 118$. Aristotle assumed some carelessness when he replaced the effect of catharsis, well known to the Greeks, into the sphere of emotional and psychological impact (perception) of tragedy. Most of the researchers who push away from the Aristotelian «Poetics» narrow the problem of catharsis to the limits of the partial question about the content of fear and pity affects and the possibility of overcoming, displacing (or rescuing them). Thus, there are numerous psychological, psychophysiological, even psychotherapeutic (Freud's method should be recalled) versions of catharsis that promised him to stay in this limited plane for a long time.

118 Аристотель. Поэтика (Об искусстве поэзии). М., 1957. С. 56. 
It should be also noted that, unlike some Western psychologists and aesthetics that see the useful properties and even the necessary ontological characteristics of a person in a feeling of fear, N. Roerich treated this kind of experience unequivocally negative: «We constantly insist on overcoming all fear. This requirement is not abstract, but aimed at the nearest one of yours. Fear, like many negative properties, intensifying, form a kind of negative magnet... Therefore, it is useful for a person to realize the intactness of their spiritual essence, now he has freed himself from all fears. Because all intimidation is not significant ...» ${ }^{119}$

In order to understand what the catharsis was for the Greeks, it is necessary not to forget about Aristotle, but to some extent distract from his «Poetics», because in it the word «purification» «cooled» and took the limiting form of the term that it, as a whole, keeps nowadays. Even more important to the «complicated» fate of the problem of catharsis is that, because of Aristotle's authority, the phenomenon of purification seems to be forever entrenched in tragedy, in tragedy as a particular artistic phenomenon...

The source of «purification» and the sphere of understanding that determined the content of catharsis are, of course, not only the «Poetics» of Aristotle, not only ancient philosophy, but the whole life of the Greeks, all Hellenistic culture. And not only Hellenistic culture - the most ancient, constant and developed sphere of ritual practice of man were the rituals of purification, as evidenced by ethnographic, archeological, historical literature. Already an ancient person felt the need to draw the line between life and death, to get rid of the bad death and the things connected with it - from illness, infirmity, injury, and similar. The concepts of purity and purification are immediately connected with one's attempts to find immortality, or at least to postpone death. In order to get rid of the evils that can be transmitted from the individual as a whole and destroy it, there were rituals of «purification». Their history and structure are diverse, but they always retain one peculiarity: these rites involve sacrifice, which provides the necessary purification effect.

${ }^{119}$ Рерих Н. Живая этика. Избранное. М., 1992. С. 239-240. 
In ancient communities, such victims were first identified as "culprits-exiles" whose very choice is already to hold them accountable for all the bad things that have happened or may happen to the native (or in nature, for example, as long-running rain, or no rain etc). If the guilt of such victims is fictitious, then their fate is connected with a very real cruel violence against them: they were expelled with shame outside the settlement and killed there - with stones or canes.

From this rather bloodthirsty first form of sacrifice, the rites of purification rise to the second: there appear sacrifices-»choices», sacrifices-ısaviors»». If the individual who takes responsibility for the fate of the family guarantees this purity and immortality in all his affairs in the future, then he will become a reverent figure to be bowed to. The ritual killing for such a sacrifice, which is still preserved, creates a new problem for the genus - because it is no longer the carrier of «impurity» that is killed, but the carrier of «purity»; so the rites of purification create quite a precondition for the tragedy.

The third historical form of purification rites is related to the third type of sacrifice, which can be seen as a distant prototype of the Roerich's understanding of sacrifice - with the sacrifice as spiritual authority or the Authority as the Sacrifice. This type is represented by victims - «witnesses», people who, because of their special spiritual gift, in the words of Paul Florensky, are «able to testify to the truth» and fight for it at any cost, to fight joyfully without fear of giving their own lives. Such an understanding of sacrifice in the future will turn to the Christian religion (perhaps not only to the Christian one), but it will also translate into the ancient Greek idea of the year, which defines the main content of the ancient tragedy.

The connection of the idea of the year with the ideas about the fate of the «World Mind»- Noosa emphasizes the expediency of the noological interpretation of the catharsis proposed by A. Losev and, it seems, the closest to the symbolic complexity of this concept. Losev goes beyond «Poetics» and notes that the concept of purification in Aristotle is closely related to the concept of Noosa's selfdevelopment, and hence - to the concepts of mimesis (imitation, the key to all Aristotle's aesthetics), good, joy ("harmless joy", as its philosopher indicates in "Politics"), a self-sufficient enjoyment (bliss 
that is superior to all available human feelings, since it is gifted with attraction to Noosa). The main point in the noological version of Losev's catharsis is that the chain of tragedy events - the tragedy itself - is revealed by only one episode - a stage in the cathartic selfassembly of the World Mind. At the same time, the whole world turns out to be a tragic whole, and from the tragic in its broadest sense, there is simply nowhere to go... Man exists "in a zone of constant tension", "between Eternity and the vital determination of the mortal person" (M. Bakhtin). This is an aesthetic, spiritually generalizing experience available to man. At the tragedy stage, Noosa selfdestructs, self-afflicts the most difficult and contradictory realities of life; but this self-destruction, as a distortion of Noosa's initial purity, is a prerequisite for a new finding of integrity and purity. From this (tragedy) moment, as from the point of the deepest loss of self, Noosa returns to self-sufficient bliss, a cathartic recovery.

One of the important categories used by Roerich is the category of Truth; it is in harmony with the concepts of purification, purity, cooperation, orientation, attentiveness, vigilance, cosmic pattern, the Hierarchy and others. However, Roerich does not disclose its content, but only symbolically indicates the ways to it, in this regard also picking up the principle of aesthetic incompleteness of the theme of the Year, which we find in the ancient tragedy. The contradiction of the final solution of the tragedy, at the same time, its emphasized cathartic orientation is explained by the fact of the death of the best of the heroes, the necessity of which Aristotle insisted on for the tragedy. The death of these heroes involuntarily contributes to the concealment of the Truth for which they sacrifice themselves; Truth is surrounded by unspokenness - ineffability, because it is «... sound not for the ears of the earth». Such an interpretation of the theme of Truth brings together the images of Oedipus and Hamlet, as well as the final episodes of both tragedies. In "Oedipus" by Sophocles, Truth is associated with inner vigilance, attentiveness to everything that goes on around, with the ability to penetrate beyond the superficial combination of events. Vigilance comes to Oedipus when he becomes physically blind, voluntarily giving up his sight (rolling his eyes). Thus, comparing himself with the blind prophet Tiresias, Oedipus counteracts the physical ability to see bodily injury and, at the same time, new spiritual freedom and vision. Blind Oedipus, in 
the second part of the tragedy, begins to mature gradually, mastering his inner vision. The lonely way of Oedipus is the way of the victimwitness who leads his Battle in Solitude, affirms «purification from self» as a heroic action. Reconciled to the gods, perceiving Fate as a cosmic justice for which there is no division for good and evil, accepting it, expanding consciousness to Comparability with it, Oedipus reveals a secret knowledge that can pass to only one person - the hero Theseus. He does not take his children into consideration because they are too weak. The moment of his death underscores the mysterious significance of his departure, exacerbated by the horror that grips Theseus remaining. Oedipus's words, in which he conveyed his knowledge of Theseus, are not in the tragedy. Their content, on the one hand, was taken away by Oedipus, for whom there is no return; on the other, it will forever be kept secret by Theseus, who appears as a Witness... It seems that this final scene inspired Shakespeare as he finished his Hamlet by saying: "Further in silence".

According to the word Truth, this symbol in Roerich "Ethics" also comes with silence, because that mysterious spiritual action, which must take place as the cathartic, always takes place in inner silence, in meditative peace.

«... Sound can be as inaudible as heart rate», Roerich wrote ${ }^{120}$. The desire for cathartic symbolics as the Absolute Sense led to the emergence in the music of the XX century a special «music of silence» (the most directly and flamboyantly presented in the play by J. Cage «4.33»). The desire to translate the catharsis with the means of music is associated with new programmatic trends in the composer's creative work of the second half of the XX century, including interest in music as a «relevant and beautiful» sounding phenomenon. They are expressed, in particular, in the return to the prayerful purposes of music; in the development of its sonorsonoristic properties; in neoclassical orientations (allusions, stylistic syntheses); in the transformation of the functionally harmonious foundations of music, in the «emancipation of consonance».

${ }^{120}$ Рерих Н. Живая этика. Избранное. М., 1992. С. 345. 
The teachings of N. Roerich approach to understand the catharsis as an expression of the spiritual integrity of man and a sign of his involvement in the Higher Truth, going out on the Way, getting rid of being limited, from the tragic fatal conditionality of human essence. The symbolics of protection in catharsis is rotated by the phenomenon of post-tragic knowledge, which is expressed in the «pure sending of thoughts», «starry expectation», «expansion of consciousness», «comparability in Joy», aspiration to «Doors, Lights of beautiful expediency that shines» in opening the life that leads through the steps of Beauty, Happiness, in Thanksgiving (because "thankless is not noble"), in constant readiness as a harmony of consciousness. In the definitions of "purification", Roerich has discovered and called many things with utmost directness, this leaving space for the not-understood... The words of N. Roerich himself may serve as some consolation: «The not-understood today will become understood tomorrow".

\subsection{Time category and psychological aspects of musical temporality}

«Self-awareness, mind and imagination were not within the bounds of harmony inherent in animals and ultimately destroyed it. The appearance of these properties has made man an anomalous phenomenon, the whim of the universe. He is part of nature, the subject of its physical laws, to change which he can not, and yet he does not fit into the scope of this nature. Man is separated, being part of it, he is homeless, and at the same time is confined to the house, which he shares with other beings. Abandoned into this world, which he did not choose, with time and place to be accepted as they are, he finds himself thrown out of this world, out of place and space, and again not of his own volition» ${ }^{121}$.

These E. Fromm's words seem to us to be a good start to discuss the complex and contradictory relations of man to the phenomenon of time, which express the first and fundamental «existential

${ }^{121}$ Фромм Э. Человек для себя. М.: АСТ; Мн.: Харвест, 2006. С. 62. 
dichotomy» - «disorder in the nature of man», which gives rise to the contradictions of its existence, «which man has no power to solve, but to which he may respond in different ways, depending on his

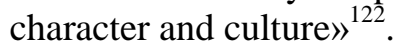

Continuing from E. Fromm's argument, let us say that involvement in the historical time of the human race (hypothetical equation to the term of being an individual) does not save a person from the difficulties of mastering time and contradictions of his awareness, because taken as a whole ancestral «human time» opposition to «space time» (P. Ricoeur's term), a space and time universe that is not amenable to human interpretation and calculation. In this connection, U. Eco points to the difference between the Einstein concept of the world, according to which "everything that for each of us forms the past, present and future, given in unity, and the totality of successive (in our view) events, which determine the existence of a material particle, represented by one line, the line of the universe of that particle ... Any observer, as his time passes ... opens new pieces of space and time that appear to him new, consistent appearing aspects of the material world, although in reality the whole set of events that make up this space and time existed before it was known»» ${ }^{123}$.

If the connection with the understanding of the phenomena of life - death (beginning - end of human existence, infinity limitedness, continuity - discreteness, interruption of human life as a reflection of the dichotomy of the common - individual in it, finally, eternity - transience, momentariness) determines the particular valueemotional tension of person's relations with time, their, so to say, aesthetic pathos, the inaccessibility of time to direct sensory perception, its impeccability and non-materiality for human reception, and hence - the impossibility of considering it and describing it as an object and assigning it to a class of objects, creates special conditions for rational and logical comprehension of this «phenomenon» (which, in fact, does not «appear» in front of man), and consequently his

122 Там же.

123 Эко У. Поэтика открытого произведения. У. Эко. Открытое произведение. Форма и неопределенность в современной поэтике. СанктПетербург: Symposium, 2006. C. 97. 
scientific knowledge, definition. With sufficient clarity these conditions are called by A. Pigalev, who, separating the concept of «time of culture», in particular, writes: «The specificity of time of culture is that, unlike material objects, it can not be perceived by the feelings, and so its image is intertwined with and determined by certain metaphors. This feature is inherent in the perception of all, without exception, phenomena and processes inaccessible to the feelings. As a result, the supersensory is replaced by something obvious, which, in fact, allows us to make a metaphor. The time of culture, in principle not being a given perception, is constituted by each culture in its own way. And this is not a trivial «marking» of some objectively existing time of culture, but rather a rationalization of the processes of formation and change, which are only given to the organs of the feeling》 (italics is ours $-A$. S. $)^{124}$.

Thus, «the subjective perception of time and its objective presentations are closely interdependent, which is manifested not only in the objectification of subjective images of time, but also in the influence of theories of the time essence relevant to some culture ... on its perception by people, belonging to this culture» ${ }^{125}$. A. Pigalev rightly concludes that since $\ll \ldots$ all its (time $-A$. S.) definitions are tautological and use the associated associations», so much as the essence of time tends to express with the help of features inherent in space. «The latter is not accidental, and the connection with space is one of the most significant common features of time» ${ }^{126}$.

The insolubility (inexplicability) of the human mind with the antinomy of life - death is largely provoked by the mystery of the phenomenon of time (inaccessibility and unmanageability of time as an object, which does not eliminate assumptions about its objective nature - but only as a «superhuman») and leads to the emergence of an internal «existential dichotomy» of that time, leads to its selfcontradiction as a recognizable (natural phenomenon) unrecognizable (conditional, conventional cultural and historical object with a predominant reflective function); subjectified in image

124 Пигалев А. Время культуры. Культурология. ХХ век. Словарь. СанктПетербург: Университетская книга, 1997. С. 81.

125 Там же.

126 Там же. 
and experience - abstracted by rationalization in concepts and scientific categories; absolute, «pure», ideal, amorphous, that is, free from form - materially concretized, albeit partially hypostated in the material realities of the human world, structured by spatial coordinates.

Without even trying to present in a comprehensive way the general theoretical foundations of the problem of time, which is undoubtedly meta-scientific and interdisciplinary, we still note the two main, in our view, methodical prerequisites capable of going further - to determination of musical time originality:

- in all its forms time acts as an antinomic phenomenon - both because of its reflective nature and because of the tendency of universalisation, the tendency towards universal human time. In the latter case, the time category is particularly closely related to the antinomies of being - nothingness, life - death, Eternity - transience, eschatological result - rebirth. A fundamental internal contradiction in understanding the phenomenon of time is its «translation» into the language of spatial characteristics, that is, the purpose of time in space;

- the perception of time is the perception of ideas about it, and with the effect of double reflection - object and event reality (including the experience of social relations, the realization of man in society) and psychological meaningful «inner» reality of man, «consciousness as a form of being» (L. Vygotsky). Recovering from the inner human reality, time becomes a «free», creative and conceptual, intentional subject that expresses the human right to reconstruct the life process, to organize it on new intersubjective principles. Therefore, the leading aspect of «human time» is the psychological, associated with the processes of comprehension of both the external life series, and the ways of its reflection in the human mind.

These prerequisites allow us to formulate some approaches to musical time.

First of all, the necessary metaphorical concept of time determines the particular importance of its artistic understanding and the associated symbolics. In this regard, time in music is in no way inferior to other forms of temporal representations; it generates its own temporal patterns and chronotopic dimensions, the study of 
which can clarify the general cultural concepts of time, such as its modal structure. And although U. Eco notes that «it is always risky to claim that metaphor or poetic symbol, sound reality or plastic form give more grounded means of knowing reality than that offered by logic,» he is also engaging in some controversy with himself, stating that «art does not so much know the world as it brings to it the additions created by it, its own independent forms that attach to existing ones, revealing their own laws and their original life»; and therefore, «any artistic form can be considered, if not as a substitute for scientific knowledge, as an epistemological metaphor, that is, in any century, the way of structuring artistic forms reflects (in the form of likeness, metaphorically, by putting the concept in an image), by which science, or, at any rate, the culture of one or another era perceives realityı $^{127}$.

It should also be noted that musical time is constituted by the total time of culture as a developed experience of understanding the relationship of man with time, a cultural and historical typology of temporal modality. But even more, it determines the relation of musical sounding to sense, and sense to sounding (including its «unmusical»structures, «weight», in M. Arkadyev's terminology) forms of music, representing a specific non-verbal form of musical thinking. In full agreement with N. Gerasimova-Persidskaya, we say that "... we must admit that there is also a musical thought - which is not expressed verbally, but therefore it is not less real. Then the «musical sense» will be clarified. We offer the following definition: musical sense is an attribute of a musical expression (a composition, its parts, etc.), its essence does not have an adequate verbal form and can only be conveyed descriptively, metaphorically, by analogy, etc.

But in the same way - «metaphorically, by analogy» - the musical time, and the phenomenon of «human time» as a whole, can be

127 Эко У. Поэтика открытого произведения. У. Эко. Открытое произведение. Форма и неопределенность в современной поэтике. СанктПетербург: Symposium, 2006. C. 89-90.

${ }^{128}$ Герасимова-Персидская Н. О восприятии музыки и постижении смысла. Науковий вісник НМАУ ім. П. І. Чайковського. Вип. 60: Теоретичні та практичні аспекти музичного смислоутворення. 3б. статей. К., 2006. С. 6. 
transmitted and reproduced in verbal terms. Thus, two conclusions emerge: first, sense and time in music are identified, and sense can be defined as the ratio of musical sounding to time and time to sounding with the same right as to define time as the relation of sense to sounding and sounding to sense; secondly, the sense, finding a symbolic form (not only in music and not only in art, but also in the semantics of culture), as subject to the phenomenon of hypostasis and spatialization (distribution), as time.

Thus, in time and sense in music, there are general dimensions «deep structure» and «surface structure», if we use L. Hakobyan approach to the principles of rhythmic organization of music and its terminology. Moreover, the link between the data of two dimensions can be considered precisely as the rhythm, which thus becomes the main essential characteristic of both time and sense. Therefore, the definition of «rhythm of the deep structure» proposed by Hakobyan is equally effective for both (time and sense in music): «The rhythm of the deep structure should be understood as its characteristic, which determines the distribution in time of the paradigmatic and syntagmatic positions of the elements that are part of the surface (that is, in the words of Hakobyan himself, directly given the observation A. S.) structure ${ }^{129}$. In addition, Hakobyan emphasizes that «the fundamental difference between the rhythm of the deep structure and the rhythm of the surface structure (that is, from the category of» rhythm «in the more usual sense...) is that the first is continuous, while the second is discrete" 130 .

Therefore, the rhythm, which is unique for sense and timing in music, also appears «visual» and «invisible, secretive»; installation and resultant moments that rise above (or go far in) with respect to the «surface» of the composition directly; at the same time, they are the very «surface» - as a set of textural and spatial techniques of musical text presentation. In other words, the rhythm, becoming musically pronounced, solidifies with the spatial form, although it does not end there - and precisely because of the determining role of the «deep» rhythm-sense.

129 Акопян Л. Анализ глубинной структуры музыкального текста. М.: Практика, 1995. С. 88

${ }^{130}$ Там же. 
It is no accident A. Losev singled out immanent factors of time that do not pass over the spatial conditions - rhythm, symmetry, metro-rhythmic accent - and called them necessary musical categories, which dialectically emerge from the expressive element of «pure number», if in the latter to consistently distinguish moving peace, self-identity difference and uniqueness ${ }^{131}$. Taken at different levels, in different volumes of the composition, they express the autonomous temporal idea of music, rather, the temporal factors of the musical composition lead to the meaning of «higher rhythm».

A. Losev's doctrine of musical time (musical temporality), outlined in his early work «Music as a Subject of Logic», deeply substantiates approaches to the temporal nature of music as meaningful preference, and also identifies the basic transitions of time - space in music and found criteria for exploratory evaluation of the relationship between these phenomena. Unfortunately, this work of Losev is still insufficiently studied by musicologists; we will pay attention to only two of its components, essential for the cognitive position of the psychology of arts.

As the central category of his system of theoretical ideas about musical time, A. Losev makes the concept of number as «poor quality» the main regulator of rationalization mechanism of the phenomenon of time, which has only one sign - reliance, assertion as «something» as «quality», thus, completely going from the need to contrast the quantitative and qualitative forms of time. Musical time, based on the connection of numbers with the vigor of a self-growing sense, conditioned by the nature of the number as a self-identical difference of being or «that sense», is always «qualitative», that is, creative and conceptual. Losev proposes to find»reasonable figure» in the number-eidos, which can be applied to any material, but is free from any material, and therefore is free from quantity, which is always material $^{132}$.

The embodied, intended, sonorous musical time, revealing the illogical side of the temporal process (the logical formation of the number-sense), becomes its transition and hypostasis into spatial

131 Лосев А. Музыка как предмет логики. А. Ф. Лосев. Форма. Стиль. Выражение. Сост. А.А. Тахо-Годи. М.: Мысль, 1995. С. 552-553.

132 Там же. С. 530-531. 
forms, because the pure alogical hypostasis of the number is its substance. Thus, A. Losev makes it possible to understand, firstly, how the transition from temporal factors to spatial factors occurs in music and why it is caused - while maintaining the basic temporal nature of music; secondly, the fact that the spatial conditions, the compositional substance of music, is a kind of hyponym for the temporal parameters of music, can only be considered on their basis and after them.

However, many authors, focusing on the phenomenon of time in music, focus their attention on the spatial properties of the composition, and, being limited to them, do not reveal the true essence of musical time and come to the methodical inaccuracy of erroneous conclusions. For example, V. Martynov, easily changing the category of musical time by spatial characteristics, does not return to the first one, which, obviously, compels him to write that time is absent in Palestinian music, since space is united and not dissected, and space in works of Beethoven, due to its infinity and continuity, ceased to play the formative role it played in Bach's music ${ }^{133}$. There are many examples of this kind of musicological "weirdness"; however, that is not important now, but rather important is those concepts that confirm the comprehension of musical time as an ideational semantic phenomenon that becomes analytically accessible through a specific embodiment («real» expressiveness) of the spatial and compositional way - and A. Losev's conception is one of them.

The common concept of most music studies is the double concept of «time and space of music», which, when discussing or analyzing music material, often leads to the phenomenon of time or becomes an excuse to «lose» it in the territory of the musical space, that is, in fact, becomes «single», in connection with the above-mentioned features of musical time, suggests the replacement of the phrase «time or space of music».

At the same time, it is advisable that some of the paradoxes of the proposed wording are, at first, that it indicates the impossibility of simultaneously considering time and space in music - as it is

133 Мартынов В. Время и пространство как факторы музыкального формообразования. Психология художественного творчества. Минск: Харвест, 2003. С. 130-144. 
impossible to contemplate two sides of one coin simultaneously; at the same time, emphasizing their interchangeability and inseparable unity - which side does not come from, the medal remains a medal; secondly, precisely because musical time is accessible only on its hypostatic «surface», it requires a special prolonged study of its «pure» semantic form - on top of specific compositional and other techniques, starting from them - in the context of the symbolic possibilities of music and with return to its specific structural and semantic conditions.

Therefore, time in music is a projection of the musical creativity of the general principles of relations with time, ideas about it, quantitative and qualitative parameters of its characteristics. It is an expression of the time of culture, that is, subject to universal cultural and historical metaphors in defining time. And for music, the idea of time as a sequence and ordering of events, facts, phenomena, relationships, and of course, an idea of their causality, so to say, of the causality and teleology of the human world (which does not fit in «earlier - later», «before - after», «beginning - end» schemes).

Musical time brings its own order, establishes its own artistic conceptual sequence of time moments and their relationships, including rethinking different moduses of time. "Time control was not given to music. The principles of time management and awareness of this task have a long history. This process reflected the movement of human ideas and ideas about time - one of the most complex, painful mysteries of philosophy and religion - associated with the worldview of different eras and at each stage identifying some essential features of musical thinking and styleThese words of Orlov want to be supplemented by the idea that, due to the essential features of musical thinking and style, «style of worldview» and leading ideas of culture are formed; in other words, music creates its own autonomous models of the temporal process, trying, if we recall the words of I. Stravinsky, to bring order to everything existing, including the relations of man with time.

From various points of view V. Sukhantseva wants to consider the temporal content of music, fairly paying attention to the importance of the processes of styling and stylistic modeling. Yes, she identifies three «circumstances» of musical intonation: 
At first, «from lingual intonation musical intonation distinguishes because it represents the process of emotional and psychological states of man...; in this sense, concrete intonation really allows to reconstruct the artistic and worldview entities of an era. Thus, Beethoven's intonation is able to awaken all aesthetic associative series of Schiller's pathetics, Goethe's romantic rebellion, up to the grand constructions of Hegelian dialectics in the skilled listener";

Secondly, "... musical intonation, in all its "brevity", is procedural, because the temporal side of the psychological process is always present in it. We can say that the musical intonation is constantly the transition of cultural and historical time to the psychological time of the individual: no matter how large and socially significant content, for instance, Beethoven's Ninth Symphony, their perception, finding in the process of listening of the personal sense is conditioned by the "inner" nature of musical perception. The point here is also that the panorama of social processes embodied in the symphony is revealed to the listener because of the composer himself, and the "intonational vocabulary» of the era finds a subjective meaning in the intonation as epochal as the author's";

Thirdly, intonation "becomes a musical language, that is, a way of expressing and transmitting meaningful information when it is framed in time according to the laws of musical logic and musical rhythm. B. L. Yavorsky wrote about it: "Musical language is a person's ability to express him. This ability is exercised by a person through the dismemberment of an infinitely-disappearong time by sound design"'"134 (here and higher italics is ours - A. S.).

Perhaps not with complete clarity, but the above-mentioned regulations testify to a «meeting» in music of three forms of time (as forms of its conception and presentation) - a historical «cultural time», personal psychological time and, actually, musical time - an immanent logic of the music and time process. Each of them contributes to the formation of musical symbolics; the latter is an integrative and final «effort» of the previous ones, which translates them into the level of «musical thought» (we should recall the statement of N. Gerasimova-Persidskaya).

134 Суханцева В. Категория времени в музыкальной культуре. К.: Лыбидь, 1990. C. 131-132. 
Thus, musical symbols can be regarded as a kind of metaphor of time, time both cultural and historical and individually-psychological, and these two sides of musical symbolics - as two hypostases of time in music - exist in a continuous mutual transition.

The problem of musical time has its implication in the historical life-world of culture insofar as it is not only a matter of communication, but (and this is much more important for symbolic artistic experience) the duality of the processes taking place in the world (at least as the conjunction of the beginning - the end, limitedness - infinity) and the ontological antinomy of man. In artistic creativity, this duality is expressed in the historical paradigm «tradition - innovation» and in the parity of phenomena - concepts of genre and style.

The relationship of genre and style form the «great» text and the «great» time of music - its historical rhythm as the order responsible for the musical sense-creation of the moments; the mutual arrangement of stylistic figures - style signs within an individual work forms a compositional rhythm, including the «higher rhythm»the author's aesthetic idea as an individual concept of «great» temporal possibilities of music.

Thus, in musical stylistics it is possible to find a spatial expression of the laws of musical temporality caused by genre factors of musical creativity. But it, in a «big» dialogue with music, shapes time as a choice and distribution, coordination of significant moments of musical sounding, rhythmization of sense manifestations.

In music, both in composer's and in performing, style signifiers and stylistic signifiers, crowning the interpretation (perception or refutation) of genre conditions and canons of music, are signs of both historical (culture) and personal (psychological) time, depending on their level of generalization. On their basis, there may be $a$ conceptualization of time or - a semantic filling (fulfillment) of creative time in music as an artistic expression of its (time) antinomic existential and dichotomous nature. It is no coincidence that G. Orlov offers a general definition of music in terms of its temporal parameters: "... Music can be defined as a way and result of the division, ordering and organization of time. Sound - the sensual material of music - materializes time, allows to put it under control, 
give it all sorts of figurations, and then - to «stop» its elusive and inevitable flow in imaginary, conceivable crystalline structures"135.

To these words of $\mathrm{G}$. Orlov I would like to add: music is structured in sounding and thus meaningful time insofar as - and above - puts its «order» to the feelings and thoughts of a person, bringing its consciousness to the sense, and sense to the consciousness, carrying out the «secondary creative synthesis» of the emotional content of consciousness, due to the deepest need for the transformation of «lower types of energy, unspent and not found in the normal (everyday $-A$. S.) activity of the organism in higher species...». It can also be called the need to analyze the deep content of consciousness at its «top» levels, if we recall the words of L. Vygotsky about «the collision of unrealized subconscious desire with the conscious part of our behavior» as an expression of the need for creative self-realization ${ }^{136}$.

Thus, from the «pure» musical time, the psychological aspect of cognition of this phenomenon is emphasized, which allows to find in it a kind of «psychological tool» of music, an internal technique of musical consciousness, which allows to understand musical sounding as a special «transformation of consciousness» - its achievement of "top possibilities" of catharsis.

Of course, it is difficult to consider all, worthy discussions, parameters of musical time. The main thing that I wanted to say: «time» is a methodically necessary category of psychology of arts and musicology in their subject and cognitive unity. This category allows to take a deep approach to the phenomena of genre, style, stylistics, composition, text and some others in music; the musicologist's dialogue with «musical time» is of great benefit to both: time opens its true addressee in the human personality - in the personal consciousness, finds ways of communicating with it, and the musicologist - defines new possibilities of forming cognitive reconciliations with the phenomenon of time.

135 Орлов Г. Структурная функция времени в музыке. (Исполнение и импровизация). Вопросы теории и эстетики музыки. Вып. 13. Л.: Музыка, 1974. C. 32.

136 Выготский Л. Педагогическая психология./ Под ред. В.В. Давыдова. М.: Педагогика, 1991. С. 281; 282. 


\section{CONCLUSIONS}

To conclude the study, it should be noted that the «great» common experience of human culture is, first of all, the experience of symbolic definition of reality, the creation of different types of symbolic tools for managing it, but the most important thing is the creation of one's own human semantic reality. This reality involves norms of thinking and behavior, certain types of lifestyle, a variety of experiences and emotional reactions; in other words, it involves certain ways and varieties of psychological modeling, the material of which is generously given by art.

Out of the various artistic forms, especially close to the personal senses, the personal psychological world of a man with his unique «interpretative time» is music. At every stage of its existence, music opens new sides of person's psychological experience, while shaping and transforming it. Studying the artistic content of music, its intentional semantic capabilities are equal to revealing the psychological history of mankind. But it requires special methodological efforts.

Our research makes it clear that for musicological cognition the necessary constituent races are intentionality, contextuality and responsibility, as well as integrativeness, aesthetic and psychological profundity. They point to the fundamental ethical importance of musicological cognition and assessment that are capable of cognitive isolation and methodological universalization. Thanks to these initial cognitive conditions, modern musicology is capable of new methodical and categorical interaction with the psychology of arts, the formation of a new system of cognitive criteria in common with the psychology of arts.

Talking about the new methodical and categorical unity of the psychology of arts and musicology, the works of L. Vygotsky, which, collectively, can be assessed as the foundation of modern psychology of consciousness and the theory of artistic meaning, are a necessary component. Vygotsky's teaching is a necessary factor in general humanitarian conception of man, in addressing issues of human existence in the world around him, that is, in his existential problems. The psychological concepts offered by this researcher, which make it possible to explore the artistic form, including music, should be 
regarded as broad «epistemological metaphors» that are effective at different stages of psychological and musicological cognition.

The actualization of the epistemological approach to the study of musical artifacts, together with the deepening of phenomenological and aesthetic positions, also allows to distinguish the noological approach - not only as a key and integrative, but also as the closest to the psychological semantic essence of artistic phenomena, especially musical language. The central category in this approach is the category of catharsis combined with the phenomena of artistic symbolics and with the discursive priorities of «other scientific symbolology».

The noological concept of catharsis offered in the monograph makes it clear that the complex symbolic meaning of aesthetic purification cannot be found only in tragedy. The catharsis is prepared by tragedy, but takes place outside it, one might say, even contrary to tragedy. It is no accident that its content is determined by such aesthetic categories as the Beautiful (Beauty), the Good, the Light, the Harmony, which oppose the catastrophic resolution of the tragedy. These categories are in themselves symbolic entities, which make them the subject of constant humanitarian disputes, and such disputes are fundamentally incomplete, because their subject is that which implies a semantic immensity and infinity. "The absolute is understood not "with the help" of the symbol, but "in" the symbol», as V. Frankl wrote ${ }^{137}$. Thanks to catharsis, the monotheme of tragedy becomes not a «monotheme of death», as suggested by L. Vygotsky, but a monotheme of immortality...

This cognitive position is reinforced by the study of N. Roerich's work «Living Ethics», in which there are no concepts directed to the «dark sides» of being - to death, the year, the corruptible, although the author resorts to semantic antithesis (Darkness - Light; Fear, Disbelief - Determination, Direction, and similar). Using paired concepts-images, Roerich narrows down the negative definitions, abandoning the possibility of tragedy preparation of catharsis, immediately giving it «bright» symbolics. Such symbolics is most consistent with the completeness of the value-aesthetic relation as the

${ }^{137}$ Франкл В. Человек в поисках смысла. М., 1990. С. 128. 
«relevant and beautiful» (according to G. Gadamer), in the broad cosmological meaning of the latter. The catharsis in Roerich's Poetics is the acceptance of cosmic Infinity as relevant and beautiful in that personal experience, the limits of which each individual sets for himself...

It is in this sense that catharsis becomes the leading aesthetic effect of musical action.

According to M. Bakhtin's observation, we have the right to behave freely about historical experience: to ask our own cultures our own questions, moreover, to find in their experience such questions that they did not even suspect. This is a broad form of cognitive psychological and artistic dialogue - such question-answering relationships that determine the structure of spiritual experience of people and seek a symbolic form of expression. If there was no symbolic openness of the spiritual content of each culture, then deaf walls would stand between the separate stages of human consciousness development.

The principal incompleteness, openness of the most important spiritual questions, to which the question of catharsis is related, is the key to their longevity. That is why the doctrine of L. Vygotsky and N. Roerich's «Living Ethics» and our study emerge as a kind of answer, at a tremendous distance, to the questions posed by ancient philosophy and to which many successors have been trying for centuries to answer, those, who inherit cognitive tradition of studying the semantic construction of human consciousness.

An important aspect of this tradition, as it is evidenced in this monograph, is the knowledge of the phenomenon of time and the predefined system of concepts. After all, the leading aspect of «human time» is the psychological, associated with the processes of comprehension of both the external life series, and the ways and methods of its reflection in the human mind. These prerequisites allow us to formulate certain approaches to musical time, noting that music is structured in sound and thus meaningful time insofar as it and above all - infuses its «manner and order» into a person's feelings and thoughts, bringing his consciousness to the sense, and the sense - to consciousness, carrying out the "secondary creative synthesis» of the emotional content of consciousness, due to the 
deepest need for transformation of «lower types of energy, into higher kinds ...» (L. Vygotsky).

Harmonization of methodical prolegomena of research with its categorical content suggests that the phenomenon of semantic consciousness remains the most fundamental for all levels of musicological psychology of arts, in fact, it initiates it.

The peculiar nature of musicological discourse arises from the reflection in it of the nature of musical assessment - in comparison with other cultural norms. Musical semantic positions are formed under the direct influence of the always positive setting of aesthetic comprehension (comprehension as an aesthetic phenomenon). Even all the objections (elimination - alienation) in the music are deeply positive; only the lack of implementation of its main cathartic idea can be negative. The latter in music (unlike other spheres of culture) clearly indicates its own holistic character with an emphasis on the ethical side.

Musicality as an in-depth psychological feature of music is subject only to the language of «other-scientific symbolology» (S. Averintsev), which does not belong definitively (like the senses of music) to any one type of humanitarian discourse, but is most important for the psychology of arts and can be explained within its conceptual system; it is most intended in aesthetic and psychological terms, pointing at the same time to the unity of psychological and aesthetic nominations when discussing music and to the symbolic origin and purpose of aesthetic attitude. Thus, musicological projections of the aesthetic and psychological approach of L. Vygotsky are also revealed. 


\section{SUMMARY}

The monograph combines and systematizes current musicological approaches to the subject area of psychology of arts, carried out by the author of this research over the last decades, allows to form a new musicological theory of psychology of arts and to offer this discipline (psychology of arts) as one of the leading directions of modern musicology.

Psychological foundations of semantic analysis in musicology are developed, in connection with which a synthesis of epistemological and semiological approaches in the study of the phenomena of sense and symbol is proposed. A holistic and integrated research methodology allows us to introduce categories that are common to musicology and the psychology of the arts, giving them systemic unity and orderliness.

Among them, the basic categories are spirituality, psychological reality, artifact, noology and noetic as the highest kind of semantic relation, musical sense, musical symbol, musical language, musicological meta-language, symbolology, musicological discourse and immanent logos of music, musical semantics, tragic, catharsis, time and space, text and content hypostasis.

Leading theoretical angles of the monograph are due to the need to isolate and explain the noetic (noological) universals of culture and the noetic dimensions of musical art. Concepts of memory, play, and love are deepened to illuminate their psychological functions; concepts of genre, style, and composition are positioned as noetic, while at the same time special musicologists, being included in the categorical sequence formed in the process of discussing the psychological properties of music.

Consideration of noetic antinomies in their relevance to the phenomenon of catharsis allows to determine the principles of creation and completion of a musical composition as an immanent logical system of music, acting at different stages of musical and linguistic realization of an artistic idea. In the context of musical creativity, this system emerges as a cathartic conventionality of a selfdialogue of music, based on the transitive features of a musical composition contexture, and at the same time corresponds to the main varieties of semantic dialogue. 
A special symbolological «other language» of N. Roerich's ethical doctrine is found, which raises the language of arts to the conceptual generalization of the mythological level and therefore provides a model of aesthetic and psychological meta-language.

To sum up, this monograph is a proposal to build a methodical and categorical system of musicological psychology of arts; it introduces a synthesis of the scientific and psychological problems that are most relevant to the current state of the humanitarian sciences and human consciousness. 


\section{REFERENCES}

1. Аверинцев С. Символ. С.С. Аверінцев. Софія-Логос. Словник. К.: Дух і Літера, 1999. С. 154-159.

2. Аверинцев С. Поэтика ранневизантийской литературы. М.: Coda, 1997. 342 c.

3. Аверинцев С. К уяснению смысла надписи над конхой центральной апсиды Софии Киевской. С.С. Аверінщев. СофіяЛогос. Словник. К.: Дух і Літера, 1999. С. 214-243.

4. Акопян Л. Анализ глубинной структуры музыкального текста. - М.: Практика, 1995. 256 с.

5. Алфёров А. Современность: два среза понятия. Информационный гуманитарный портал «Знание. Понимание. Умение». № 3. 2011. URL: http://zpu-journal.ru/e-zpu/2011/3/ Alferov_Modernity/

6. Арановский М. Музыкальный текст. Структура и свойства М.: Композитор, 1998. 343 с.

7. Аристотель. Поэтика (Об искусстве поэзии). М., 1957.

8. Артефакт. Артефакт культурный. Культурология. XX век. Словарь. Сост. статей А. Красноглазов, А. Флиер. Спб.: Университетская книга, 1997. С.44-46.

9. Бахтин М. Автор и герой в эстетической деятельности. М.М. Бахтин. Эстетика словесного творчества. 2-ое изд. Сост. С. Бочаров. Прим. С. Бочарова и С. Аверинцева. М.: Искусство, 1986. C. 9-191.

10.Бахтин М. К философии поступка. М.М. Бахтин. Работы 1920-х годов. К.: Наукова думка, 1994. С. 9-68.

11.Бахтин М. Искусство и ответственность. М.М. Бахтин. Эстетика словесного творчества. 2-е изд. Сост. С. Бочаров; прим. С. Бочарова и С. Аверинцева. М.: Искусство, 1986. С. 7-8.

12.Бахтин М. Проблема речевых жанров. М.М. Бахтин. Эстетика словесного творчества. 2-е изд. Сост. С. Бочаров; прим. С. Бочарова и С. Аверинцева. М.: Искусство, 1986. С. 254.

13.Бахтин М. Слово в романе. М.М. Бахтин. Bonpocbl литературы и эстетики. Исследования разных лет. М.: Художественная литература, 1775. С. 72-233. 
14.Бахтин М. Из предыстории романного слова. М.М. Бахтин. Вопросы литературы и эстетики. Исследования разных лет. М.: Художественная литература, 1975. С. 427.

15.Бахтин М. Эпос и роман. М.M. Бахтин. Bonросы литературы и эстетики. Исследования разных лет. М.: Художественная литература, 1975. С. 447-483.

16.Бахтин М. Формы времени и хронотопа в романе. Bonpocbl литературы и эстетики. Исследования разных лет. М.: Художественная литература, 1975. С. 234-407.

17.Бахтин М. Проблемы поэтики Достоевского. М.: Художественная литература, 1975. С. 6-71.

18.Бахтин М. Проблема содержания, материала и формы в словесном художественном творчестве. М. Бахтин. Boпросы литературы и эстетики. Исследования разных лет. С. 6-71.

19.Бахтин М. Проблема текста в лингвистике, филологии и других гуманитарных науках. М. Бахтин. Эстетика словесного творчества. М.: Искусство, 1986. С. 297-325.

20.Бердяев Н. Самопознание. Сочинения. М.: ЗАО Изд-во ЄКСМО-Пресс; Харьков: Изд-во Фолио, 1999. 624 с.

21.Бобровский В. О драматургии скрябиновских сочинений. В. Бобровский. Избранные статьи и исследования. М.: Музыка, 1990. С. $148-158$

22.Бонфельд М. Музыка. Язык. Речь. Мышление. Опыт системного исследования музыкального искусства. СПб., 2006. $648 \mathrm{c.}$

23.Босенко А. Власть времени, или Оставьте М. Бахтина в покое. М.М. Бахтин и перспективы гуманитарных наук: Материалы науч. конферениии. Витебск, 1994. С. 83-85.

24.Варунц В. Музыкальный неоклассицизм. М.: Музыка, 1988. $80 \mathrm{c}$.

25.Виппер Р. История древнего мира. В. Ю. Виппер. История древнего мира; А.А. Васильев. История средних веков. М.: Изд-во «Республика», 1993. С. 14-244.

26.Выготский Л. История развития высших психических функций. Л.С. Выготский. Собр. соч. в 6-ти томах. Т. 3. М.: Педагогика, 1983. С. 5-328.

27.Выготский Л. Психология искусства. М.: Искусство, 1968. $576 \mathrm{c}$. 
28.Выготский Л. Педагогическая психология. Под ред. В.В. Давыдова. М.: Педагогика, 1991. 480 с.

29.Выготский Л. Психика, сознание, бессознательное. Психология сознания. СПб.: Питер, 2001. С. 31-46.

30.Выготский Л. Лекции по психологии. Л.С. Выготский. Собр. соч. в 6-ти томах. Т. 2. Под общей ред. В. Давыдова. М.: Педагогика, 1982. С. 363-485.

31.Выготский Л. Проблема сознания. Л.С. Выготский Собр. соч. в 6-ти томах. Т. 1. Под ред. А. Лурия, М. Ярошевского, М.: Педагогика, 1982. С. 156-167.

32.Выготский Л. Инструментальный метод в психологии. Л.С. Выготский. Собр. соч. в 6-ти томах. Т. 1. М.: Педагогика, 1982. C. 103-108.

33.Выготский Л. О психологических системах. Л.С. Выготский. Собр. соч. в 6-ти томах. Т.1. М.: Педагогика, 1982. C. 109-131.

34.Выготский Л. Проблемы общей психологии. Л.С. Выготский. Собр. соч. в 6-ти томах. Т. 2. Под общей ред. В. Давыдова. М.: Педагогика, 1982. С. 362-490.

35.Гадамер Х.-Г. Семантика и герменевтика. Актуальность прекрасного: Пер. с нем. М.: Искусство, 1991. С. 60-71.

36.Гадамер Х.-Г. Язык и понимание. Актуальность прекрасного: Пер. с нем. М.: Искусство,1991. С. 43-59.

37.Гадамер Х.- Г. Текст и интерпретация. Герменевтика и деконструкиия. Под ред. Штегмайера В., Франка Х., Маркова Б. СПб., 1999. С. 202-242.

38.Гаспаров Б. Язык, память, образ. Лингвистика языкового существования. М.: Новое литературное обозрение, 1996. 352 с.

39.Герасимова-Персидська Н. Нове в музичному хронотопі кінця тисячоліття. Українське музикознавство. Науковометодичний збірник. Вип. 28. Музична украӥністика в контексті світової культури. К., 1998. С. 32-47.

40.Герасимова-Персидская Н. О восприятии музыки и постижении смысла. Науковий вісник НМАУ ім. П. І. Чайковського. Вип. 60: Теоретичні та практичні аспекти музичного смислоутворення. 3б. статей. К., 2006. С. 6.

41.Герасимова-Персидская Н. Целостность как универсалия и еe проявление в музыке. Науковий вісник НМАУ 
ім. П. І. Чайковського. Вип. 51: Питання організації художньої цілісності музичного твору. 3б. статей. К., 2005. С. 3-8.

42.Гессе Г. Игра в бисер. М.: Художественная литература, 1969. $418 \mathrm{c}$.

43.Гуманистическая и трансперсональная психология: Хрестоматия. Сост. К.В. Сельчёнок. Минск - Москва: Харвест - Аст, 2000. 592 с.

44.Гуревич П. Игра. Культурология. ХХ век. Словарь. СПб.: Университетская книга, 1997. С. 133-135.

45.Гуссерль Э. Избранные работы: сост. В. А. Куренной. М.: Издательский дом «Территория будущего», 2005. 464 с.

46.Задерацкий В. Музична форма. В 2-х вип. Вып.1: Підручник для спеціалізованих факультетів вищих музичних навчальних закладів. М.: Музика, 1995. 544 с.

47.Зинченко В. Миры сознания и структура сознания. URL: http://development2005.narod.ru/books/zin.htm

48.Зинченко В., Моргунов Е. Поступок и целостность человека по М.М. Бахтину. В. Зинченко, E. Моргунов. Человек развиваюшийся: Очерки русской психологии. Гл. 2: Культурные традиции российской психологии. М.: 1994. С. 57-61.

49.Камчатнов А. М. А. А. Потебня и А. Ф. Лосев о внутренней форме слова. Русский филологический вестник. 1998. № 1-2. C. 16. URL: https://sites.google.com/site/kamchatnoff/ Дата доступа: 15.10 .2015$.

50.Кирилюк А. Универсалии культуры и семиотика дискурса. Миф. Одесса: Изд. Дом «Рось», 1996. 142 с.

51.Кирнарская Д. Психология музыкальной деятельности. Теория и практика. М, 2003. 368 с.

52.Котляревський I. Музично-теоретична україністика. Украйнське музикознавство. Науково-методичний збірник. Вип. 28. Музична україністика в контексті світової культури. К., 1998. С. 9-12.

53.Котляревський I. Пріоритетність як фактор розвитку музикознавства / І. Котляревський. Теоретичні та практичні питання культурологї: Украӥнське музикознавство на зламі століть. Збірник наукових статей. Мелітополь: «Сана», 2002. Вип. IX. С. 3-10. 
54.Кучеренко В., Петренко В., Россохин А. Измененные состояния сознания: психологический анализ. Психология сознания. СПб.: Питер, 2001. С. 403-411.

55.Кушмина Р. Язык и музыка как смыслообразующие звуковые формы культуры. Дис. ...канд. философ. наук: спец. 24.00.01 - теория и история культуры. Казань, 2004. 167 с.

56.Леонтьев Д. Психология смысла: природа, строение и динамика смысловой реальности. 3-е изд., доп. М.: Смысл, 2007. $511 \mathrm{c}$.

57.Леонтьев А. Деятельность. Сознание. Личность. Психология сознания. СПб.: Питер, 2001. С. 72-81.

58. Лихачёв Д. Развитие русской литературы X - XVII века. Л.: Наука, 1973. 254 с.

59.Лосев А. Музыка как предмет логики. А. Ф. Лосев. Форма. Стиль. Выражение. Сост. А.А. Тахо-Годи. М.: Мысль, 1995. C. $405-602$

60.Лосев А. Форма, стиль, выражение. М.: Мысль, 1995. $940 \mathrm{c}$.

61.Лотман Ю. Семиосфера. Культура и взрыв. Внутри мыслящих миров: Статьи. Исследования. Заметки (1968-1972). СПБ.: Искусство, 2000. 704 с.

62.Лотман Ю. Проблема «обучения культуре». Труды по знаковым системам V. Учёные запискм Тартусского гос. университета. Вып. 284. Тарту: 1971. С. 167-177.

63.Мартынов В. Время и пространство как факторы музыкального формообразования. Психология художественного творчества. Минск: Харвест, 2003. С. 130-144.

64.Маслоу А. Дальние пределы человеческой психики. Пер. с англ. А. М. Татлььбаевой. Научи, ред., вступ. статья и коммент. Н. Н. Акулиной. СПб.: Евразия, 1999. 432 с.

65. Маслоу А. Мотивация и личность. СПб.: Евразия, 1999. $478 \mathrm{c}$.

66. Матецкая А.В. Социология культуры. учебное пособие. 2006. $260 \mathrm{c}$.

67.Назайкинский Е. Логика музыкальной композиции. М. : Музыка, 1982. 319 с. 
68. Орлов Г. Структурная функция времени в музыке. (Исполнение и импровизация). Bопросы теории и эстетики музыки. Вып. 13. Л.: Музыка, 1974. С. 32-57.

69. Орлов Г. Время и пространство музыки. Проблемы музыкальной науки. Сб. статей. Вып. 1. М.: Всесоюзное изд-во Советский композитор, 1972. С. 358-394.

70. Петренко В. Проблемы значения. Психосемантика сознания. Психология сознания. СПб.: Питер, 2001. С. 169-182.

71.Петровский И. Феномен Борхеса. Х.Л. Борхес. Письмена бога. Сост., автор вступительной статьи и прим. И. Петровский. М.: Республика, 1994. С. 5-24.

72.Пигалев А. Время культуры. Культурология. ХX век. Словарь. Санкт-Петербург: Университетская книга, 1997. C. $80-85$.

73.Рерих Н. Живая этика. Избранное. М., 1992. 414 с.

74.Роменець В., Маноха I. Історія психології XX століття: Навч. посібник. Вст. ст. В.О. Шатенка, Т.М. Титаренка. К.: Либідь, 1998. 992 с.

75.Рубинштейн С. О сознании. Психология сознания. СПб.: Питер, 2001. С. 47-55.

76.Руднев В. Словарь культуры ХХ века. М. : Аграф, 1997. $384 \mathrm{c}$.

77.Савицька Н. Вікові аспекти композиторської життєтворчості. Дис. ...докт. мистецтвознавства; спец.: 17.00.03 - музичне мистецтво. Київ, 2010. 385 с.

78.Садецкий А. Открытое слово. Высказывания М.М. Бахтина в свете его металингвистической теории. М.: Российский государственный гуманитарный университет, 1997. 107 с.

79.Савенко С. К вопросу о единстве стиля Стравинского. И. Стравинский. Статьи и исследования. М.: Музыка, 1973. C. 276-301.

80.Савенко С. Позднее творчество И. Стравинского. К проблеме единства стиля. Из истории русской и советской музыки. Вып. 2. М.: Музыка, 1976. С. 243-257.

81.Самойленко А. Культурологическая концепция диалога М. Бахтина и методологические проблемы музыкознания. Культурологічна трансформація мистецьької освіти та 
актуальні питання творчої діяльності музиканта в сучасній Україні. Збірник наукових праць. К., 1998. С. 21-37.

82.Самойленко А. Музыковедение и методология гуманитарного знания. Проблема диалога. Одесса: Астропринт, 2002. 244 c.

83.Степанов Ю. Семиотика. М.: Наука, 1971. 168 с.

84.Суханцева В. Категория времени в музыкальной культуре. К.: Лыбидь, 1990. 184 с.

85.Тараева Г. Семантика музыкального языка: конвенции, традиции, интерпретации. Дис. ...докт. искусствоведения: спец. 17.00.02 - музыкальное искусство. Ростов-на-Дону, 2013. 411 с.

86. Таранов П. Анатомия мудрости. 120 философов: В 2-х тт. Симферополь: Таврия, 1996. Т. 1. 624 с.

87.Тарасти Э. Музыка как знак и как процесс. Homo musicus. Альманах музыкальной психологии. М.: 1999. С. 61-78.

88.Уайт Л.А. Наука про культуру. Антологія досліджень культури. Т.1. Інтерпретації культури. Спб.: Університетська книга, 1997. С. 141-156.

89.Філософський енциклопедичний словник. Гол. ред.: В. І. Шинкарук; ред. кол.: С. К. Бистрицький, М. А. Булатов, A. Т. Муратов та інші. К.: Абрис, 2002. 742 с.

90.Флоренский П. Иконостас. Павел Флоренский. Християнство и культура. М.: Фолио, 2001. С. 521-626.

91.Флоренский П. Из богословского наследия. Богословские труды. Т. XVII. M., 1977. С. 85-248.

92.Франкл В. Человек в поисках смысла: Пер. с англ. и нем. Bступ. cm. А. Леонтьева. М.: Прогресс, 1990. 367 с.

93. Фромм Э. Человек для себя. М.: АСТ; Мн.: Харвест, 2006. $352 \mathrm{c}$.

94. Хейзинга Й. Homo ludens В тени завтрашнего дня: Пер с нидерланд. М., Прогресс - Академия, 1992. 464 с.

95. Херсонский Б. Глубинная психология. Справочное издание. Одесса: Астропринт, 1998. 192 с.

96. Холопова В., Рестаньо Э. София Губайдулина: Монографическое исследование. Интервью с Губайдулиной. М.: Композитор, 1996. 360 с.

97. Холопов Ю. Изменяющееся и неизменное в эволюции музыкального мышления. Проблемы традиции и новаторства в 
современной музыке. М.: Сов. композитор, 1982. С. 52-104. URL: http://www.kholopov.ru/izm/

98. Хоффман И. Активная пам'ять. Экспериментальные исследования и теория человеческой памяти: Пер. с нем. К.М. Шоломия. М.: Прогресс, 1986. 309 с.

99. Чигарева Е. Оперы Моцарта в контексте культуры его времени. Художественная индивидуальность. Семантика. М.: УРСС, 2000. $279 \mathrm{c}$.

100. Эйкен Р. Смысл и ценность жизни. Пер. $c$ нем. М. М. Тареева. М.: ЭЛИА-АРТО, 2008. 80 с.

101. Эко У. Отсутствующая структура. Введение в семиологию. СПб.: ТОО ТК «Петрополис», 1998. 432 с.

102. Эко У. Поэтика открытого произведения. У. Эко. Открытое произведение. Форма и неопределенность в современной поэтике. Санкт-Петербург: Symposium, 2006. C. 67-104.

103. Dialogue and Dialogism. Rethinking Bakhtin: Extensions and Challenges; eds. Gary Saul Morson and Caryl Emerson. Evanston: Northwestern University Press, 1989. P. 105-114.

104. Wertsch J. V. The significance of dialogue in Vygotsky's account of social, egocentric, and inner speech // Contemporary Educational Psychology, 5, 1980. P. 150-162.

105. Shotter J. Bakhtin and Vygotsky: internalization as a boundary phenomenon. New Ideas in Psychology, 11, 1993. P. 379-390.

106. Shotter J. Harre, Vygotsky, Bakhtin, Vico, Wittgenstein: conversational realities and academic discourses. Journal for the Theory of Social Behavior, 23, 1993. P. 459-482.

107. Shotter J. Vygotsky's psychology: activity in the developmental zone. New Ideas in Psychology, 7, 1989. P. 185-204.

108. Shotter J. Vygotsky: the social negotiation of semiotic mediation. New Ideas in Psychology, 11, 1993. P. 61-75.

109. Tarasti E. Music as sign and process. Analytica. Stakholen, 1985. P. 97-115. 
NOTES 
Publishing house "Liha-Pres"

9 Kastelivka str., Lviv, 79012, Ukraine 44 Lubicka str., Toruń, 87-100, Poland

Printed by the publishing house "Liha-Pres"

Passed for printing: February 14, 2020 . A run of 150 copies. 